\title{
REVIEW OF MITES (ACARI) ASSOCIATED WITH THE EUROPEAN SPRUCE BARK BEETLE, IPS TYPOGRAPHUS (COLEOPTERA: CURCULIONIDAE: SCOLYTINAE) IN ASIAN RUSSIA
}

\author{
Alexander A. Khaustovi*, Pavel B. Klimovi,2, Viacheslav A. Trach ${ }^{3,4}$, Andrei N. Bobylev1, \\ Vladimir M. Salavatulin', Vladimir A. Khaustov' ${ }^{1}$ and Andrei V. Tolstikov ${ }^{1}$
}

\author{
${ }^{1}$ Tyumen State University, Tyumen, Russia \\ ${ }^{2}$ Department of Ecology and Evolutionary Biology, Museum of Zoology, University of \\ Michigan, Ann Arbor, USA \\ ${ }^{3}$ Odessa I.I. Mechnikov National University, Odessa, Ukraine \\ ${ }^{4}$ Ukrainian I.I. Mechnikov Anti-Plague Research Institute, Odessa, Ukraine \\ *corresponding author; e-mail: alex1973khaustov@gmail.com
}

\begin{abstract}
A total of 68 mite species were collected on Ips typographus and in their galleries in Siberia and in the Far East of Russia: Cercoleipus kuznetsovi (Cercomegistidae), Pleuronectocelaeno barbara, P. japonica (Celaenopsidae), Uroobovella ipidis (Urodinychidae), Trichouropoda polytricha, T. karawaiewi, T. structura (Trematuridae), Schizosthetus sp. (Parasitidae), Dendrolaelaps (Ipidodendrolaelaps) quadrisetus, Dendrolaelaps (Insectolaelaps) pini, Dendrolaelaps (Apophyseodendrolaelaps) disetosimilis (Digamasellidae), Macrocheles (s. str.) ivanovi (Macrochelidae), Gamasellodes tatricus (Ascidae), Proctolaelaps fiseri, $P$. hystricoides, $P$. juradeus (Melicharidae), Ereynetes (Huntereynetes) sp. (Ereynetidae), Mexecheles virginiensis (Cheyletidae), Dolichocybe sibiriensis (Dolichocybidae), Pyemotes sp. (Pyemotidae), Aethiophenax ipidarius (Acarophenacidae), Microdispodides moseri, Elattoma crossi (Pygmephoridae), Coleopygmephorus bogenschutzi, C. hylophilus, C. typographus (Neopygmephoridae), Scutacarus pseudoplurisetus, S. scolyti, S. muscocicola, S. palustris (Scutacaridae), Iponemus gaebleri gaebleri, Tarsonemus striatus, T. (Schaarschmidtia) bistridentati, T. typographi, Heterotarsonemus lindquisti (Tarsonemidae), Siculobata (Paraleius) leontonycha (Scheloribatidae), Acarus sp., Boletoglyphus boletophagi, Forcellinia wasmanni, Ipsoglyphus bochkovi, Kuzinia laevis, Naiadacarus sp., Schwiebea sp. eurynympha-group [punctate dorsum], Sch. sp. eurynympha-group [small, unsclerotized, 1a, 3a filiform], Sch. nesbitti, Sch. nova, Sch. sp.1 nova-group [two tibial setae, regular attachment organ], Sch. sp. nova-group [two tibial setae, wide attachment organ], Sch. sp. nova-group [granulate dorsum, short legs III-IV], Sch. scheucherae, Thyreophagus corticalis, Th. entomophagus, Th. aff. odyneri, Tyrophagus putrescentiae (Acaridae), Divilia aff. occidentalis, D. sp., Hemisarcoptes sp., Nanacarus sp.1, N. sp.2, Superioropus huronmontanus (Hemisarcoptidae), Parawinterschmidtia kneissli, Saproglyphus aff. hagensis, S. waldorfae (Winterschmidtiidae), Histiostoma ovalis, H. piceae, H. pini, Probonomoia pini, P. sibirica (Histiostomatidae).

The following taxa are recorded for the first time: for the Palaearctic-Superioropus huronmontanus (genus and species); for Russia-Pleuronectocelaeno japonica, Trichouropoda karawaiewi, Dendrolaelaps pini, Gamasellodes tatricus, Scutacarus palustris, Tarsonemus typographi, Heterotarsonemus lindquisti, Hemisarcoptes, Saproglyphus waldorfae, Naiadacarus, Schwiebea nesbitti, Histiostoma pini, and $H$. ovalis. Of them, 60 species were collected by catching beetles with pheromone traps and examining them for phoretic mites.

We provide information on the current distribution, host association, and biology of these mites. In this article, we also discuss the following information, which we have documented: our biological observations of mites in the beetles' galleries, abundance of phoretic mites on hosts, as well as specific sites where they occur. To facilitate morphological diagnostics, common mite species were illustrated using a Scanning Electron Microscope (SEM), as well as light microscopy.
\end{abstract}

KEY WORDS: Acarina, phoresy, bark beetle, SEM photographs.

DOI: 10.21684/0132-8077-2018-26-1-3-79

\section{INTRODUCTION}

Many mites (Acari) are known to be associated with various bark beetles (Coleoptera: Curculionidae, Scolytinae) (Lindquist 1970a). They include predators, preying on bark beetle eggs and larvae, nematodes, and other mites, which inhabit bark beetle galleries. This group of mites also includes myco- and saprophagous mites, as well as parasitoids of bark beetle eggs and other beetle instars (Hofstetter et al. 2015). Most mites that inhabit bark beetle galleries use adult beetles for phoresy (Lindquist 1970a). The association of mite communities to particular bark beetle species is studied only in the cases of several economically important pests. They include: Dendroctonus fron- talis in North and Central America (Kinn and Swanston 1976; Moser and Roton 1971; Stephen and Kinn 1980); Ips typographus, I. sexdentatus, Pytyocteines spp, Scolytus multistriatus, S. pygmaeus in Europe (Čejka and Holuša 2014; Gwiazdowicz et al. 2011, 2012, 2015; Lieutier 1978; Moraza et al. 2013; Moser and Bogenschütz 1984; Moser et al. 1989; Penttinen et al. 2013; Pernek et al. 2008, 2012; Takov et al. 2009; Vrabec et al. 2012); and Ips typographus japonicus in Japan (Moser et al. 1997).

The widely distributed European spruce bark beetle, Ips typographus Linnaeus, 1758 (Coleoptera: Curculionidae: Scolytinae), is one of the most 
economically significant pests in the Palaearctic. Although it infests mainly spruce (Picea spp.), this beetle also occurs on other conifers, such as Pinus spp. and Abies spp. (Maslov 2010). Phoretic mites occurring on I. typographus have been the subjects of many studies using different sampling techniques. Kiełczewski et al. (1983) reported about 25 mite species collected manually in Poland. Moser and Bogenschütz (1984) recorded and provided a key to 32 species collected by pheromone traps in Germany. Moser et al. (1989) listed 24 mite species collected by pheromone traps in Sweden. Penttinen et al. (2013) recorded 33 mite species from pheromone traps in Finland and published their SEM micrographs. Moser et al. (1997) recorded 12 species of phoretic mites occuring on I. typographus japonicus, collected by Borregaard drain-pipe traps in Japan. Gwiazdowicz et al. (2011, 2012, 2015) studied mesostigmatic mites associated with I. typographus in Poland using Borregard pipe traps. Vrabec et al. (2012) and Čejka and Holuša (2014) also studied mesostigmatic mites in Slovakia (collected manually) and the Czech Republic (collected with pheromone traps), respectively. Wirth et al. (2016) compared mite communities associated with I. typographus and I. cembrae in Croatia (manual sampling in beetles' galleries). Mites associated with Ips typographus in Russia are poorly studied. Redikortzev (1947) described Pediculoides ipidarius in northwestern Russia. Maslov and Matusevich (2008) reported about eight mite species from European Russia. They also provided information about mortality of bark beetle eggs destroyed by Dendrolaelaps quadrisetus. Khaustov (2017a, 2017b, 2017c) and Trach and Khaustov (2017a, b) described several new species and provided new records of heterostigmatic and mesostigmatic mites in Western Siberia, which were collected by pheromone traps as well as in beetle galleries.

During our study of mites, associated with bark beetles in Asian Russia, we recovered 68 species of mites that were phoretic on or inhabited the galleries of the bark beetle Ips typographus. The aim of this paper is to document mite-beetle associations and provide diagnostic illustrations of the most common species.

\section{MATERIAL AND METHODS}

A total of 13,451 specimens of the European spruce bark beetle, Ips typographus were collected in the vicinity of settlement Uspenka, Tyumen Re- gion, Tyumen District, Russia, $57^{\circ} 04^{\prime} \mathrm{N}, 65^{\circ} 04^{\prime} \mathrm{E}$. The beetles were collected in May-June 2017 using five flight intercept pheromone traps "Barrier-500" (Pheromone ltd, Moscow, Russia). The collected bark beetles were placed into vials containing $96 \%$ ethanol. Then, the beetle specimens and alcohol sediments from the vials were inspected for phoretic mites using a dissecting microscope Discovery V8 (Carl Zeiss, Germany). Galleries of Ips typographus from various localities were also examined. For SEM microscopy, live beetles were frozen at $-25^{\circ} \mathrm{C}$. Images of beetles with phoretic mites were obtained using a JEOL-JSM-6510LV SEM microscope. The beetles were not dusted. Mites were mounted in Hoyer's medium (Walter and Krantz 2009). The morphology of mites was studied using a Carl Zeiss Axio Imager A2 microscope with DIC and phase-contrast objectives. Photomicrographs were taken with AxioCam 506 color and Hitachi KP-HD20A digital cameras. The studied material was subsequently deposited to the mite collection of the Tyumen State University Museum of Zoology, Tyumen, Russia.

\section{RESULTS}

\section{Order Mesostigmata \\ Infraorder Cercomegistina \\ Family Cercomegistidae}

\section{Cercoleipus kuznetsovi Khaustov, 1997}

(Figs. 1A, B, 42A)

Cercoleipus kuznetsovi was described based on adult mites recovered from the galleries of Ips sexdentatus, located under the bark of a Crimean pine (Pinus nigra pallasiana), in Crimea (Khaustov 1997). Later, C. kuznetsovi has been recorded in the galleries of Ips mannsfeldi and Orthotomicus erosus, located under the bark of an Eldar pine (Pinus brutia eldarica), in Iran (Ahadiyat et al. 2011; Ostovan et al. 2010). Trach and Khaustov (2017a) gave a complete redescription of all instars of this species based on the material from the galleries of Ips sexdentatus and Orthotomicus sp., associated with Crimean pine in Crimea. The redescription mentioned above was also based on material from the galleries of Ips typographus located on a Siberian spruce (Picea obovata), in Western Siberia.

Only adult stages of this mite species are phoretic (Fig. 42A). The development of juvenile stages occurs in bark beetle galleries. During phoresy, males and females of C. kuznetsovi freely 


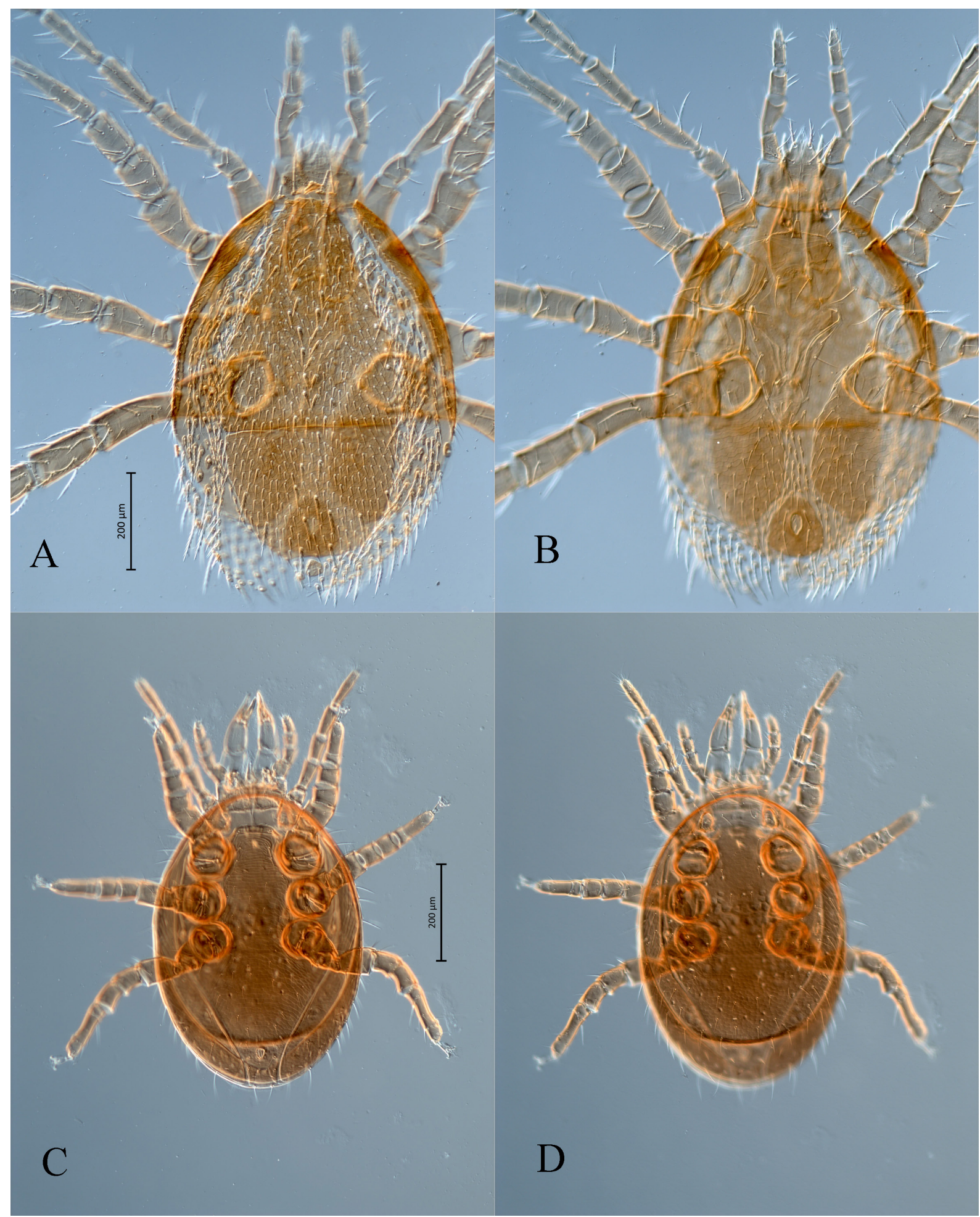

Fig. 1. A, B-Cercoleipus kuznetsovi, female, dorsal and ventral views, respectively, C, D-Pleuronectocelaeno barbara, male, ventral and dorsal views, respectively.

move around the host beetle body without attaching to specific sites (Trach and Khaustov 2017a). All our records of this species originated from either beetle hosts or their galleries; no specimens were collected by pheromone traps.
Material examined. Two females, 2 males, 2 deutonymphs, 7 protonymphs, 1 larva, Russia, Tyumen Region, Tyumen District, vicinity of settlement Uspenka, $57^{\circ} 04^{\prime} \mathrm{N}, 65^{\circ} 04^{\prime} \mathrm{E}$, on Ips typographus and in its galleries under the bark of Picea obovata, 5 July 2016, coll. A.A. Khaustov. 
A.A. Khaustov, P.B. Klimov, V.A. Trach et al.

Infraorder Antennophorina

Family Celaenopsidae

\section{Pleuronectocelaeno barbara Athias-Henriot, 1959}

(Figs. 1C, D)

This predatory species is distributed in Algeria (Athias-Henriot 1959), North America (Kinn 1968; Moser and Roton 1971), Sweden (Kinn 1991; Moser et al. 1989; Sellnick 1951), Denmark, Norway (Kinn 1991), Crimea (Khaustov 1997), Croatia (Pernek et al. 2008, 2012), Italy (Plumari 2008), Iran (Ahadiyat et al. 2012) and Western Siberia (Khaustov et al. 2016). It is associated with many bark beetle species: Ips acuminatus (Sellnick 1951), Pityogenes sp. (Kinn 1991), Tomicus minor, Hylurgops palliatus, Pityogenes bistridentatus, Taphrorychus bicolor (Khaustov 1997), Pityocteines curvidens (Pernek et al. 2008, 2012), Crypturgus cinereus (Plumari 2008), Orthotomicus erosus (Ahadiyat et al. 2011), Dendroctonus frontalis, Ips avulsus, I. calligraphus, I. confusus, I. grandicollis, I. crebricollis, I. typographus, Orthotomicus sabinianae (Hofstetter et al. 2015), and Pityogenes chalcographus (Khaustov et al. 2016).

Only adults are phoretic, while juvenile stages develop in the galleries of bark beetles. We did not observe phoresy of P. barbara on I. typographus. Probably, this species got into the galleries of $I$. typographus from the galleries of other co-occurring bark beetle species, e.g., Pityogenes chalcographus.

Material examined. One female, 2 males, Russia, Tyumen Region, Tyumen District, vicinity of settlement Uspenka, $57^{\circ} 04^{\prime} \mathrm{N}, 65^{\circ} 04^{\prime} \mathrm{E}, 3 \mathrm{Au}-$ gust 2016, in the galleries of Ips typographus under bark of Siberian spruce (Picea obovata), coll. A.A. Khaustov.

\section{Pleuronectocelaeno japonica Kinn, 1991}

(Figs. 2A, B)

Pleuronectocelaeno japonica was described from Ips typographus japonicus, recovered from pheromone traps in Japan (Kinn 1991; Moser et al. 1997). This mite also occurs on bark beetles Pityokteines curvidens that live on Silver firs (Abies alba) in Croatia (Pernek et al. 2008).

Ours is the first record of P. japonica in Russia. Previously, $P$. japonica has never been reported in association with Ips typographus typographus.

Material examined. One male, Russia, Primorsky Krai, Lazo, 4330'04.6" N, 13334'47.1" E,
28 August 2016, in the galleries of Ips typographus under the bark of a Korean spruce Picea koraiensis, coll. A.A. Khaustov.

\section{Infraorder Uropodina \\ Family Urodinychidae}

\section{Uroobovella ipidis (Vitzthum, 1923)}

(Figs. 2C, D, 37F, 38A-D, 39A)

This species is known from Austria, Germany, Poland, Croatia, Russia, Lebanon, Slovakia (Mašán 2001), Sweden (Moser et al. 1989), Czech Republic (Čejka and Holuša 2014), Bulgaria (Takov et al. 2009) and Spain (Fernández et al. 2013). Deutonymphs of this species are phoretic on various bark beetles: Ips typographus (Čejka and Holuša 2014; Feketeová 2011; Gwiazdowicz et al. 2012; Moser and Bogenschütz 1984; Moser et al. 1989; Takov et al. 2009; Vrabec et al. 2012), Ips sexdentatus (Fernández et al. 2013), Hylastes cunicularius (Kršlak et al. 2010), Pityocteines curvidens, P. spinidens, $P$. worontzowi (Pernek et al. 2008, 2012), and Pityogenes chalcographus (Khaustov et al. 2016; Zach et al. 2016).

In our study, this was one of the most abundant species. It is usually phoretic on elytral declivities and the ventral thoraxes of coleopteran hosts (Figs. 38A-D, 39A).

Material examined: 893 deutonymphs, Russia, Tyumen Region, Tyumen District, vicinity of settlement Uspenka, $57^{\circ} 04^{\prime} \mathrm{N}, 65^{\circ} 04^{\prime} \mathrm{E}$, in alcohol sediments containing numerous specimens of European spruce bark beetle Ips typographus collected by pheromone traps, 22 May 2017, coll. A.A. Khaustov; 1,009 deutonymphs, same locality, 28 May 2017; 656 deutonymphs, same locality, 5 June 2017; 117 deutonymphs, same locality, 14 June 2017; 54 deutonymphs, same locality, 16 June 2017.

\section{Family Trematuridae \\ Trichouropoda polytricha (Vitzthum, 1923)}

(Fig. 3A, B, 38A)

This species is known from Germany, the Czech Republic, Slovakia, Turkmenistan (Mašán 2001), Sweden (Moser et al. 1989), Austria (Kofler and Schmölzer 2000); Poland (Gwiazdowicz and Gutowski 2012), Slovenia (Moraza et al. 2013), Finland (Penttinen et al. 2013), Spain (Fernández et al. 2013), Switzerland, Turkey, 


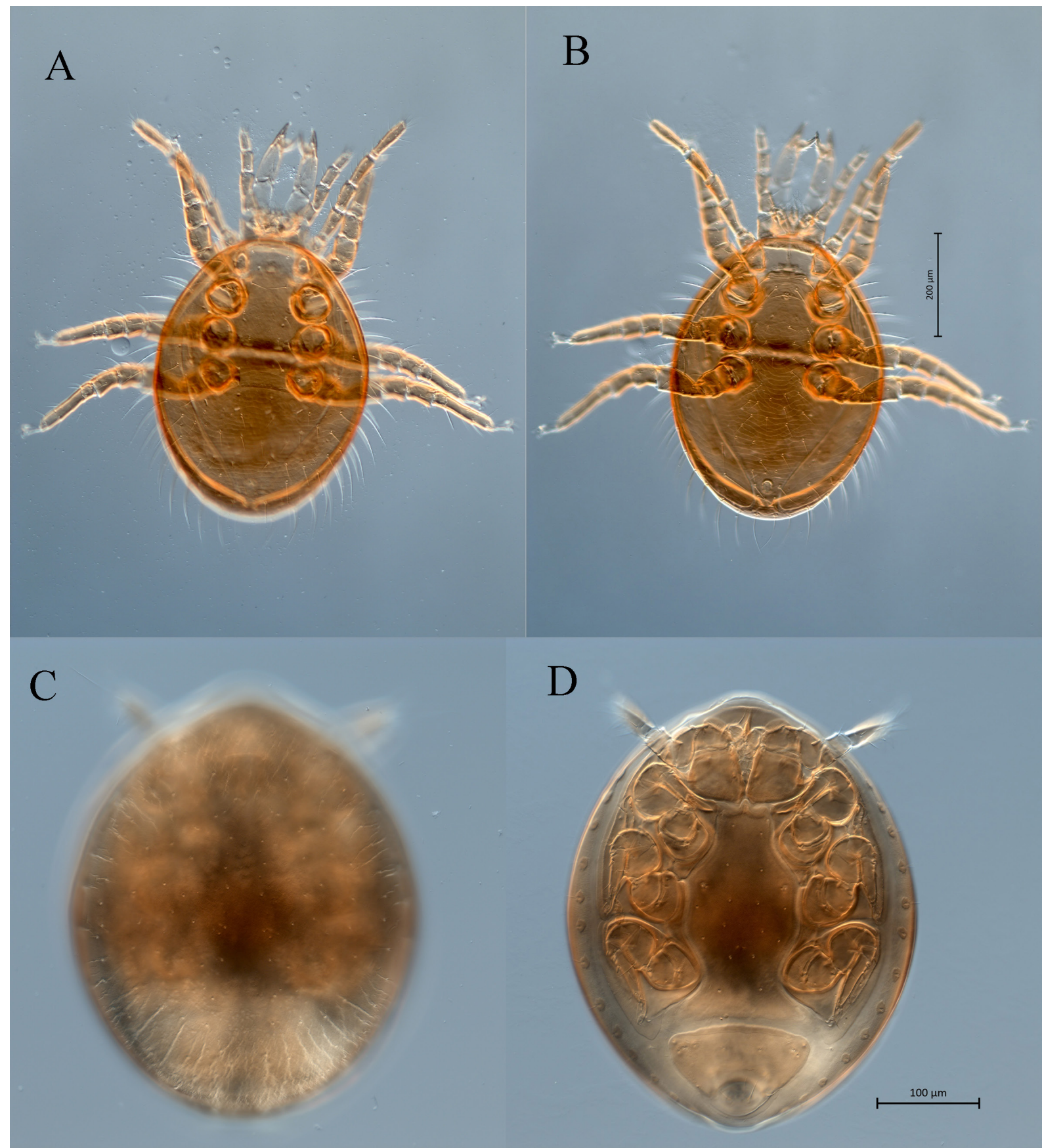

Fig. 2. A, B-Pleuronectocelaeno japonica, male, dorsal and ventral views, respectively, C, D-Uroobovella ipidis, deutonymph, dorsal and ventral views, respectively.

Canada, USA (Knee et al. 2013), Mexico (Chaires-Grijalva et al. 2013), Bulgaria (Takov et al. 2009) and Russia (Khaustov et al. 2016). Deutonymphs of this species are phoretic on various bark beetles: Ips typographus (Čejka and Holuša 2014; Feketeová 2011; Fernández et al. 2013; Gwiazdowicz and Gutowski 2012; Gwiazdowicz et al. 2011; Knee et al. 2013; Moser and Bogenschütz 1984; Moser et al. 1989; Penttinen et al. 2013; Takov et al. 2009; Vrabec et al. 2012), Ips sexdentatus (Fernández et al. 2013), Hylastes cunicularius (Kršlak et al. 2010), Dryocoetes autographus, Hylurgors palliatus, Ips amitinus, I. cembrae, I. hauseri, I. pilifrons utahensis, I. woodi, I. montanus, I. perturbatus, I. hunteri, I. borealis, Pityogenes chalcographus (Khaustov et al. 2016; Knee et al. 2013), and Dendroctonus rhizophagus (Chaires-Grijalva et al. 2013).

In our study, T. polytricha was one of the most abundant species (Table 1). It is usually phoretic on elytral declivities of hosts (Figs. 38A). 


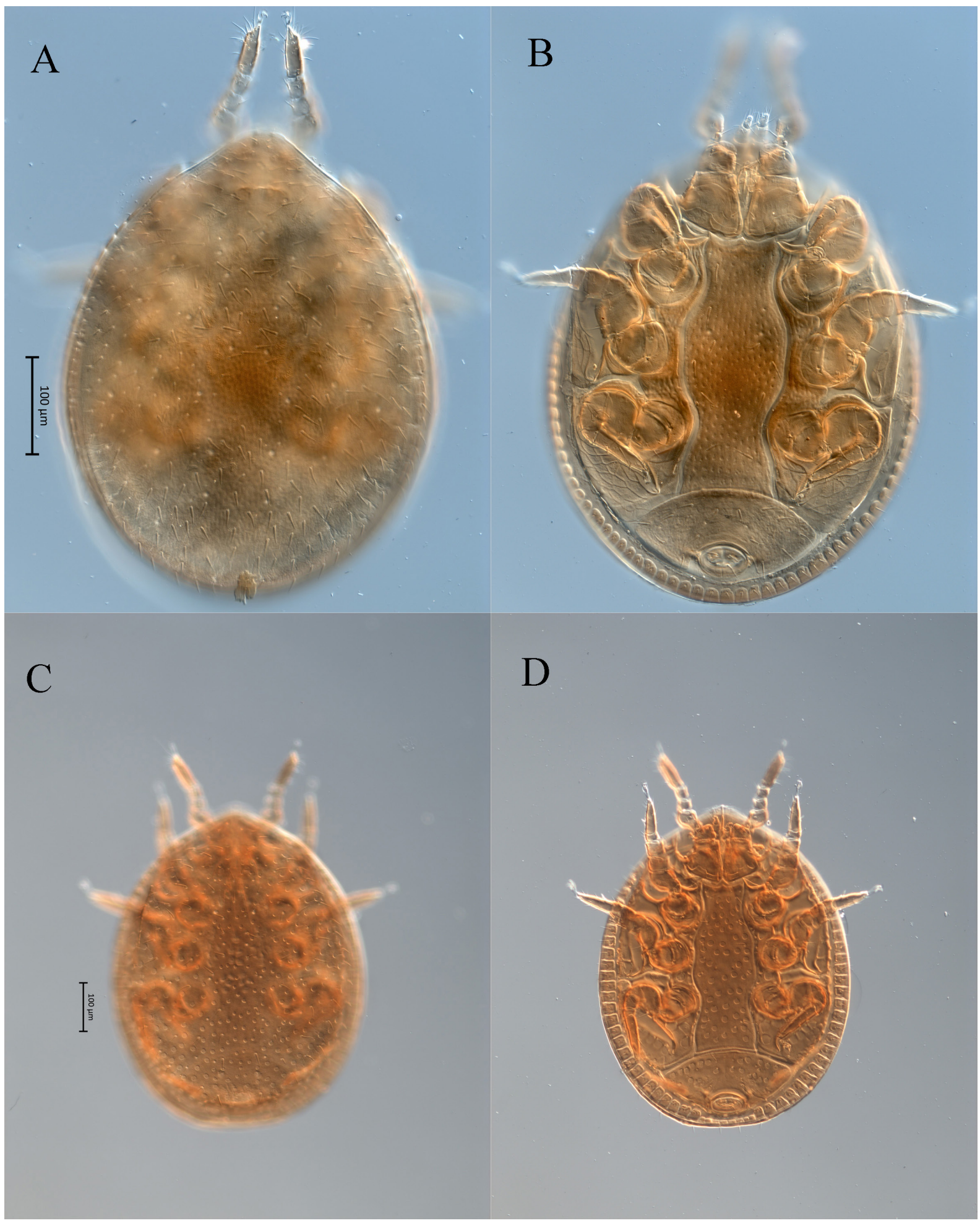

Fig. 3. A, B-Trichouropoda polytricha, deutonymph, dorsal and ventral views, respectively, C, D-Trichouropoda karawaiewi, deutonymph, dorsal and ventral views, respectively.

Material examined: 633 deutonymphs, Russia, Tyumen Region, Tyumen District, vicinity of settlement Uspenka, $57^{\circ} 04^{\prime} \mathrm{N}, 65^{\circ} 04^{\prime} \mathrm{E}$, in alcohol sediments containing numerous specimens of European spruce bark beetle Ips typographus collected by pheromone traps, 22 May 2017, coll.
A.A. Khaustov; 415 deutonymphs, same locality, 28 May 2017; 441 deutonymphs, same locality, 5 June 2017; 56 deutonymphs, same locality, 14 June 2017; 161 deutonymphs, same locality, 16 June 2017. 


\section{Trichouropoda karawaiewi (Berlese, 1904)}

(Figs. 3C, D, 38E, F)

This species is known from the Eastern and Central Europe (Berlese 1903 (1904); Mašán 2001). It has been recorded from various nests of birds and ants, as well as under the bark of dead trees (Mašán 2001). Vrabec et al. (2012) reported this species being phoretic on I. typographus in Slovakia.

In our study, deutonymphs of T. karawaiewi were found to be phoretic on Ips typographus. Adults of T. karawaiewi were abundant in the galleries of I. typographus. This is the first record of T. karawaiewi in Russia.

Material examined. Five females, 2 males, Tyumen Region, Tyumen District, vicinity of settlement Uspenka, $57^{\circ} 04^{\prime} \mathrm{N}, 65^{\circ} 04^{\prime} \mathrm{E}, 22$ April-5 May 2016, in the galleries of Ips typographus, coll. A.A. Khaustov; 1 deutonymph, Russia, Tyumen Region, Tyumen District, vicinity of settlement Uspenka, $57^{\circ} 04^{\prime} \mathrm{N}, 65^{\circ} 04^{\prime} \mathrm{E}$, on Ips typographus collected by pheromone traps, 22 May 2017, coll. A.A. Khaustov; 12 deutonymphs, same locality, 28 May 2017; 10 deutonymphs, same locality, 5 June 2017; 5 deutonymphs, same locality, 14 June 2017.

\section{Trichouropoda structura Hirschmann and Zirngiebl-Nicol, 1961}

(Figs. 4A, B)

This species has been recorded in Germany, Poland, Slovakia, and Russia (Siberia) (Mašán 2001). Deutonymphs of this species have been reported to be phoretic on Thanasimus sp. (Cleridae). This species was also found in the galleries of Pityogenes chalcographus (Curculionidae: Scolytinae) (Kiełczewski and Wiśniewski 1983).

In our study, T. structura was a rare species (Table 1). Apparently, it is not associated with I. typographus and probably got into our pheromone traps accidentally, with other beetles.

Material examined. Two deutonymphs, Russia, Tyumen Region, Tyumen District, vicinity of settlement Uspenka, $57^{\circ} 04^{\prime} \mathrm{N}, 65^{\circ} 04^{\prime} \mathrm{E}$, in alcohol sediments containing numerous specimens of European spruce bark beetle Ips typographus collected by pheromone traps, 28 May 2017, coll. A.A. Khaustov.

\section{Infraorder Gamasina \\ Family Parasitidae}

\section{Schizosthetus sp.}

(Figs. 4C, D)

Three species of the genus Schizosthetus AthiasHenriot, 1982 have been described: Sch. lyriformis
(McGraw and Farrier 1969) from North and Central Americas; Sch. vicarius Athias-Henriot, 1982 from North America; and Sch. simulatrix Athias-Henriot, 1982 from the Canary Islands and Portugal (AthiasHenriot 1982). In North and Central America, Sch. lyriformis is associated with Ips avulsus, I. calligraphus, I. confusus, I. grandicollis, Dendroctonus brevicomis, $D$. frontalis, $D$. simplex, $D$. valens, Onthotomicus latidens. Sch. lyriformis preys on the eggs and larvae of bark beetles (Hofstetter et al. 2009). Al-Atawi et al. (2002) redescribed this species based on all instars. Kalúz et al. (2003) redescribed Sch. simulatrix based on material from Slovakia, Germany, Sweden, and France. These authors re-examined specimens of Vulgarogamasus sp., which were previously reported as associates of bark beetles Ips sexdentatus in France (Lieutier 1978) and of Ips typographus in Germany (Moser and Bogenschütz 1984) and Sweden (Moser et al. 1989). Kalúz et al. (2003) identified them as Sch. simulatrix. The authors also suggested that specimens identified as Parasitus (Vulgarogamasus) lyriformis in northern Russia (Arkhangelsk) (Tichomirov 1977) and South Siberia (Altai Republic) (Davydova and Nikolskii 1986) also belonged to Sch. simulatrix. Plumari (2008) recorded nymphs and adults of Sch. simulatrix in Italy in the galleries of bark beetles Crypturgus cribellus, Crypturgus mediterraneus, Xyleborinus saxesenii, and weevils Brachytemnus porcatus and Dryophthorus corticalis. This mite species has also been recorded in Croatia on Pityocteines curvidens (Pernek et al. 2008, 2012) and in Latvia on Hylurgops palliatus (Salmane and Telnov 2009). Sch. vicarius AthiasHenriot, 1982 is known only from the type series discovered in the moss and soil on the trunk of a Pseudotsuga menziesii. We have previously reported deutonymphs of Schizosthetus sp. on Pityogenes chalcographus in Western Siberia (Khaustov et al. 2016).

In our study, we have documented the phoresy of Schizosthetus sp.'s deutonymphs on Ips typographus. Only two species of the genus Schizosthetus are known from deutonymphs (Sch. lyriformis and Sch. simulatrix), so the correct determination could only be possible after studying adult mites. Deutonymphs of Schizosthetus have no preference for a specific attachment site on the bark beetle host; during phoresy, they move freely across a beetle's body.

Material examined. Three deutonymphs, Russia, Tyumen Region, Tyumen District, vicinity of settlement Uspenka, $57^{\circ} 04^{\prime} \mathrm{N}, 65^{\circ} 04^{\prime} \mathrm{E}$, in 


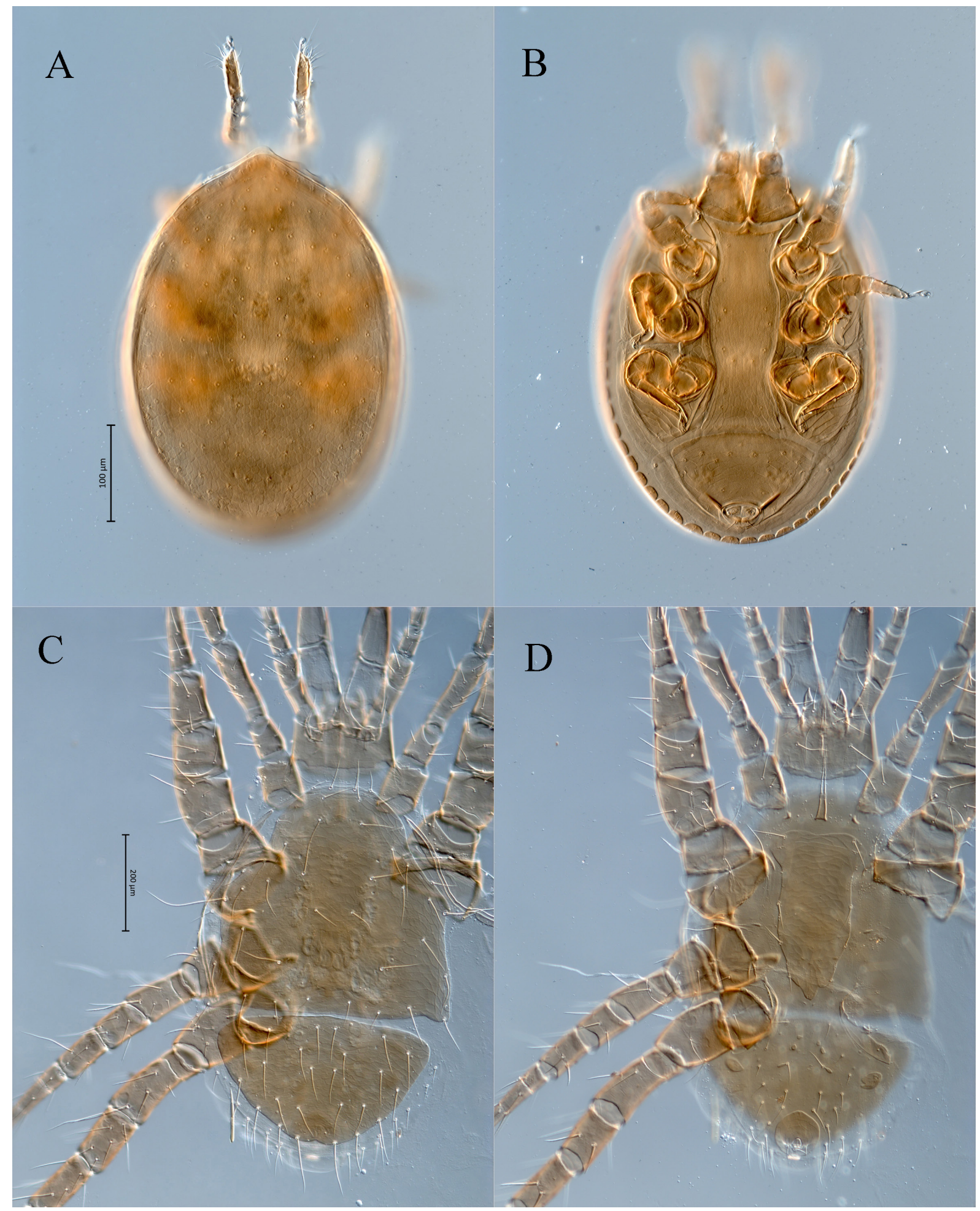

Fig. 4. A, B-Trichouropoda structura, deutonymph, dorsal and ventral views, respectively, C, D—Schizosthetus sp., deutonymph, dorsal and ventral views, respectively.

alcohol sediments containing numerous specimens of European spruce bark beetle Ips typographus collected by pheromone traps, 22 May 2017, coll. A.A. Khaustov; 8 deutonymphs, same locality, 28 May 2017; 1 deutonymph, same locality, 5 June 2017.

\section{Family Digamasellidae}

\section{Dendrolaelaps (Ipidodendrolaelaps) quadrisetus (Berlese, 1920)}

(Figs. 5A, B, 41A-C, 43A)

Deutonymphs of Dendrolaelaps quadrisetus were described based on specimens obtained from 


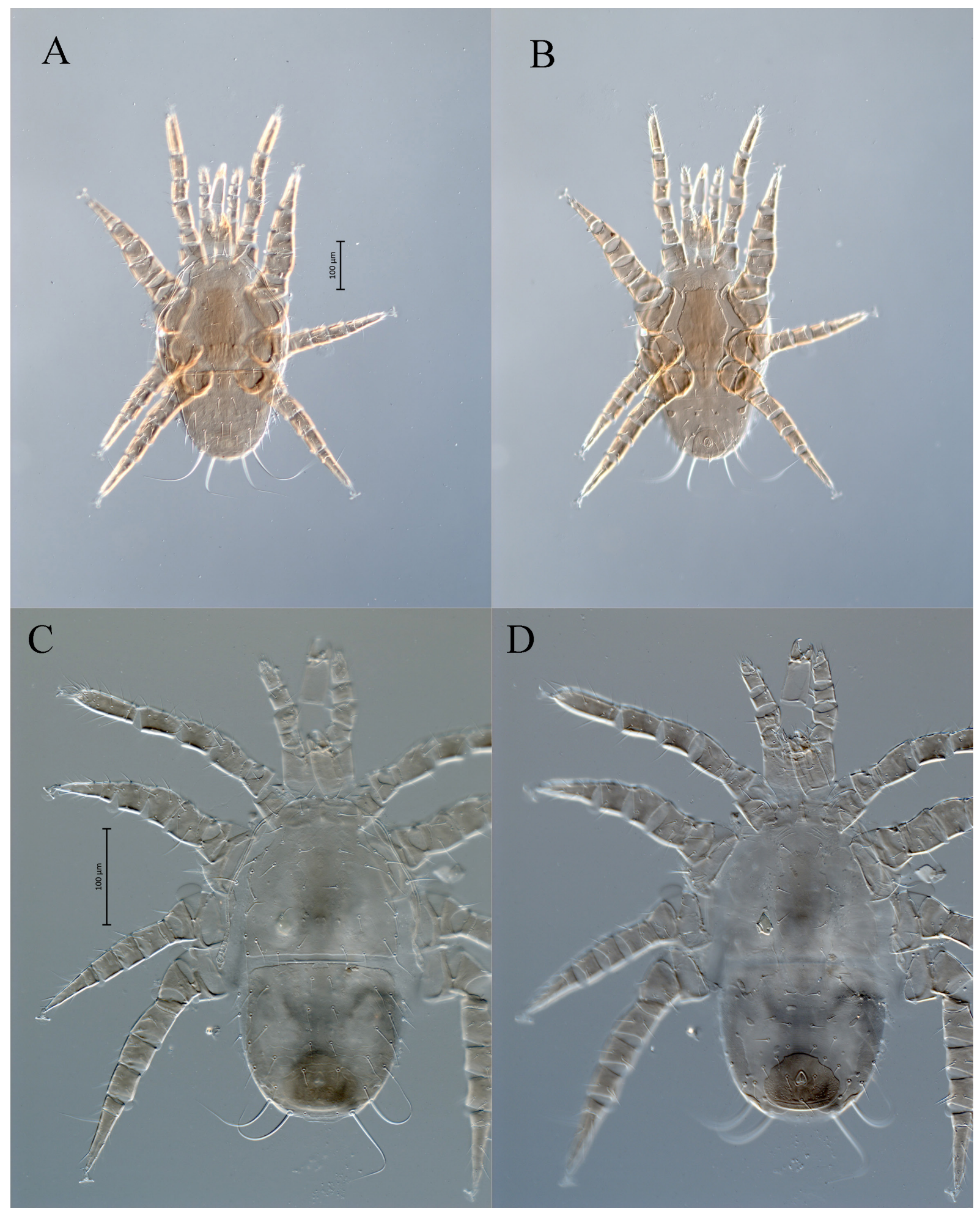

Fig. 5. A, B-Dendrolaelaps quadrisetus, deutonymph, dorsal and ventral views, respectively, C, D—Dendrolaelaps pini, deutonymph, dorsal and ventral views, respectively.

the bark of a coniferous tree lying on the ground (Berlese 1920 (1921)). This species has been recorded in the Palaearctic (widely distributed in Europe, known in Algeria, Asian Russia, and Japan), the Nearctic (USA, Canada, Mexico) and the Neotropics (Guatemala) (Chaires-Grijalva et al.
2013; Hirschmann and Wiśniewski 1982; Knee et al. 2013; Shcherbak 1980). Mites were found in association with Dendroctonus frontalis, D. pseudotsugae, D. valens, Gnathotrichus materarius, Ips avulsus, I. calligraphus, I. confusus, I. emarginatus, I. grandicollis, I. pini, I. ponderosa, Orthotomicus 
latidens, Pachylobius picivorus in the USA (Hunter and Davis 1963; Hurlbutt 1967; Knee et al. 2013; Moser and Roton 1971; Pfammatter et al. 2016); Ips typographus in Germany (Moser and Bogenschütz 1984); Ips typographus japonicus in Japan (Moser et al. 1997); Crypturgus cinereus, Dryocoetes autographus, Hylastes opacus, Hylestinus varius, Hylurgops glabratus, H. palliatus, Ips acuminatus, I. amitinus, I. cembrae, I. typographus, Pityogenes chalcographus, Pityokteines curvidens, P. vorontzowi, Polygraphus poligraphus, Scolytus intricatus, $S$. ratzeburgii, Tomicus minor, T. piniperda, Xyleborus cryptographus in Poland (Gwiazdowicz 2008); P. curvidens, P. spinidens, P. vorontzowi, I. cembrae, I. typographus in Croatia (Pernek et al. 2008, 2012; Wirth et al. 2016); I. typographus in Bulgaria (Takov et al. 2009); I. typographus in Slovakia (Vrabec et al. 2012); Ips sexdentatus in Slovenia (Moraza et al. 2013); I. typographus in Finland (Penttinen et al. 2013); I. typographus in the Czech Republic (Čejka and Holuša 2014); I. typographus in Romania (Poliță et al. 2016). In Russia, this species is known from the Arkhangelsk Region and Primorsky Krai (Shcherbak 1980). The biology of D. quadrisetus was studied in detail by Kinn (1967), who has noted that in view of its predaceous habits, this mite may have an important role in controlling bark beetle populations. We have observed $D$. quadrisetus deutonymphs feeding on the eggs of Ips typographus. During this process, the mite deutonymphs have significantly increased in size (Fig. 43A). Deutonymphs of D. quadrisetus are usually phoretic on the elytral declivities (Figs. $41 \mathrm{~A}, \mathrm{~B})$ or under the elytra of bark beetles.

This is the first record of D. quadrisetus in Western Siberia and on the Kuril Islands.

Material examined. One deutonymph, Russia, Tyumen Region, Tyumen District, vicinity of settlement Uspenka, $57^{\circ} 04^{\prime} \mathrm{N}, 65^{\circ} 04^{\prime} \mathrm{E}, 5$ May 2017 , on Ips typographus collected under the bark of Siberian spruce (Picea obovata), coll. A.A. Khaustov; 1 deutonymph, same locality, 26 July 2016, in alcohol sediments containing numerous specimens of I. typographus collected by pheromone traps, coll. A.A. Khaustov; 4 females, 1 male, same locality, 27 July 2016, in galleries of I. typographus under the bark of Siberian spruce, coll. A.A. Khaustov; 5 deutonymphs, Russia, Primorsky Krai, Lazo, $43^{\circ} 30^{\prime} 04.6^{\prime \prime} \mathrm{N}, 133^{\circ} 34^{\prime} 47.1^{\prime \prime} \mathrm{E}, 28$ August 2016, in the galleries of Ips typographus under the bark of Korean spruce Picea koraiensis, coll. A.A. Khaustov; 1,990 deutonymphs, Russia, Tyumen Region,
Tyumen District, vicinity of settlement Uspenka, $57^{\circ} 04^{\prime} \mathrm{N}, 65^{\circ} 04^{\prime} \mathrm{E}$, in alcohol sediments containing numerous specimens of Ips typographus collected by pheromone traps, 22 May 2017, coll. A.A. Khaustov; 628 deutonymphs, same locality, 28 May 2017; 1,274 deutonymphs, same locality, 5 June 2017; 295 deutonymphs, same locality, 14 June 2017; 126 deutonymphs, same locality, 16 June 2017; 5 deutonymphs, Russia, Kunashir Island, on Ips typographus japonicus, 5 August 2017, coll. A.A. Khaustov.

\section{Dendrolaelaps (Insectolaelaps) pini Hirschmann, 1960}

(Figs. 5C, D)

Dendrolaelaps pini was described based on specimens obtained from bark beetles Hylurgus ligniperda and Hylastes sp. discovered on pine trees in Germany (Hirschmann 1960). Skorupski and Gwiazdowicz (1996) recorded this species on specimens recovered through alcohol washing of the contents of Ips typographus pheromone traps in Poland. Salmane (2005) reported this species in Latvia on multiple species of polypore fungi. The record of $D$. pini from the former USSR by Shcherbak (1980) refers to another species, D. latopini Hirschmann and Wisniewski, 1982 (Hirschmann and Wiśniewski 1982).

$D$. pini is new for the fauna of Russia.

Material examined. Three deutonymphs, Russia, Tyumen Region, Tyumen District, vicinity of settlement Uspenka, $57^{\circ} 04^{\prime} \mathrm{N}, 65^{\circ} 04^{\prime} \mathrm{E}$, in alcohol sediments containing numerous specimens of European spruce bark beetle Ips typographus collected by pheromone traps, 22 May 2017, coll. A.A. Khaustov.

\section{Dendrolaelaps (Apophyseodendrolaelaps) disetosimilis Hirschmann, 1960}

(Figs. 6A, B)

This species was described from Germany as an associate of Dryocoetes autographus (Hirschmann 1960). Shcherbak (1980) reported this species in Russia (Novosibirsk Region, Kamchatka Region) and Ukraine. Dendrolaelaps disetosimilis has been recovered from the nest of a European sand martin (Riparia riparia) in Ukraine (Shcherbak and Balan 1982); under the bark of the Scots pine (Pinus sylvestris) infested by $\mathrm{Hy}$ lurgops palliatus in Latvia (Salmane 2006). This species was recorded in association with bark beetles: Cryphalus piceae, Dryocoetes autogra- 


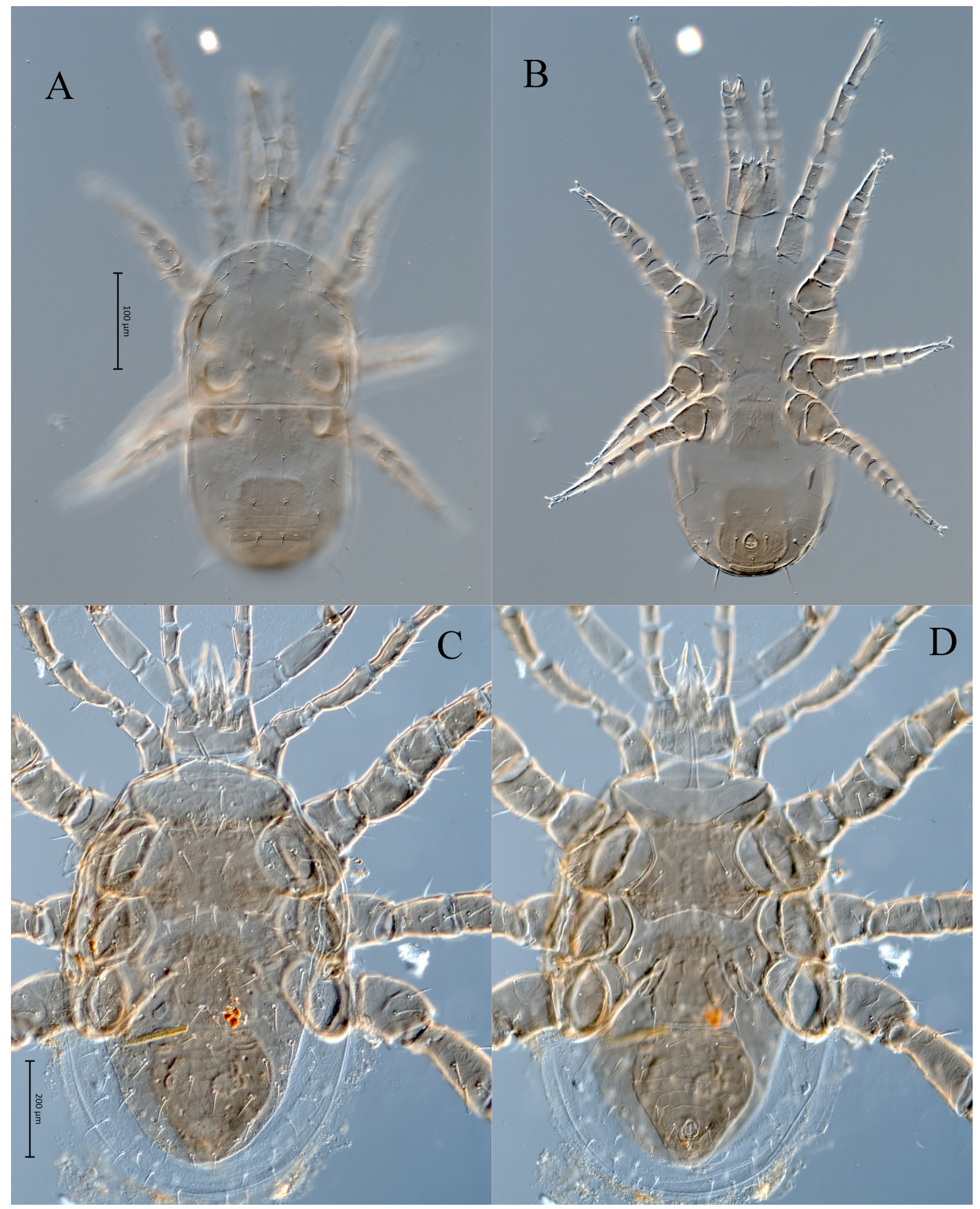

Fig. 6. A, B-Dendrolaelaps disetosimilis, female, dorsal and ventral views, respectively, C, D-Macrocheles ivanovi, female, dorsal and ventral views, respectively.

phus, Hylurgops glabratus, H. palliatus, H. ligniperda, Ips amitinus, I. cembrae, I. typographus, Orthotomicus laricis, Pityogenes chalcographus, Pityokteines curvidens, $P$. spinidens, $P$. vorontzovi, Polygraphus poligraphus, Tomicus piniperda in Poland (Gwiazdowicz 2008). It was also recorded in the soil of Central Yakutia (Russia) (Alekseev et al. 2011).

Material examined. Two females, one male, Russia, Sakhalin Island, in the galleries of I. typographus under the bark of Sakhalin spruce Picea glehnii, $46^{\circ} 47^{\prime} 04.9^{\prime \prime} \mathrm{N}, 142^{\circ} 23^{\prime} 13.0^{\prime \prime} \mathrm{E}$, coll. A.A. Khaustov. 
Family Macrochelidae

\section{Macrocheles (s. str.) ivanovi Bregetova and Koroleva, 1960}

\author{
(Figs. 6C, D, 41D-F)
}

This species was described based on samples obtained from a rotten spruce tree in western Russia (Leningrad Region), as well as from a striped field mouse (Apodemus agrarius) in eastern Russia (Primorsky Krai) (Bregetova and Koroleva 1960). These mites also occur in the galleries of Dryocoetes sp. in pine branches in Germany (Bregetova 1977b; Hirschmann 1970).

Previously, Macrocheles ivanovi had never been reported as an associate of Ips typographus. We did not observe phoresy of this species on $I$. typographus.

Material examined. One female, 2 deutonymphs, Russia, Primorsky Krai, Lazo, 43 $3^{\circ} 30^{\prime} 04.6^{\prime \prime} \mathrm{N}$, $133^{\circ} 34^{\prime} 47.1^{\prime \prime} \mathrm{E}, 28$ August 2016, in the galleries of Ips typographus under the bark of Korean spruce Picea koraiensis, coll. A.A. Khaustov; 2 females, Tomsk Region, vicinity of Tomsk, in the galleries of Ips typographus under the bark of Siberian spruce Picea obovata, 16 September 2017, 56 $18^{\prime} 56.7^{\prime \prime}$ N, $085^{\circ} 10^{\prime} 36.9^{\prime \prime} \mathrm{E}$, coll. A.A. Khaustov.

\section{Family Ascidae \\ Gamasellodes tatricus Gwiazdowicz and Walter, 2005}

(Figs. 7A, B)

Gamasellodes tatricus was described based on specimens obtained from forest litter in the Tatra National Park in Poland (Gwiazdowicz and Walter 2005). It has never been recollected since. Other species of the genus Gamasellodes have been recovered from soil, litter, humus, sod, debris, plants, ant nests, and bark beetle galleries. Gamasellodes rectiventris Lindquist, 1971 was described based on specimens recovered from Dendroctonus frontalis' boring dust, which was discovered under the bark of a Loblolly pine (Pinus taeda). G. rectiventris specimens were also obtained from the inner bark of $P$. taeda, from which $D$. frontalis emerged. Finally, $G$. rectiventris specimens were obtained from under the bark of P. taeda, from which Ips avulvus and I. calligraphus emerged (De Moraes et al. 2016; Lindquist 1971). Gamasellodes bicolor (Berlese, 1918) and G. insignis (Hirschmann, 1962) were also found in the galleries of bark beetles (Gwiazdowicz 2007; Hurlbutt 1971; Kiełczewski and Wiśniewski 1983; Walter 1987).
Previously, Gamasellodes has never been reported as a phoretic mite. This is the first record of G. tatricus in Russia.

Material examined. One female, Russia, Tyumen Region, Tyumen District, vicinity of settlement Uspenka, $57^{\circ} 04^{\prime} \mathrm{N}, 65^{\circ} 04^{\prime} \mathrm{E}, 28$ May 2017 , in alcohol sediments containing numerous specimens of Ips typographus collected by pheromone traps, coll. A.A. Khaustov.

\section{Family Melicharidae}

\section{Proctolaelaps fiseri Samšiňák, 1960}

(Figs. 7C, D)

This species was identified in Slovakia, in association with Ips typographus (Samšiňák 1960). This predatory species is widely distributed in the Holarctic, where it is associated with various subcortical beetles, especially bark beetles (Hofstetter et al. 2015). Westerboer (1963) recorded P. fiseri in Germany as an associate of several species of bark beetles (I. typographus, Hylurgops palliatus, Dryocoetes autographus, Tomicus piniperda, Pityokteines curvidens, Ernoporicus fagi), as well as of a cerambycid beetle Spondylis buprestoides. In the USA, Lindquist and Hunter (1965) reported P. fiseri in the galleries of Ips calligraphus; Moser (1975) — in the galleries of Dendroctonus frontalis; Knee et al. (2013) - in the galleries of Hylastes porculus. P. fiseri has also been recorded in Latvia on a dead pine that was inhabited by Hylurgops palliatus (Salmane 2007). P. fiseri was also recovered in the galleries of I. typographus in Finland (Penttinen et al. 2013). Gwiazdowicz (2008) also identified this mite in Poland as an associate of 38 species of bark beetles. Furthermore, it has been recorded in European Russia in the galleries of I. typographus (Maslov and Matusevich 2008) and in Western Siberia (Davydova and Nikolskii 1986). We have previously reported this species in association with Polygraphus proximus, P. subopacus, Ips typographus, I. typographus japonicus, Hylurgops glabratus, Ips acuminatus, and Tetropium sp. (Cerambycidae) in Asian Russia (Trach and Khaustov 2017b). Our erroneous identification of $P$. fiser $i$ on Pityogenes chalcographus in Western Siberia is corrected here to Proctolaelaps hystricoides Lindquist and Hunter, 1965 (Khaustov et al. 2016; Trach and Khaustov 2017b) (see below).

Females of $P$. fiseri have no specific attachment sites for phoresy on bark beetles; they freely move across a beetle's body during phoresy. 

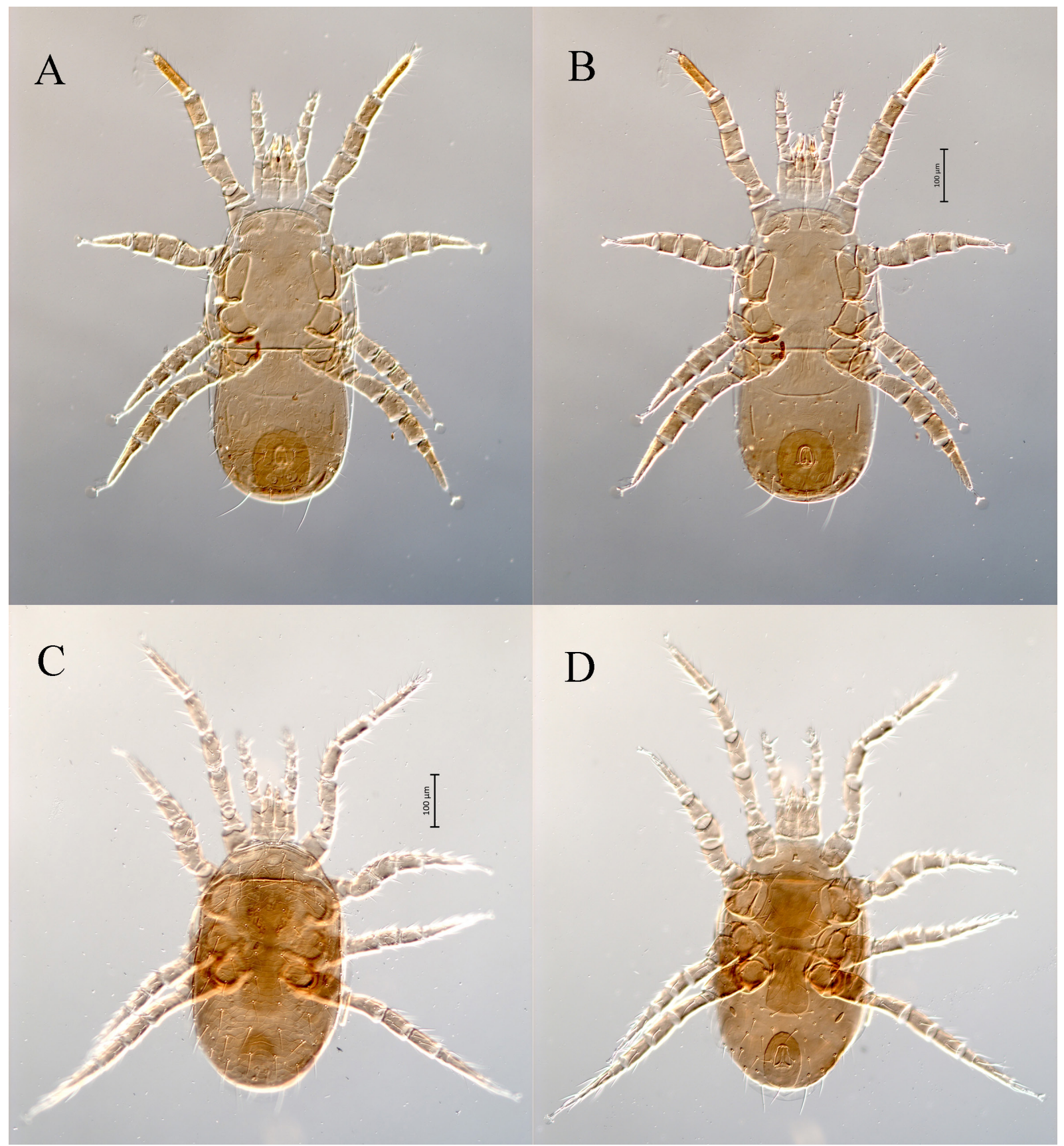

Fig. 7. A, B-Gamasellodes tatricus, female, dorsal and ventral views, respectively, C, D_Proctolaelaps fiseri, female, dorsal and ventral views, respectively.

Material examined. One female, Russia, Tyumen Region, Tyumen District, vicinity of settlement Uspenka, $57^{\circ} 04^{\prime} \mathrm{N}, 65^{\circ} 04^{\prime} \mathrm{E}$, 14 July 2016 , in galleries of Ips typographus under the bark of Siberian spruce (Picea obovata), coll. A.A. Khaustov; 5 females, same locality, in alcohol sediments containing numerous specimens of Ips typographus collected by pheromone traps, 5 June 2017; 4 females, Russia, Sakhalin Region, Sakhalin Island, on Ips typographus and in its galleries under the bark of Sakhalin spruce (Picea glehnii), $46^{\circ} 47^{\prime} 04.9^{\prime \prime} \mathrm{N}, 142^{\circ} 23^{\prime} 13.0^{\prime \prime} \mathrm{E}, 13$ August 2017, coll. A.A. Khaustov.

\section{Proctolaelaps hystricoides Lindquist and Hunter, 1965}

(Figs. 8A, B)

The type series of $P$. hystricoides originated from the galleries of Orthotomicus caelatus, Dendroctonus monticolae, Trypodendron rufitarsis and Ips calligraphus under the bark of different species of pine trees in Canada and the USA (Lindquist and Hunter 1965). This species has also been recorded in the galleries of Dendroctonus frontalis in the USA (Moser 1975; Moser and Roton 1971). 


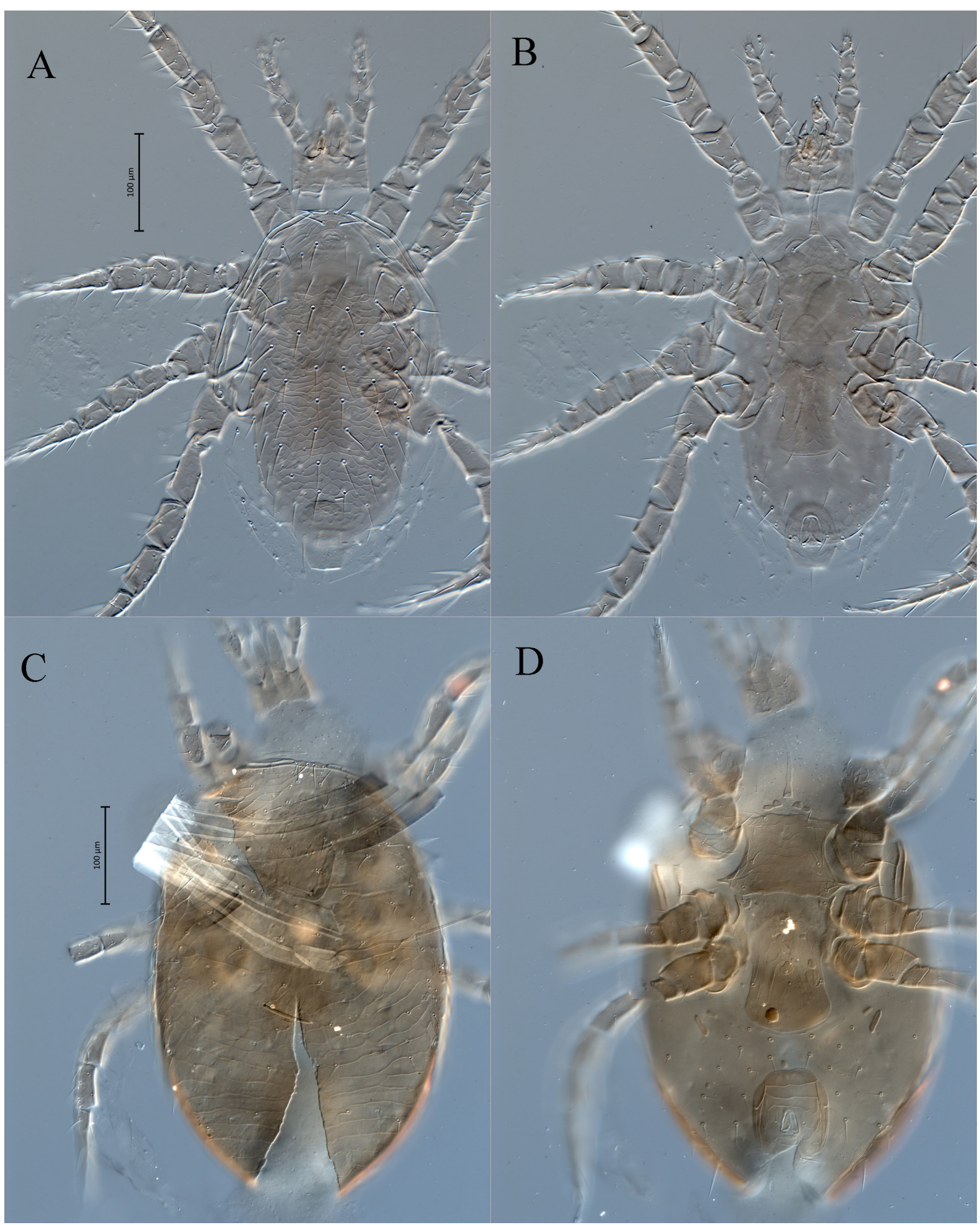

Fig. 8. A, B-Proctolaelaps hystricoides, female, dorsal and ventral views, respectively, C, D_Proctolaelaps juradeus, female, dorsal and ventral views, respectively.

Later, this species was recorded in soil from Iran (Kazemi and Rajaei 2013). Haddad Irani Nejad et al. (2001) reported this species in cotton fields in Iran. These mites also occur on bark beetles Pityokteines spp. that inhabit Silver fir (Abies alba) in Croatia (Pernek et al. 2008). We previously re- ported this species associated with Pityogenes chalcographus, Polygraphus proximus, Hylurgops glabratus, Ips subelongatus and I. typographus in Asian Russia (Trach and Khaustov 2017b).

Material examined. One female, Russia, Tyumen Region, Tyumen District, vicinity of settle- 
ment Uspenka, $57^{\circ} 04^{\prime} \mathrm{N}, 65^{\circ} 04^{\prime} \mathrm{E}$, 5 July 2017 , in alcohol sediments containing numerous specimens of Ips typographus collected by pheromone traps, coll. A.A. Khaustov.

\section{Proctolaelaps jueradeus (Schweizer, 1949)}

$$
\text { (Figs. 8C, D) }
$$

This species is widely distributed in the Holarctic (including Russia) in association with soil and related substrates (Bregetova 1977a; Chant 1963; Evans 1958; Gwiazdowicz 2007; Karg 1993; Makarova 2012; Marchenko 2002, 2012; Salmane 2001; Schweizer 1949; Westerboer 1963). Once it has been recorded in the galleries of an unknown bark beetle species in Poland (Gwiazdowicz 2007). We collected $P$. jueradeus in the sediments produced in the process of alcohol washing of Ips typographus (Trach and Khaustov 2017b).

Phoresy of $P$. jueradeus has never been reported previously.

Material examined. One female, Russia, Tyumen Region, Tyumen District, vicinity of settlement Uspenka, $57^{\circ} 04^{\prime} \mathrm{N}, 65^{\circ} 04^{\prime} \mathrm{E}, 22$ May 2017 , in alcohol sediments containing numerous specimens of Ips typographus collected by pheromone traps, coll. A.A. Khaustov.

\section{Order Trombidiformes \\ Suborder Prostigmata \\ Family Ereynetidae}

\section{Ereynetes (Huntereynetes) sp.}

(Figs. 9A, B)

This species has been reported as Ereynetes scutulis Hunter, 1964, E. near scutulis and E. propescutulis Hunter and Rosario, 1989 in several localities in Europe in associations with various bark beetles (Moser et al. 1989; Penttinen et al. 2013; Pernek et al. 2008). Our specimens differ from $E$. scutulis by distinctly longer (but shorter than those in E. propescutulis) dorsal idiosomal setae, and they may represent an undescribed species. This species is abundant in the galleries of Ips typographus; however, it is very difficult to collect because it is one of the fastest mites.

This species has no specific attachment sites on hosts; it actively moves around the beetle's body during phoresy.

Material examined. One female, Russia, Tyumen Region, Tyumen District, vicinity of settlement Uspenka, $57^{\circ} 04^{\prime} \mathrm{N}, 65^{\circ} 04^{\prime} \mathrm{E}$, in alcohol sediments containing numerous specimens of European spruce bark beetle Ips typographus collected by pheromone traps, 22 May 2017, coll. A.A. Khaustov; 3 females, same locality, 28 May 2017; 7 females, same locality, 5 June 2017; 2 females, same locality, 16 June 2017.

\section{Family Cheyletidae}

\section{Mexecheles virginiensis (Baker, 1949)}

$$
\text { (Figs. 9C, D) }
$$

This species was described in the USA (Virginia) (Baker 1949). Later, it has been recorded in various other localities in North America: USA (Alabama, Louisiana, Mississippi, Nevada, and Utah), Canada and Honduras (Smiley and Moser 1970; Summers and Price 1970). In the Old World, it has been recently recorded in Finland as an associate of Ips typographus (Penttinen et al. 2013) and in European Russia (Bochkov and Abramov 2016). This is a new record of this species in the Asian part of Russia.

The attachment site of this species on beetles is unknown. We collected females of M. virginiensis only in the alcohol sediments and in galleries.

Material examined. One female, Russia, Tyumen Region, Tyumen District, vicinity of settlement Uspenka, $57^{\circ} 04^{\prime} \mathrm{N}, 65^{\circ} 04^{\prime} \mathrm{E}$, in alcohol sediments containing numerous specimens of European spruce bark beetle Ips typographus collected by pheromone traps, 5 June 2017, coll. A.A. Khaustov; 1 female, same locality, in the galleries of I. typographus, 5 July 2016; 1 male, same locality, in the galleries of I. typographus, 3 August 2016.

\section{Family Dolichocybidae}

\section{Dolichocybe sibiriensis Khaustov, 2017}

$$
\text { (Figs. 10A, B) }
$$

This species was described in Western Siberia, where it was recovered from alcohol washing of the contents of Ips typographus pheromone traps (Khaustov 2017c).

The attachment site of this species on beetles is unknown. We collected females of $D$. sibiriensis only in alcohol sediments.

Material examined. Three females, Russia, Tyumen Region, Tyumen District, vicinity of settlement Uspenka, $57^{\circ} 04^{\prime} \mathrm{N}, 65^{\circ} 04^{\prime} \mathrm{E}$, in alcohol sediments containing numerous specimens of European spruce bark beetle Ips typographus collected by pheromone traps, 22 May 2017, coll. A.A. Khaustov. 


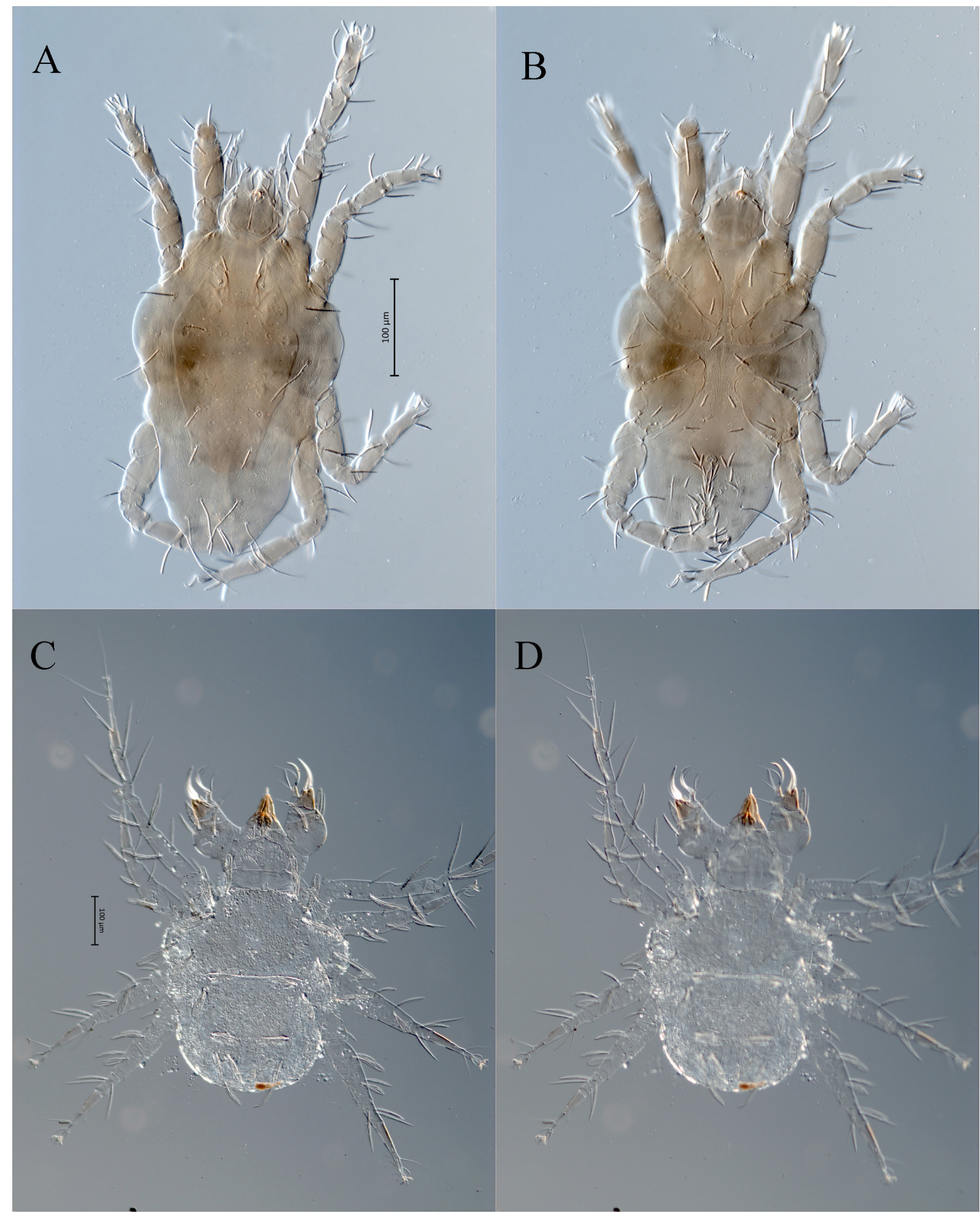

Fig. 9. A, B-Ereynetes sp., female, dorsal and ventral views, respectively, C, D-Mexecheles virginiensis, female, dorsal and ventral views, respectively.

\section{Family Pyemotidae}

\section{Pyemotes sp.}

(Figs. 10C, D)

Only one female of an undetermined species belonging to the ventricosus species-group was collected. In this species group, identification of species is only possible using males (Cross et al. 1981). Mites of the ventricosus group attack a wide range of prey, e.g., small larvae of Lepidoptera, Hymenoptera and Coleoptera, including juvenile stages of bark beetles (Khaustov 1998). Mites of 


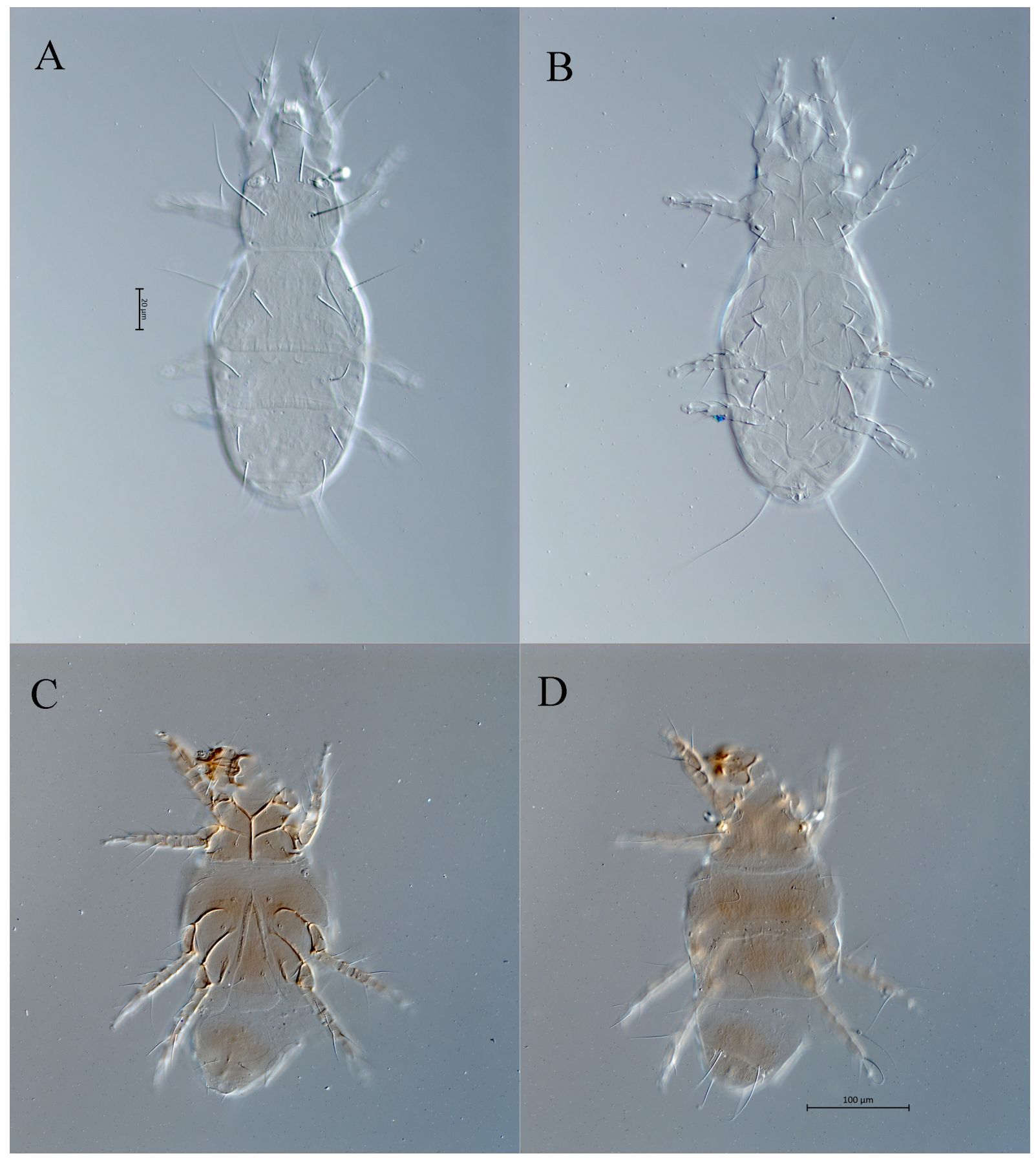

Fig. 10. A, B-Dolichocybe sibiriensis, female, dorsal and ventral views, respectively, C, D—Pyemotes sp., female, dorsal and ventral views, respectively.

the ventricosus species-group could be dispersed by wind.

Material examined. One female, Russia, Tyumen Region, Tyumen District, vicinity of settlement Uspenka, $57^{\circ} 04^{\prime} \mathrm{N}, 65^{\circ} 04^{\prime} \mathrm{E}$, in alcohol sediments containing numerous specimens of European spruce bark beetle Ips typographus collected by pheromone traps, 5 June 2017, coll. A.A. Khaustov.

\section{Family Acarophenacidae}

\section{Aethiophenax ipidarius (Redikortzev, 1947)}

(Figs. 11A, B, 36A-D, 43B)

This species was described in central Russia, where it was recovered from Ips typographus (Redikortzev 1947). It has also been recorded in Finland, Poland, Germany and Sweden as an associate of Ips typographus (Kiełczewski and Wiśniewski 1983; Moser and Bogenschütz 1984; 


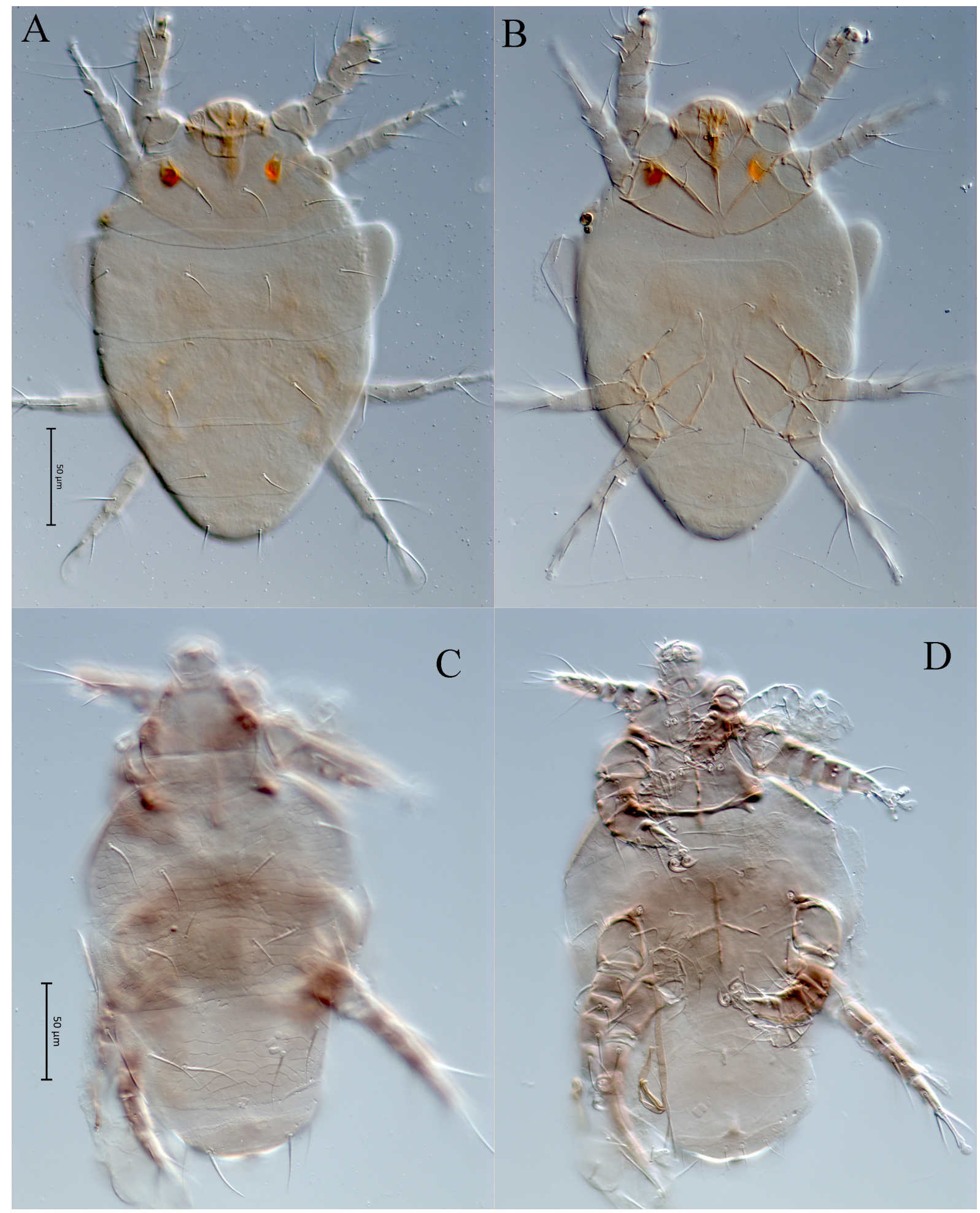

Fig. 11. A, B-Aethiophenax ipidarius, female, dorsal and ventral views, respectively, C, D_Microdispodides moseri, female, dorsal and ventral views, respectively.

Moser et al. 1989; Penttinen et al. 2013). Cross and Moser (1971) reported this species in North America (Ontario and California). Khaustov (1999) redescribed this species based on specimens collected in northwestern Russia from bark beetles Ips typographus, I. amitinus, and Ortho- tomicus laricis. It has recently been recorded in Western Siberia in association with Ips typographus and I. sexdentatus (Khaustov et al. 2017). The biology of Ae. ipidarius is unknown, but all members of the family Acarophenacidae are egg parasitoids of various insects (Kaliszewski et al. 
1995), and this species is probably a parasitoid of bark beetle eggs.

Females of this mite usually attach to the area between the coxae of I. typographus (Figs. 36A-D, 9B). One or two females are phoretic on one beetle, but in some cases, up to 15 females can be found on one beetle (Fig. 43B).

Material examined. Ten females, Russia, Tyumen Region, Tyumen District, vicinity of settlement Uspenka, $57^{\circ} 04^{\prime} \mathrm{N}, 65^{\circ} 04^{\prime} \mathrm{E}$, in alcohol sediments containing numerous specimens of European spruce bark beetle Ips typographus collected by pheromone traps, 22 May 2017, coll. A.A. Khaustov; 5 females, same locality, 28 May 2017; 3 females, same locality, 5 June 2017; 3 females, same locality, 14 June 2017; 3 females, Tomsk Region, vicinity of Tomsk, $56^{\circ} 18^{\prime} 56.7^{\prime \prime} \mathrm{N}$, $085^{\circ} 10^{\prime} 36.9^{\prime \prime} \mathrm{E}$, on Ips typographus, 31 May 1916, coll. A.A. Khaustov.

\section{Family Pygmephoridae}

\section{Microdispodides moseri Khaustov, 2018}

$$
\text { (Figs. 11C, D) }
$$

This species was described in Western Siberia, where it was recovered through alcohol washing of the contents of Ips typographus traps (Khaustov 2018).

The attachment site of this species on beetles is unknown. We collected females of M. moseri only in the alcohol sediments.

Material examined. Two females, Russia, Tyumen Region, Tyumen District, vicinity of settlement Uspenka, $57^{\circ} 04^{\prime} \mathrm{N}, 65^{\circ} 04^{\prime} \mathrm{E}$, in alcohol sediments containing numerous specimens of Ips typographus collected by pheromone traps, 16 June 2017, coll. A.A. Khaustov.

\section{Elattoma crossi Khaustov, 2000}

(Figs. 12A, B, 35A-C)

This species was described based on specimens collected in European Russia, where they were associated with the Ips duplicatus (Sahlberg) bark beetle (Khaustov 2000b). This species has been recently recorded on Ips typographus, in Western Siberia (Khaustov 2017b).

During phoresy, females of this species attach between the coxae of a beetle (Figs. 35A, B).

Material examined. 35 females, Russia, Tyumen Region, Tyumen District, vicinity of settlement Uspenka, $57^{\circ} 04^{\prime} \mathrm{N}, 65^{\circ} 04^{\prime} \mathrm{E}$, in alcohol sediments containing numerous specimens of European spruce bark beetle Ips typographus col- lected by pheromone traps, 22 May 2017, coll. A.A. Khaustov; 23 females, same locality, 28 May 2017; 5 females, same locality, 5 June 2017.

\section{Family Neopygmephoridae \\ Coleopygmephorus bogenschutzi (Mahunka and Moser, 1982)}

(Figs. 12C, D)

This species was originally described as belonging to the Pseudopygmephorus genus Cross, 1965 in Germany, recovered from Ips typographus (Mahunka and Moser 1982). It was recently redescribed and placed into the genus Coleopygmephorus Khaustov and Mandelshtam, 2016 based on material from Ips typographus in Western Siberia (Khaustov 2017b).

The attachment site of this species on the beetle is unknown. We collected females of $C$. bogenschutzi only in the alcohol sediments.

Material examined. Two females, Russia, Tyumen Region, Tyumen District, vicinity of settlement Uspenka, $57^{\circ} 04^{\prime} \mathrm{N}, 65^{\circ} 04^{\prime} \mathrm{E}$, in alcohol sediments containing numerous specimens of Ips typographus collected by pheromone traps, 22 May 2017, coll. A.A. Khaustov; 1 female, same locality, 5 June 2017.

\section{Coleopygmephorus hylophilus (Cooreman, 1963)}

(Figs. 13A, B)

This species was originally described based on specimens from Belgium, as an associate of bark beetles Hylastes ater and $H$. cunicularius (Cooreman 1963). It had been redescribed based on a specimen phoretic on Hylastes ater in Crimea (Khaustov 2017a). Coleopygmephorus hylophilus has also been recorded in Germany, where this species was phoretic on Ips typographus (Moser and Bogenschütz 1984). Khaustov (2017b) has recently recorded this species in Western Siberia, on I. typographus.

The attachment site of this species on the beetle is unknown. We collected females of C. hylophilus only in the alcohol sediments.

Material examined. Twenty seven females, Russia, Tyumen Region, Tyumen District, vicinity of settlement Uspenka, $57^{\circ} 04^{\prime} \mathrm{N}, 65^{\circ} 04^{\prime} \mathrm{E}$, in alcohol sediments containing numerous specimens of European spruce bark beetle Ips typographus collected by pheromone traps, 22 May 2017, coll. A.A. Khaustov; 5 females, same locality, 28 May 2017; 2 females, same locality, 14 June 2017. 


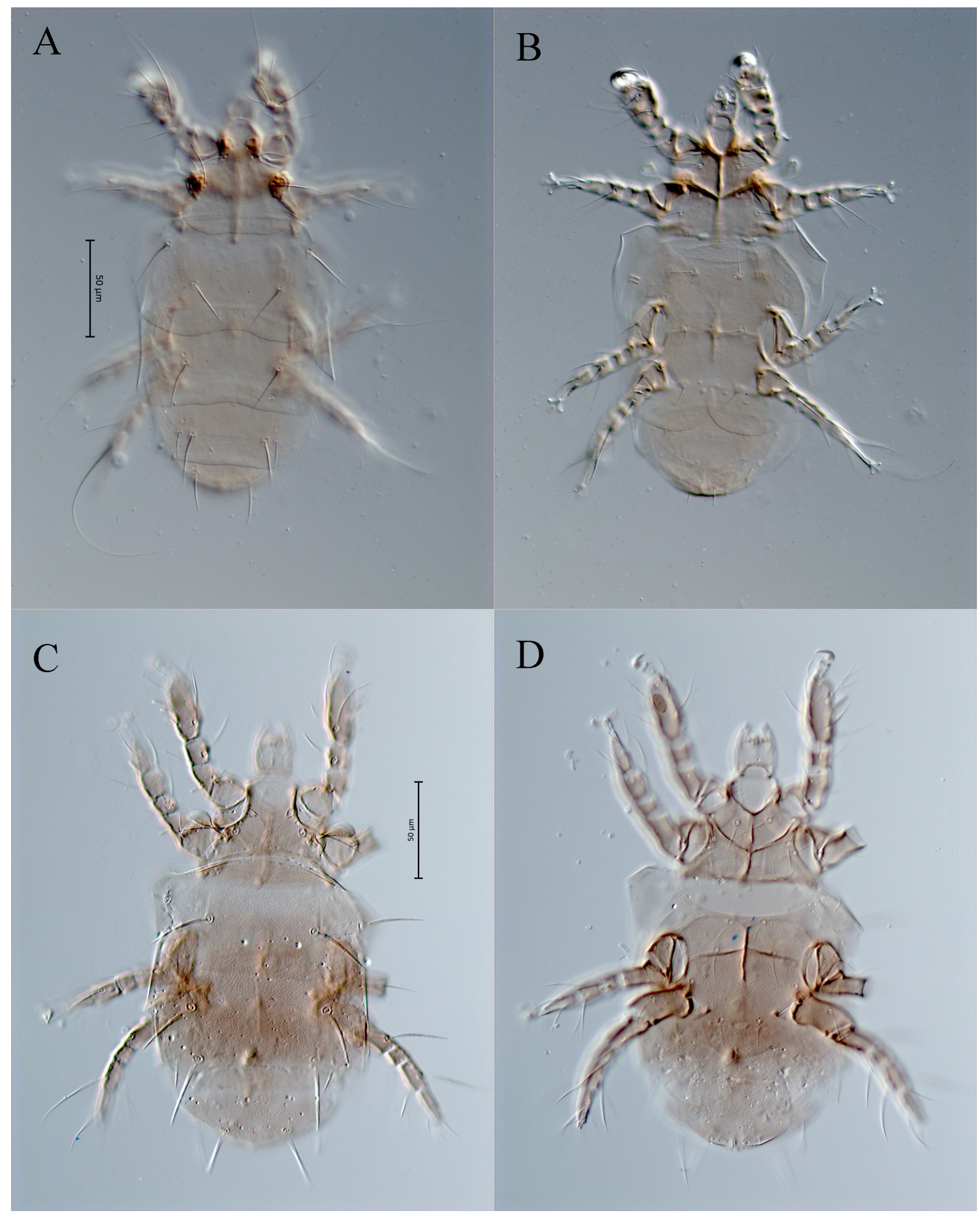

Fig. 12. A, B-Elattoma crossi, female, dorsal and ventral views, respectively, C, D_Coleopygmephorus bogenschutzi, female, dorsal and ventral views, respectively.

\section{Coleopygmephorus typographus Khaustov, 2017}

(Figs. 13C, D)

This species was described based on specimens from Western Siberia (Khaustov 2017a), where it was an associate of bark beetle Ips typographus.

The attachment site of this species on the beetle is unknown. We collected females of $C$. typographus only in the alcohol sediments. 


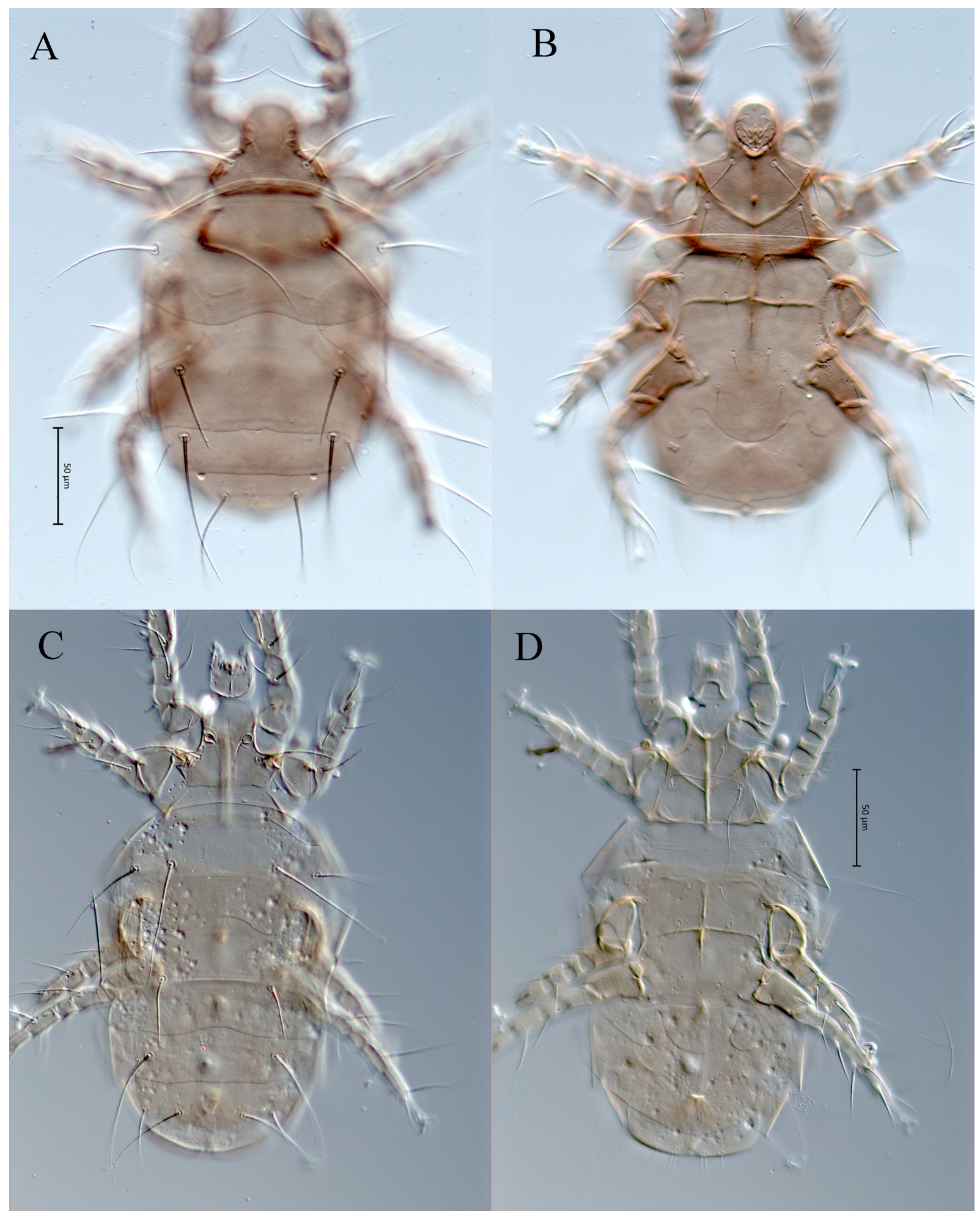

Fig. 13. A, B-Coleopygmephorus hylophilus, female, dorsal and ventral views, respectively, C, D-Coleopygmephorus typographus, female, dorsal and ventral views, respectively.

Material examined. Three females, Russia, Tyumen Region, Tyumen District, vicinity of settlement Uspenka, $57^{\circ} 04^{\prime} \mathrm{N}, 65^{\circ} 04^{\prime} \mathrm{E}$, in alcohol sediments containing numerous specimens of European spruce bark beetle Ips typographus collected by pheromone traps, 24 June 2016, coll. A.A. Khaustov; 1 female, same locality, 16 June 2017. 
A.A. Khaustov, P.B. Klimov, V.A. Trach et al.

\section{Family Scutacaridae \\ Scutacarus pseudoplurisetus Khaustov, 2017}

(Figs. 14A, B)

This species was described based on specimens from Western Siberia (Khaustov 2017b), where it was associated with Ips typographus.

The attachment site of this species on the beetle is unknown. We collected females of S. pseudoplurisetus only in the alcohol sediments.

Material examined. Two females, Russia, Tyumen Region, Tyumen District, vicinity of settlement Uspenka, $57^{\circ} 04^{\prime} \mathrm{N}, 65^{\circ} 04^{\prime} \mathrm{E}$, in alcohol sediments containing numerous specimens of European spruce bark beetle Ips typographus collected by pheromone traps, 22 May 2017, coll. A.A. Khaustov.

\section{Scutacarus scolyti Mahunka and Moser, 1980}

(Figs. 14C, D, 35D-F)

This species was described based on specimens from Germany (Mahunka and Moser 1980), where these mites were phoretic on Ips typographus. It has also been recorded in European Russia, where the mites were recovered from the galleries of Pityogenes chalcographus (Khaustov 2008); and in Western Siberia, where the mites were discovered on I. typographus (Khaustov 2017b).

Phoretic females usually attach between the coxae of the host beetle (Figs. 35D, E).

Material examined. Eight females, Russia, Tyumen Region, Tyumen District, vicinity of settlement Uspenka, $57^{\circ} 04^{\prime} \mathrm{N}, 65^{\circ} 04^{\prime} \mathrm{E}$, in alcohol sediments containing numerous specimens of European spruce bark beetle Ips typographus collected by pheromone traps, 28 May 2017, coll. A.A. Khaustov; 5 females, Russia, Tomsk Region, vicinity of settlement Zavarzino, 56 $26^{\circ} 55.7^{\prime \prime} \mathrm{N}$, $085^{\circ} 06^{\prime} 55.6^{\prime \prime} \mathrm{E}$, on the Ips typographus under the bark of Picea obovata, 28 April 2017, coll. A.A. Khaustov.

\section{Scutacarus muscocicola Sevastianov, 1983}

(Figs. 15A, B)

This species was described based on specimens that came from mosses in Eastern Siberia (Sevastianov 1983). It has also been recorded in Ukraine (Khaustov 2008) and Hungary (Dobrev and Mahunka 1991). We collected it in Western Siberia in alcohol sediments containing Ips typographus (Khaustov 2017b).

The attachment site of this species on the beetle is unknown. We collected females of S. muscocicola only in the alcohol sediments.

Material examined. Three females, Russia, Tyumen Region, Tyumen District, vicinity of settlement Uspenka, $57^{\circ} 04^{\prime} \mathrm{N}, 65^{\circ} 04^{\prime} \mathrm{E}$, in alcohol sediments containing numerous specimens of Ips typographus collected by pheromone traps, 22 May 2017, coll. A.A. Khaustov.

\section{Scutacarus palustris Rack, 1966}

(Figs. 15C, D)

This species is known from Germany, Austria, Hungary, France, Ireland, Lithuania, USA, India, and Ukraine (Khaustov 2008). Usually it inhabits wet soil and forest litter. Previously, it has never been recorded as an associate of any insect. This is the first record of this species in Russia.

The attachment site of this species on the beetle is unknown. We collected females of $S$. palustris only in the alcohol sediments.

Material examined. One female, Russia, Tyumen Region, Tyumen District, vicinity of settlement Uspenka, $57^{\circ} 04^{\prime} \mathrm{N}, 65^{\circ} 04^{\prime} \mathrm{E}$, in alcohol sediments containing numerous specimens of Ips typographus collected by pheromone traps, 5 June 2017, coll. A.A. Khaustov; 6 female, same locality, 14 June 2017.

\section{Family Tarsonemidae Iponemus gaebleri gaebleri
(Schaarschmidt, 1959)}

(Figs. 16A, B, 36E, F, 39A-D, 42B, 43C, D)

This species was described based on specimens from Germany, as an associate of Ips typographus (Schaarschmidt 1959). It has also been recorded in Austria, Poland, Switzerland, Sweden, and Japan, as an associate of Ips typographus (Lindquist 1969; Moser and Bogenschütz 1984; Moser et al. 1989; Moser et al. 1997). In Canada and the USA, this species is known in association with Ips borealis, I. perterbatus, I. engelmanni, I. oregonis, I. swainei, I. hunter, I. pilifrons, I. utahensis, and Orthotomicus sp. (Lindquist 1969). It has also been reported in Western Siberia, as an associate of Ips typographus and I. duplicatus (Khaustov et al. 2017). Iponemus gaebleri is a parasitioid of bark beetles' eggs, which affects the population of bark beetles (Figs. 42B, 43C, D). According to Balazy 


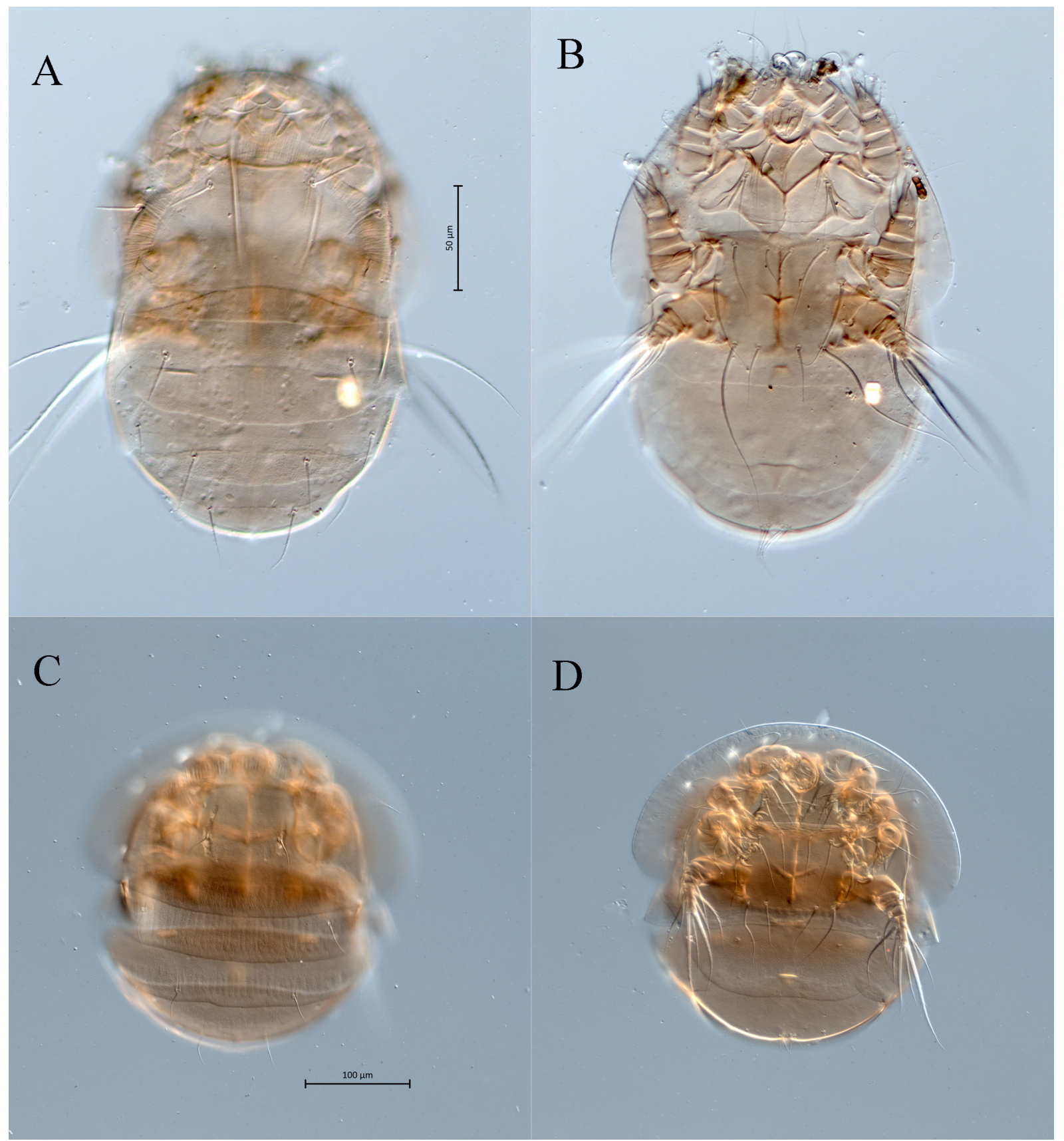

Fig. 14. A, B-Scutacarus pseudoplurisetus, female, dorsal and ventral views, respectively, C, D-Scutacarus scolyti, female, dorsal and ventral views, respectively.

and Kiełczewski (1965), in Poland, the egg mortality due to I. gaebleri varies from less than $1 \%$ to $10 \%$. Our study of egg mortality of I. typographus in the Tyumen Region confirms these data.

We collected numerous females attached to the elytral declivity of I. typographus (Figs. 36E, F, 39A-D,). However, some specimens can be phoretic under the elytra of the beetles.

Material examined: 828 females, Russia, Tyumen Region, Tyumen District, vicinity of settlement Uspenka, $57^{\circ} 04^{\prime} \mathrm{N}, 65^{\circ} 04^{\prime} \mathrm{E}$, in alcohol sediments containing numerous specimens of Ips typographus collected by pheromone traps, 22 May 2017, coll. A.A. Khaustov; 766 females, same locality, 28 May 2017; 231 females, same locality, 5 June 2017; 34 females, same locality, 14 June 2017, 12 females, same locality, 16 June 2017.

\section{Tarsonemus (s. str.) striatus Khaustov, 2017}

(Figs. 16C, D)

This species, belonging to a minimax speciesgroup, has recently been described in the Far East 


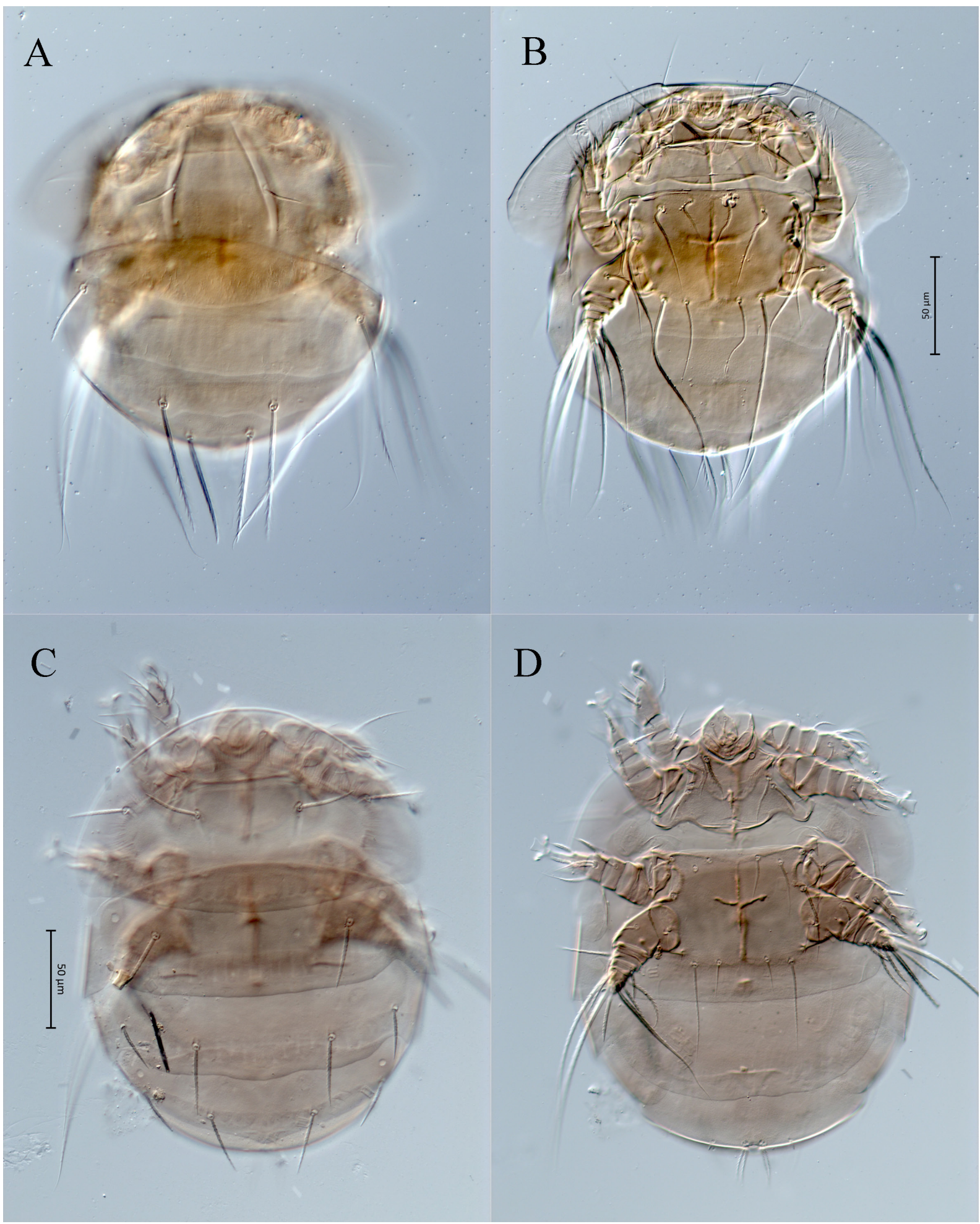

Fig. 15. A, B-Scutacarus muscocicola, female, dorsal and ventral views, respectively, C, D-Scutacarus palustris, female, dorsal and ventral views, respectively.

of Russia, where these mites were collected from the galleries of and phoretic on the four-eyed bark beetle, Polygraphus proximus (Khaustov 2017d). This is the first record of T. striatus in association with Ips typographus.
Females of $T$. striatus usually attach to the areas between the coxae of bark beetles (Khaustov 2017d).

Material examined. 30 females, Russia, Tyumen Region, Tyumen District, vicinity of settlement Uspenka, $57^{\circ} 04^{\prime} \mathrm{N}, 65^{\circ} 04^{\prime} \mathrm{E}$, in alcohol 


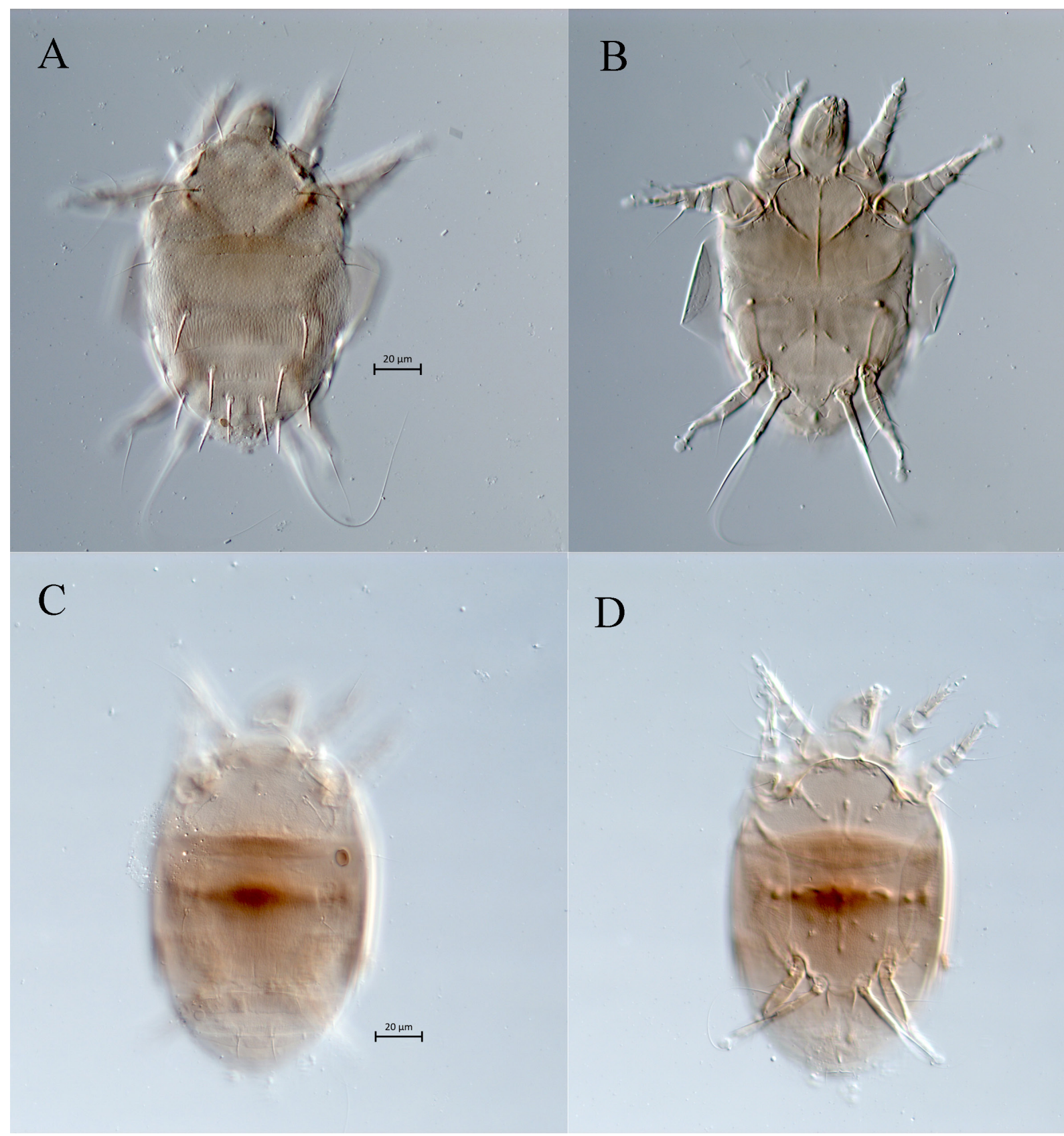

Fig. 16. A, B-Iponemus gaebleri, female, dorsal and ventral views, respectively, C, D_Tarsonemus striatus, female, dorsal and ventral views, respectively.

sediments containing numerous specimens of Ips typographus collected by pheromone traps, 22 May 2017, coll. A.A. Khaustov; 7 females, same locality, 14 June 2017, 12 females, same locality, 16 June 2017.

\section{Tarsonemus (s. str.) typographi Magowski and Moser, 2003}

(Figs. 17C, D)

This species, belonging to a minimax speciesgroup, was described in Germany and Sweden, where it was phoretic on Ips typographus (Ma- gowski and Moser 2003). This is the first record of T. typographi in Russia.

The attachment site of this species on the beetle is unknown. We collected females of $S$. palustris only in the alcohol sediments.

Material examined. 13 females, Russia, Tyumen Region, Tyumen District, vicinity of settlement Uspenka, $57^{\circ} 04^{\prime} \mathrm{N}, 65^{\circ} 04^{\prime} \mathrm{E}$, in alcohol sediments containing numerous specimens of Ips typographus collected by pheromone traps, 22 May 2017, coll. A.A. Khaustov; 24 females, same locality, 5 June 2017; 1 female, same locality, 14 June 2017. 


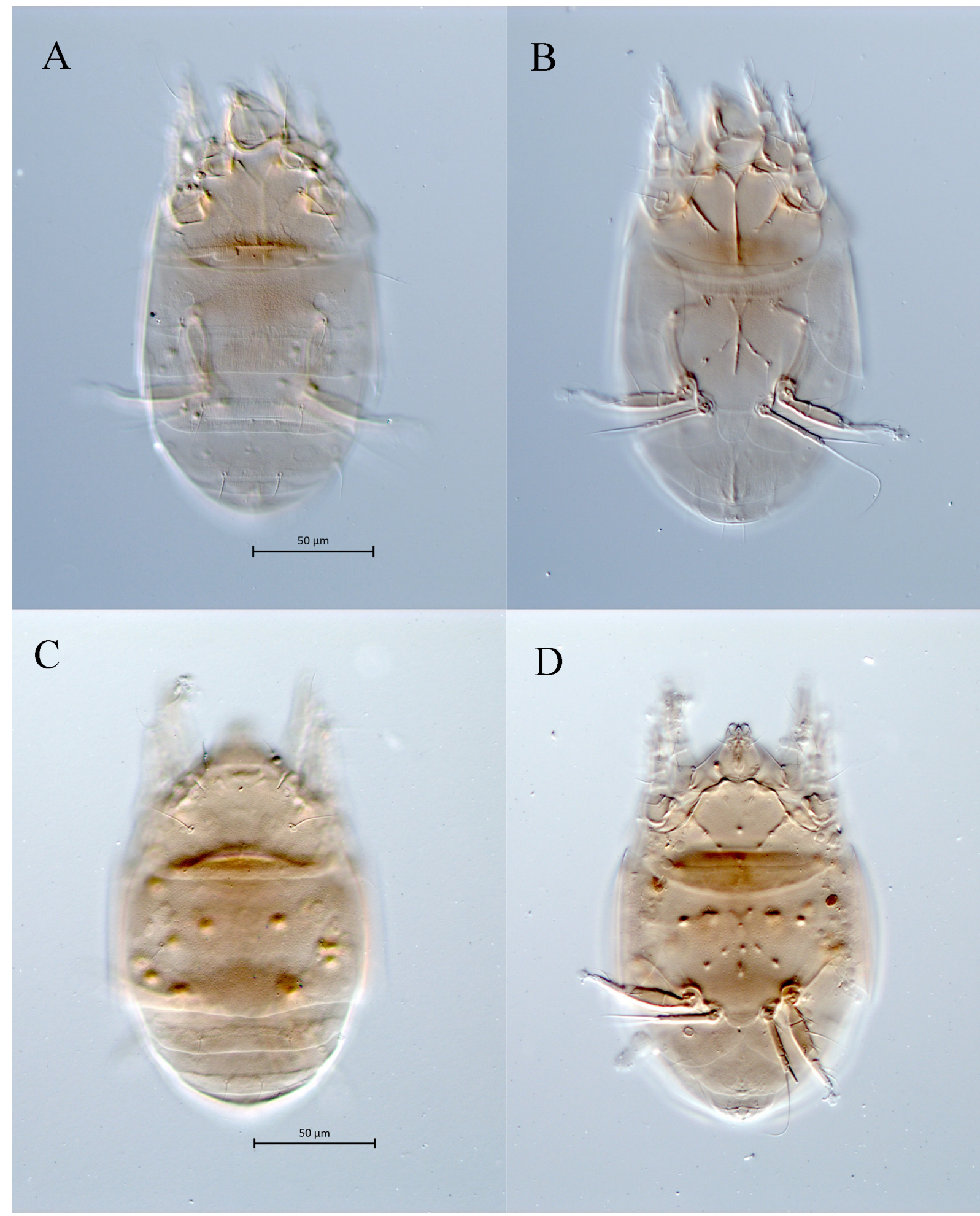

Fig. 17. A, B-Tarsonemus bistridentati, female, dorsal and ventral views, respectively, C, D_Tarsonemus typographi, female, dorsal and ventral views, respectively.

Tarsonemus (Schaarschmidtia) bistridentati Magowski and Khaustov, 2006

(Figs. 17A, B)

This species was described in Crimea, in the galleries of Pityogenes bistridentatus (Magowski and Khaustov 2006). It has also been recorded in Poland, in the galleries of Pityogenes chalcographus, Polygraphus polygraphus, Crypturgus sp., Ips typographus, Trypodendron lineatum; and in Spain and Switzerland, where it was phoretic on Ips acuminatus (Magowski 2010). Recently, it was 


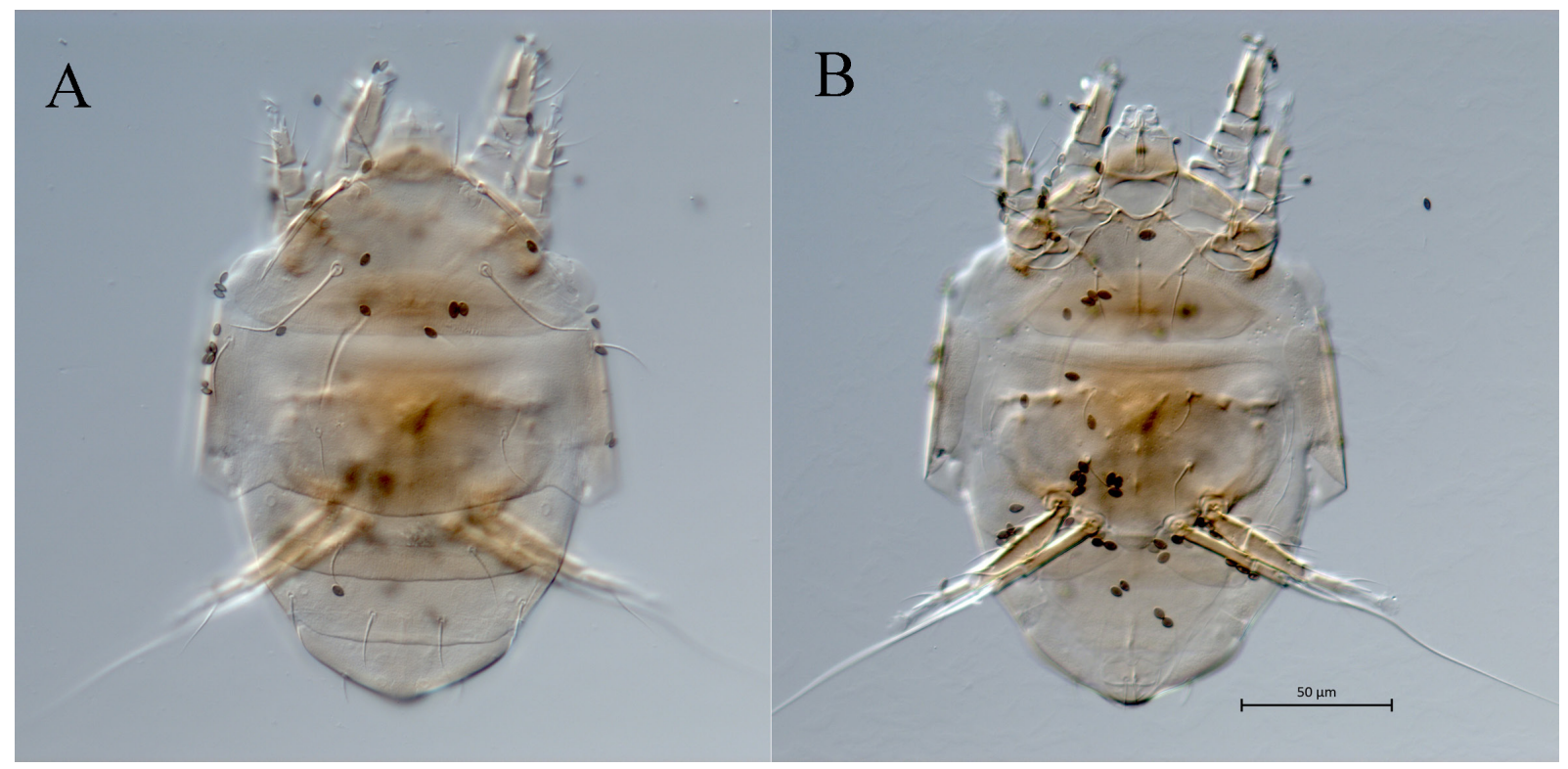

Fig. 18. A, B-Heterotarsonemus lindquisti, female, dorsal and ventral views, respectively.

found in Western Siberia, phoretic on Pityogenes chalcographus (Khaustov et al. 2016).

The phoretic behavior of this species was described by Khaustov et al. (2016).

Material examined. Two females, Russia, Tyumen Region, Tyumen District, vicinity of settlement Uspenka, $57^{\circ} 04^{\prime} \mathrm{N}, 65^{\circ} 04^{\prime} \mathrm{E}$, in alcohol sediments containing numerous specimens of Ips typographus collected by pheromone traps, 22 May 2017, coll. A.A. Khaustov.

\section{Heterotarsonemus lindquisti Smiley, 1969}

(Figs. 18A, B)

This species was described based on specimens from the USA, as an associate of the Dendroctonus frontalis bark beetle (Smiley 1969). Lindquist (1970b) redescribed this species and provided new records from the USA and Honduras from Ips cribricollis, I. kmausi, I. emarginatus, I. confusus, Dendroctonus monticolae, Trypodendron rufitarsis, and Aulonium ferrugineum. It has also been recorded in Sweden, phoretic on Ips typographus (Moser et al. 1989; Smiley and Moser 1985). This is the first record of H. lindquis$t i$ in Russia.

The attachment site of this species on the beetle is unknown. We collected females of $H$. lindquisti only in the alcohol sediments.

Material examined. Two females, Russia, Tyumen Region, Tyumen District, vicinity of settlement Uspenka, $57^{\circ} 04^{\prime} \mathrm{N}, 65^{\circ} 04^{\prime} \mathrm{E}$, in alcohol sediments containing numerous specimens of Ips typographus collected by pheromone traps, 22 May 2017, coll. A.A. Khaustov; 16 females, 6 males, 6 larvae, same locality, in the galleries of I. typographus, 5 July 2016.

\section{Order Sarcoptiformes \\ Suborder Oribatida \\ Family Scheloribatidae \\ Siculobata (Paraleius) leontonycha (Berlese, 1910)}

(Figs. 40A-F, 44A, B)

This species is distributed in the Holarctic region, in association with numerous species of bark beetles (reviewed in Ahadiyat and Akrami, 2015).

In our study, this was the most abundant species, recovered both in the galleries of and phoretic on I. typographus (Table 1). Usually, phoretic mites attach to the long hairs of the beetle, mainly on the head and thorax (Figs. 40A-F, 44A, B).

Material examined: 2,774 females, Russia, Tyumen Region, Tyumen District, vicinity of settlement Uspenka, $57^{\circ} 04^{\prime} \mathrm{N}, 65^{\circ} 04^{\prime} \mathrm{E}$, in alcohol sediments containing numerous specimens of European spruce bark beetle Ips typographus collected by pheromone traps, 22 May 2017, coll. A.A. Khaustov; 4,137 females, same locality, 28 May 2017; 1,802 females, same locality, 5 June 2017; 239 females, same locality, 14 June 2017; 281 females, same locality, 16 June 2017. 


\section{Hyporder Astigmata}

Family Acaridae

\section{Acarus sp. [short dorsal setae]}

(Figs. 19A, B)

Many species of the genus Acarus are common stored-product pests, known based on both adult and deutonymphal stages (Griffiths 1964, 1970). In natural situations, species of Acarus commonly occur in nests of rodents and birds, while deutonymphs are phoretic on their hosts' parasites, e.g. fleas (Fain and Beaucournu 1972; OConnor and Pfaffenberger 1987). Several other non-synantropic species are known from forest litter (Acarus tyrophagoides (Zachvatkin, 1941)) and old dung (Acarus mirabilis Volgin, 1965). These species are only known based on adults, whereas their deutonymphs still remain undescribed (Griffiths 1970; Volgin 1965; Zachvatkin 1941). During our research, we have found deutonymphs which could potentially belong to these species. They are distinct in having very short scapular setae, which makes them similar to the associates of vertebrate nests, Acarus nidicolous Griffiths, 1970 and Acarus monopsyllus Fain and Schwan, 1984 (Fain and Schwan 1984; Griffiths 1970). In the latter two species, the scapular setae are relatively short, yet not represented by microsetae. In our species, the scapular setae and all other dorsal setae are microsetae; coxal setae $4 b$ are situated in a posterior position - a character state similar to that of Acarus nidicolous Griffiths, 1970.

Material examined. 7 heteromorphic deutonymphs (HDNs), Russia, Tyumen Region, Tyumen District, vicinity of settlement Uspenka, $57^{\circ} 04^{\prime} \mathrm{N}$, $65^{\circ} 04^{\prime} \mathrm{E}$, alcohol sediments from pheromone traps for Ips typographus, 22 May 2017, coll. A.A. Khaustov; 1 HDN, same data, 5 June 2017.

\section{Boletoglyphus boletophagi (F. Turk and S. Turk, 1952)}

(Figs. 19B, C)

This species is known from specimens collected in the United Kingdom (Scotland) (Turk and Turk 1952), Slovakia (Samšiňák 1957), Poland (Haitlinger 2004; Haitlinger and Lupicki 2012), Finland (Penttinen et al. 2013), Siberia, and the European part of Russia (Bugrov 1997; Klimov 1998a; Volgin 1953). A similar species, Boletoglyphus extremiorientalis, occurs in eastern Russia and Japan (Klimov 1998a).
Feeding stages of $B$. boletophagi are common in the tube layers of old bracket fungi (Aphyllophorales; Polyporaceae; mainly Fomes fomentarius, which grows on birch trees) sporocarps,. The mites feed on fungal tissues and spores. Phoretic deutonymphs attach to the tenebrionid beetle Bolitophagus reticulatus (Coleoptera: Tenebrionidae), which lives in the same fungus. Occasionally, deutonymphs can be found on ciid beetles (Ciidae), whose brood also develops in bracket fungi.

Penttinen et al. (2013) reported deutonymphs of $B$. boletophagi, which were collected by Ips typographus pheromone traps in Finland. We consider this and our record as an accidental phoretic association.

Material examined. 2 HDNs, Russia, Tyumen Region, Tyumen District, vicinity of settlement Uspenka, $57^{\circ} 04^{\prime} \mathrm{N}, 65^{\circ} 04^{\prime} \mathrm{E}$, alcohol sediments from pheromone traps for Ips typographus, 5 June 2017, coll. A.A. Khaustov.

\section{Forcellinia wasmanni (Moniez, 1892)}

This is a myrmecophilous species distributed throughout the Palaearctic (Černý and Samšiňák 1971; Chmielewski 1977; Fain 1987; Kadjaia 1994; Kiełczewski and Wiśniewski 1971; Klimov 1997; Mahunka 1983; Sevastianov 1970; Türk and Türk 1957; Zachvatkin 1941). Feeding stages live in ant nests, consuming dead ants and various organic debris. Phoretic deutonymph live on adult ants (Wasmann 1897; Zachvatkin 1941). There is a single species of Forcellinia found in association Forecellinia insolita - with bark beetles that live in the USA (Woodring and Moser, 1970). Phoretic deutonymphs of this species were collected from Dendroctonus frontalis (Woodring and Moser 1970) and Ips grandicollis (Moser and Roton 1971). In addition, mites of this species were sampled from the galleries of Dendroctonus frontalis (Moser 1975). It is likely that some ant-associated species are phoretic.

Material examined. 2 HDNs, Russia, Tyumen Region, Tyumen District, vicinity of settlement Uspenka, $57^{\circ} 04^{\prime} \mathrm{N}, 65^{\circ} 04^{\prime} \mathrm{E}$, alcohol sediments from pheromone traps for Ips typographus, 22 May 2017, coll. A.A. Khaustov.

\section{Ipsoglyphus bochkovi Klimov and Khaustov, 2018}

(Figs. 20A, B)

This species has been described previously as part of our current survey (Klimov and Khaustov, 2018). 

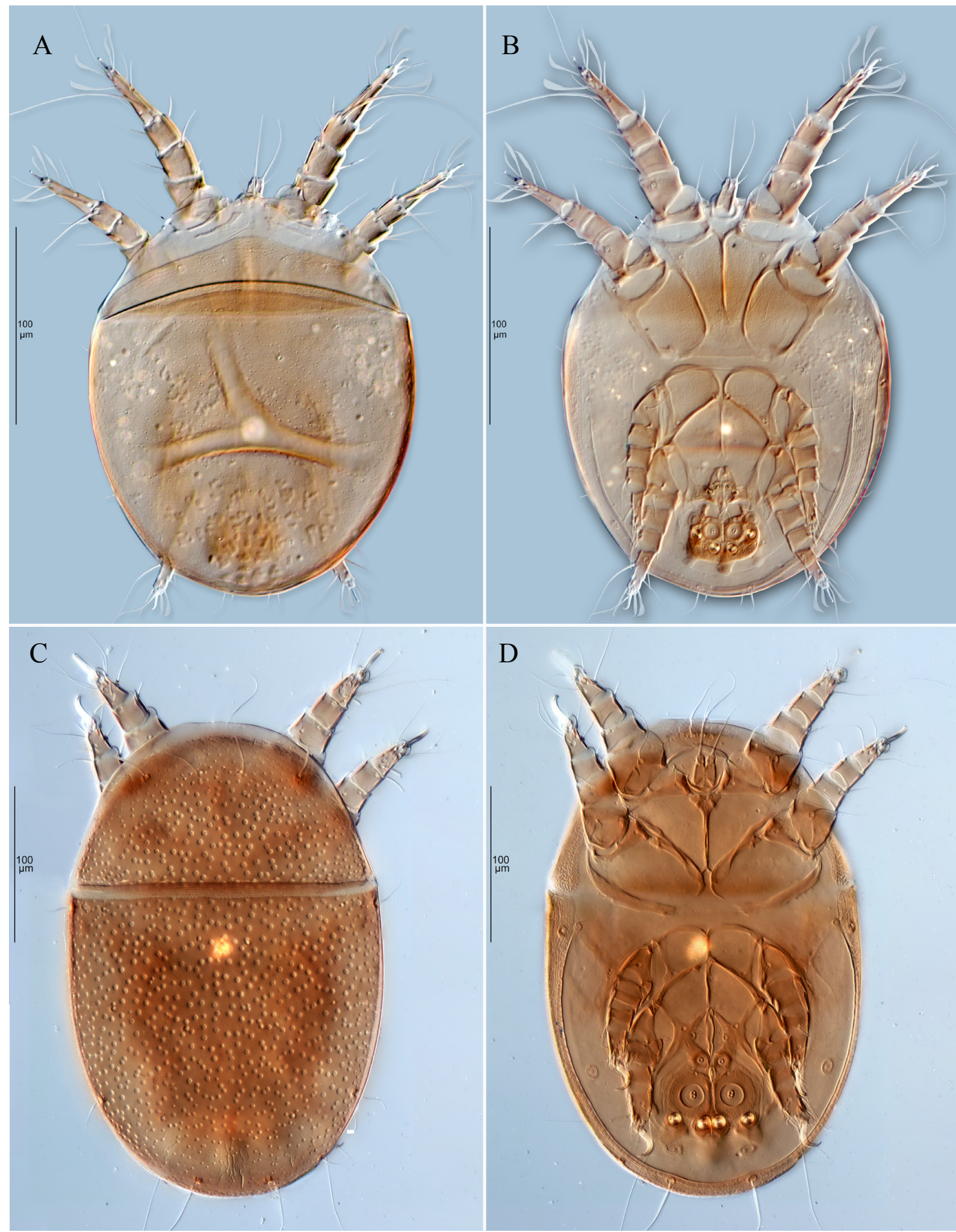

Fig. 19. A, B-Acarus sp. (short dorsal setae), phoretic deutonymph, dorsal and ventral views, respectively, C, DBoletoglyphus boletophagi, phoretic deutonymph, dorsal and ventral views, respectively.

Material examined. 38 HDNs, Russia, Tyumen Region, Tyumen District, vicinity of settlement Uspenka, $57^{\circ} 04^{\prime} \mathrm{N}, 65^{\circ} 04^{\prime} \mathrm{E}$, alcohol sediments from pheromone traps for Ips typographus, 22 May 2017, coll. A.A. Khaustov.

\section{Kuzinia laevis (Dujardin, 1849)}

This species is known from the Palaeractic region. It had been introduced to the Australian region (Australia, Tasmania, and New Zealand) with commercial bumblebee colonies used for crop 


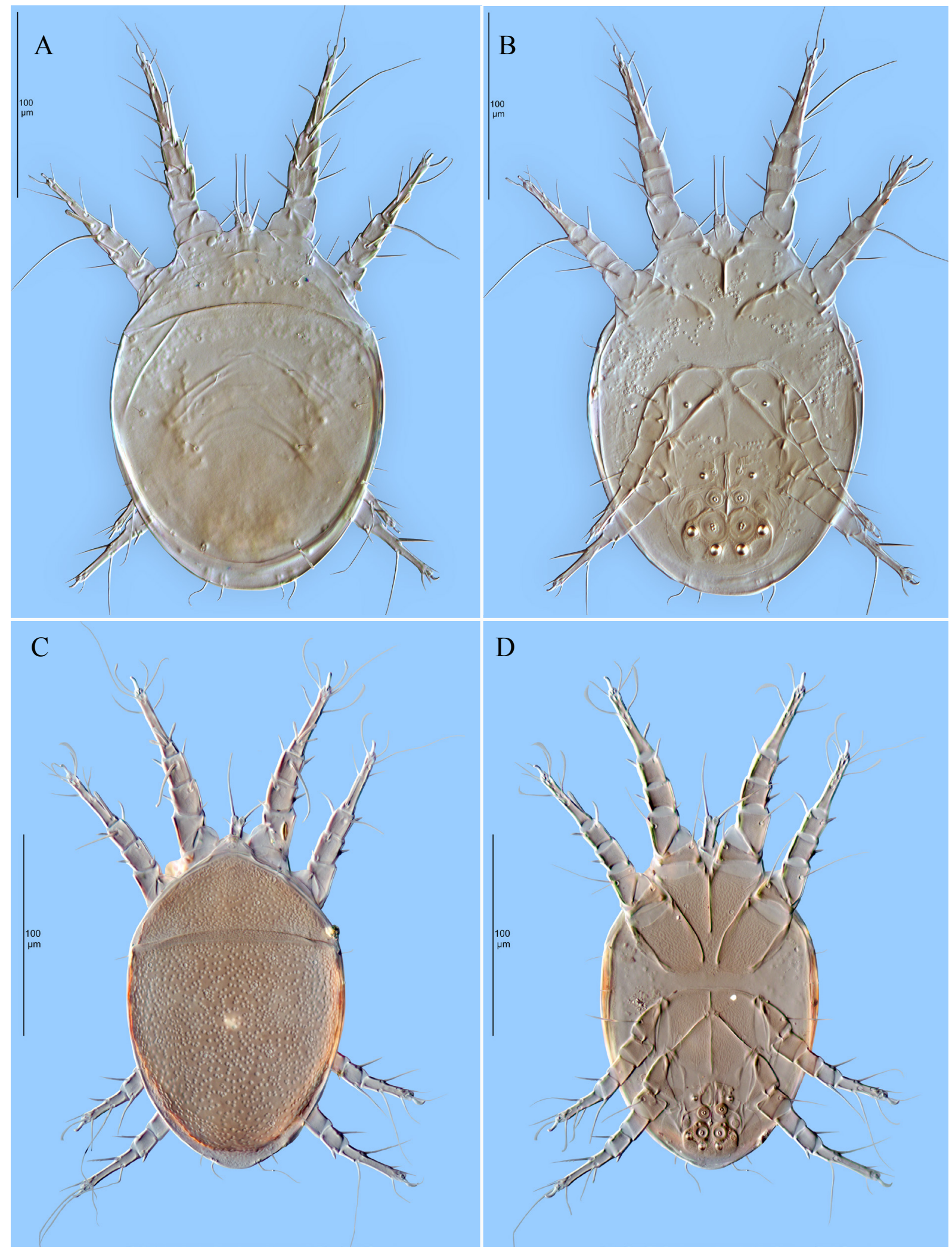

Fig. 20. A, B-Ipsoglyphus bochkovi, phoretic deutonymph, dorsal and ventral, views, respectively, C, D—Naiadacarus sp., phoretic deutonymph, dorsal and ventral views, respectively.

pollination (Halliday 2002; Macfarlane 2005). Published records of Kuzinia laevis obtained from native bumblebees from the New World, along with several other co-occurring species of Kuzinia, may be stemmed from the existing taxonomical impediment in species identification in this genus (Klimov et al. 2016). Feeding stages of Kuzinia laevis live in nests of bumblebees (Bombus spp.), 
where they feed on various organic debris, bumble bee cocoon material, honey, pollen, nematodes, and fungi (Chmielewski 1969; Grobov 1978). Occasionally, phoretic deutonymphs can be found on other bees, wasps, and other insects, as well as in rodent burrows (which can be nesting sites for bumblebees) (Klimov et al. 2016). It is likely that our mites come from a single bumblebee individual that accidentally got into the pheromone trap.

Material examined. 4 HDNs, Russia, Tyumen Region, Tyumen District, vicinity of settlement Uspenka, $57^{\circ} 04^{\prime} \mathrm{N}, 65^{\circ} 04^{\prime} \mathrm{E}$, alcohol sediments from pheromone traps for Ips typographus, 5 June 2017, coll. A.A. Khaustov.

\section{Naiadacarus sp. [granulate dorsum, long legs III-IV]}

(Figs. 20C, D)

This species has a heavily punctate dorsum, genual solenidion $\sigma$ III absent, represented an alveolus only, and long legs III-IV. Morphologically, our deutonymphs are very close to Naiadacarus fashingi OConnor, 1989, which are phoretically associated with syrphid flies in the USA. The differences between the two species include: longer setae $s c x$; and solenidion $\omega_{2}$ grouped with solenidia $\omega_{1}$ and $\omega_{3}$ in the same cluster $\left(\omega_{2}\right.$ situated at base of tarsus, proximally from $\omega_{1}+\omega_{3}$ cluster in $N$. fashingi). The most common hosts of $N$. fashingi, syrphid flies Brachypalpus oarus and Chalcosyrphus sp., live in subcortical spaces and in decaying wood as larvae. Mite deutonymphs presumably attach to female flies during oviposition, as evidenced by the predominant presence of mites on females in most host species (OConnor 1989). We expect that our species lives in subcortical habitats as well. This is the first record of the genus Naiadacarus in Russia (see below).

Remark. In North America, Naiadacarus arboricola live in water-filled treeholes, feeding on submerged, skeletonizing, decaying leaves (Fashing 1975). Deutonymphs of $N$. arboricola are phoretic on syrphid flies (mostly the Mallota genus), whose larvae develop in the same habitat. Other North American mite species, N. fashingi and N. mydophilus, are known based only on deutonymphs' description. Based on the biology of phoretic hosts, these mites may inhabit wet decaying wood and/or moist (rather than water-filled) treeholes (OConnor 1989). Furthermore, an undescribed species was reported from a bromeliad in Guatemala (Okabe and OConnor 2001). In the Old World, Naiadacarus nepenthicola was described based on adults and deutonymphs collected in Brunei from fluid-filled pitcher-plants Nepenthes bicalcarata. This mite probably feeds on decomposing leaves that fall into pitchers as well as on decomposing insects trapped by pitchers. Deutonymphs of this species are phoretic on the Campanotus schmitzi ant, which inhabits exclusively the hollow tendrils of $N$. bicalcarata pitchers (Fashing and Chua 2002). Finally, feeding stages of an undescribed species of Naiadacarus have been reported based on specimens recovered from a water-filled hole in a tree stump in Austria (Wurst 2006).

Material examined. $31 \mathrm{HDNs}$, Russia, Tyumen Region, Tyumen District, vicinity of settlement Uspenka, $57^{\circ} 04^{\prime} \mathrm{N}, 65^{\circ} 04^{\prime} \mathrm{E}$, alcohol sediments from pheromone traps for Ips typographus, 22 May 2017, coll. A.A. Khaustov; $1 \mathrm{HDN}$, same data, 28 May 2017; 11 HDNs, same data, 5 Jule 2017.

\section{Schwiebea sp. eurynympha-group [punctate dorsum]}

(Figs. 21A, B)

This morphospecies belongs to the eurynympha-group. It is distinct from all species in the eurynympha-group by the punctate dorsal idiosoma. It is different from Schwiebea eurynympha (Oudemans, 1911) in: 1) ovoid coxal setae $4 a$ (transversely elongated in S. eurynympha); and 2) setae $s i$ being situated posteriorly to setae se (vs. being situated on the same transverse level in S. eurynym$p h a$ ). By the shape of coxal setae $4 a$ and the position of the scapular setae, this species is similar to Schwiebea tshernyshevi Zachvatkin, 1941 and Schwiebea stammeri Wurst, 2002 (the deutonymph of $S$. stammeri was described in Türk and Türk (1957) as S. "eurynymphae"). Schwiebea tshernyshevi has been synonymized with Uropoda parallela Müller, 1860 by Samšiňák (1958). However, as evidenced by the morphology of legs I-II, Müller's Figures 3 a-d (Müller 1859 (1860)) actually show a histiostomatid. We, therefore, do not accept this synonymy.

Schwiebea stammeri was cited to differ from $S$. tshernyshevi by subequal setae $e_{2}$ and $h_{2}$ in males (Wurst 2002). However, these setae are also subequal in males of $S$. tshernyshevi (Zachvatkin 1941: Figs. 344, 345). Zachvatkin's text indeed compares setae sae $\left(=f_{2}\right)$ and $l p\left(=e_{2}\right)$ (lp 2 times shorter than sae, p. 201), despite the absence of sae was cited as diagnostic to Schwiebea (p. 197). The short setae on Fig. 344 are attributable to " $f$ " of general- 


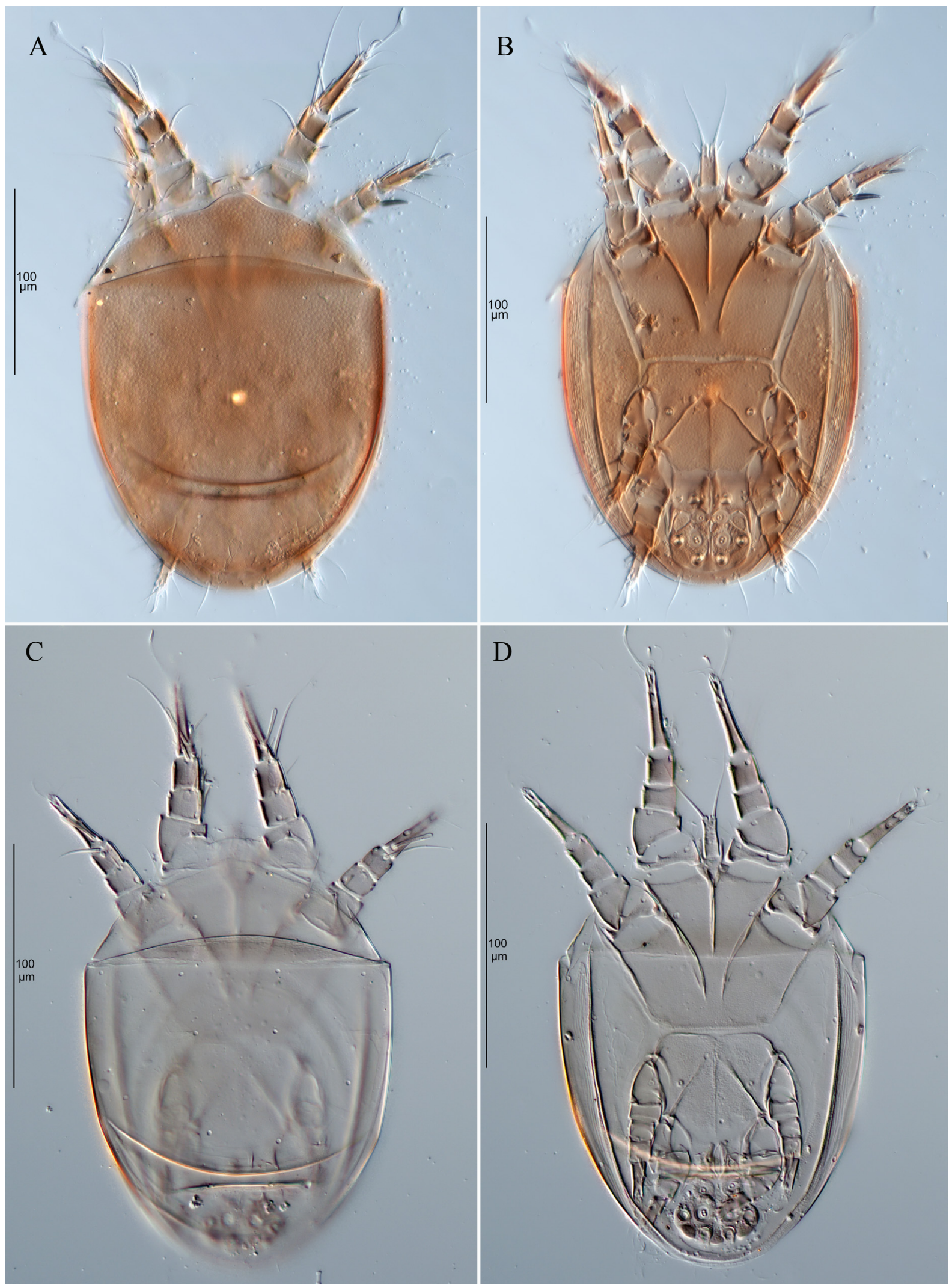

Fig. 21. A, B-Schwiebea sp. eurynympha-group (punctate dorsum), phoretic deutonymph, dorsal and ventral views, respectively, C, D_Schwiebea sp. eurynympha-group (small, unsclerotized, $1 a$ and $3 a$ filiform), phoretic deutonymph, dorsal and ventral views, respectively.

ized acarid (but not Schwiebea), while the typical setae $e_{2}$ was also present on this figure. This sug- gests that the short setae on Fig. 344 are probably non-existent and represent an artifact. Designation 
of a neotype for $S$. tshernyshevi is needed to solve the status of Schwiebea stammeri.

Material examined. 1HDN, Russia, Tyumen Region, Tyumen District, vicinity of settlement Uspenka, $57^{\circ} 04^{\prime} \mathrm{N}, 65^{\circ} 04^{\prime} \mathrm{E}$, alcohol sediments from pheromone traps for Ips typographus, 22 May 2017, coll. A.A. Khaustov.

\section{Schwiebea sp. eurynympha-group [small, unsclerotized, 1a, 3a filiform]}

(Figs. 21C, D)

This species has broadly parallel posterior borders of coxal fields II and IV (as in the eurynym$p h a$-group) and filiform coxal setae $1 a$ and $3 a$. This is a small and weakly sclerotized species.

Material examined. $1 \mathrm{HDN}$, Russia, Tyumen Region, Tyumen District, vicinity of settlement Uspenka, $57^{\circ} 04^{\prime} \mathrm{N}, 65^{\circ} 04^{\prime} \mathrm{E}$, alcohol sediments from pheromone traps for Ips typographus, 5 June 2017, coll. A.A. Khaustov.

\section{Schwiebea nesbitti}

\section{F. Türk and E. Türk, 1957}

(Figs. 22A, B)

This species is known from females and phoretic deutonymphs collected in Germany, Austria, Belgium, and Poland (Haitlinger 1988; Türk and Türk 1957; Wurst 2002; Wurst and Frank 1998). We record it for the first time for Russia. It is probably parthenogenetic, since males have not been found (Wurst 2002; Wurst and Frank 1998). Feeding stages live in deeper layers of rotten wood, especially in rotten tree stumps (Wurst and Frank 1998). Heteromorphic deutonymphs are phoretic on the following arthropods: Dorcus parallelipipedus (Lucanidae), Melanotus rufipes (larvae) (Elateridae), Pterostichus anthracinus (Carabidae), Carabus glabratus (Carabidae), Serviformica fusca (Formicidae), Unciger foetidus (Julidae) (Haitlinger 1988; Türk and Türk 1957; Wurst 2002; Wurst and Frank 1998), and Ips typographus (our data).

Remark. Schwiebea nesbitti is likely to be a junior synonym of Schwiebea pachyderma Zachvatkin, 1941 known from females collected in Ukraine and Russia (Zachvatkin 1941). Females of S. pachyderma have a strongly sclerotized, browncolored idiosoma and indistinguishable boundaries of the propodosomal shield. These character states are diagnostic for $S$. nesbitti and distinguish both S. pachyderma and S. nesbitti from Schwiebea talpa Oudemans, 1916 (idiosoma not sclerotized, propodosomal shield with distinct boundaries). However, in S. pachyderma, seta $m G$ on genu I was originally figured elongated and not thorn-shaped (setae $m G$ I-II are thorn-shaped in S. nesbitti and elongated in $S$. talpa). The former two character states (idiosomal sclerotization, prodorsal shield) are easily observable and were mentioned in the original description of S. pachyderma, while the latter character state (the shape of $m G$ I-II) is a relatively difficult to observe with precision. Additional research is needed to verify the status of $S$. pachyderma.

Our specimens differ from the most recent redescription of Schwiebea nesbitti (Wurst and Frank 1998) by the absence of fine pectinations of $k T$ III and $r$ IV (present in $S$. nesbitti) and the prodorsum covered with small and faint dimples in contrast to the hysteronotum (both propodorsum and hysteronotum lack dimples in $S$. nesbitti).

Material examined. 2 HDNs, Russia, Tyumen Region, Tyumen District, vicinity of settlement Uspenka, $57^{\circ} 04^{\prime} \mathrm{N}, 65^{\circ} 04^{\prime} \mathrm{E}$, alcohol sediments from pheromone traps for Ips typographus, 28 May 2017, coll. A.A. Khaustov.

\section{Schwiebea nova (Oudemans, 1906)}

(Figs. 22C, D)

This species has been originally described from specimens obtained in Germany (Oudemans 1906) and then was reported in various localities in the Holarctic region. Feeding stages are subcortical, living under the bark of dead trees and feeding on decaying plant material and fungal hyphae. Deutonymphs are commonly found on various arthropods that visit rotten wood, predominantly beetles (reviewed Hutcheson et al. 2015). Among bark beetles, it has been recorded from Tomicus piniperda in Poland (Michalski and Ratajczak 1989) and Scolytus ratzeburgi in Russia (Ermilov et al. 2007). This species may be difficult to identify accurately (see below).

Remark. Schwiebea nova was briefly described as Tyroglyphus novus based on a deutonymph collected in Bremen, Germany (Oudemans 1906). Later, a more detailed and illustrated description appeared (Oudemans 1907). Tyroglyphus novus was designated as the type species of a new deutonymphal genus Troupeauia Zachvatkin, 1941 (Zachvatkin 1941). However, when adults have been discovered, this genus was placed into synonymy of Schwiebea Oudemans, 1916 (Türk and Türk 1957). Unfortunately, the sample of Türk and Türk (1957) contained two similar species, with and without tibial setae $h T$ I-II. Schwiebea nova (no setae $h T$ I-II) 
was redescribed from deutonymphs and adults from Russia (Klimov 1998b). A similar species has been reported from adults and deutonymphs from Germany as "nG-Art3" (Wurst 2002).

In the genus Schwiebea, Wurst (2002) proposed the nova species group having filiform tarsal setae $l a$ I-II. Because he dismissed the conventional subdivision of Schwiebea into groups with one (Schwiebea s.str.) or two genual solenidia ( $\sigma$ ' and $\sigma$ ") (Megninietta, Jakotietta) in feeding stages, his nova-group included a mix of species presenting both of these character states: S. nova (Oudemans, 1906) $(2 \sigma, h T$

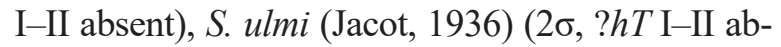
sent), S. rossica Zachvatkin, 1941 (2б, hT I-II ab-

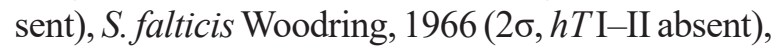

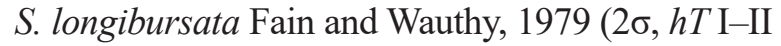
absent), S. subterranea Fain, 1982 (2б, hT I-II present), S. cepa Karg, 1987 (2б, ?), S. montana Bugrov,

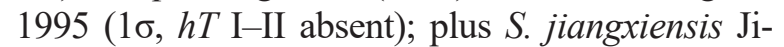

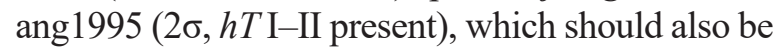
placed here. In addition, Wurst (2002) identified nine undescribed morphospecies from Central Europe and reported intermediate populations between some of them. Based on this evidence, he suggested that breeding experiments and DNA sequence data are needed to resolve the species boundaries in the novagroup. No key to species of the nova group was, therefore, provided in Wurst (2002). Here, we use an old species concept, and call the species with a single setae $g T$ I-II on tibia I-II ( $h T$ I-II are absent) in all stages $S$. nova. A similar species, having two setae on tibia I-II ( $g T$ I-II and $h T$ I-II) in all stages is called here Schwiebeia sp.1 (=S. longibursata sensu Klimov (1998b)). Types of Schwiebeia longibursata have a single tibial setae (Wurst 2002). We recognize that careful morphological examination, as well as a correlation of feeding and deutonymphal stages, along with molecular data are needed. Therefore, we consider our species assignments putative.

Material examined. $154 \mathrm{HDNs}$, Russia, Tyumen Region, Tyumen District, vicinity of settlement Uspenka, $57^{\circ} 04^{\prime} \mathrm{N}, 65^{\circ} 04^{\prime} \mathrm{E}$, alcohol sediments from pheromone traps for Ips typographus, 22 May 2017, coll. A.A. Khaustov; 49 HDNs, same data, 28 May 2017; 31 HDNs, same data, 5 June 2017; 5 HDNs, same data, 15 June 2017; 1 HDN (slide 71), same data, 16 June 2017; 1 HDN, same data, June 2017.

\section{Schwiebea sp.1 nova-group [two tibial setae, regular attachment organ]}

(Figs. 23A, B)

Remark. This morphospecies has two setae on tibia I-II ( $g T$ I-II and $h T$ I-II) and corresponds to our earlier interpretation of $S$. longibursata sensu Klimov (1998b). Types of Schwiebeia longibursata, however, have a single tibial setae (Wurst 2002). Similarly to $S$. nova, this species may be difficult to identify accurately (see above for $S$. nova).

Material examined. 18 HDNs, Russia, Tyumen Region, Tyumen District, vicinity of settlement Uspenka, $57^{\circ} 04^{\prime} \mathrm{N}, 65^{\circ} 04^{\prime} \mathrm{E}$, alcohol sediments from pheromone traps for Ips typographus, 22 May 2017, coll. A.A. Khaustov; 3 HDNs, same data, 28 May 2017; 12 HDNs, same data, 5 June 2017.

\section{Schwiebea sp. nova-group [two tibial setae, wide attachment organ]}

$$
\text { (Figs. 23C, D) }
$$

This morphospecies belongs to the nova-group. It has two setae on tibia I-II ( $g T$ I-II and $h T$ I-II). The attachment organ is distinctly wider than in the previous species.

Material examined. 3 HDNs, Russia, Tyumen Region, Tyumen District, vicinity of settlement Uspenka, $57^{\circ} 04^{\prime} \mathrm{N}, 65^{\circ} 04^{\prime} \mathrm{E}$, alcohol sediments from pheromone traps for Ips typographus, 22 May 2017, coll. A.A. Khaustov; 1 HDN, same data, 15 June 2017; 1 HDN, same data, 16 June 2017.

\section{Schwiebea sp nova-group [granulate dorsum, short legs III-IV]}

(Figs. 24A, B)

This morphospecies belongs to the nova-group. It is distinct by a well-punctate dorsum and a wider attachment organ.

Material examined. 3 HDNs, Russia, Tyumen Region, Tyumen District, vicinity of settlement Uspenka, $57^{\circ} 04^{\prime} \mathrm{N}, 65^{\circ} 04^{\prime} \mathrm{E}$, alcohol sediments from pheromone traps for Ips typographus, 22 May 2017, coll. A.A. Khaustov; $1 \mathrm{HDN}$, same data, 28 May 2017.

\section{Schwiebea scheucherae F. Türk and E. Türk, 1957}

(Figs. 24C, D)

This species is known from adults and deutonymphs collected in Germany, Austria, France, Belgium, Poland, Romania, Slovakia, Hungary, Ukraine, and Russia (Bugrov 1995; Fain 1977; Haitlinger 1988; Mahunka 1961; Sevastianov 1970; Türk and Türk 1957; Wurst 2002). Feeding stages are frequently found under moist, decomposing bark and in rotten wood. Deutonymphs are phoretic on Craspedosoma rawlinsii alemannicum (Craspedo- 


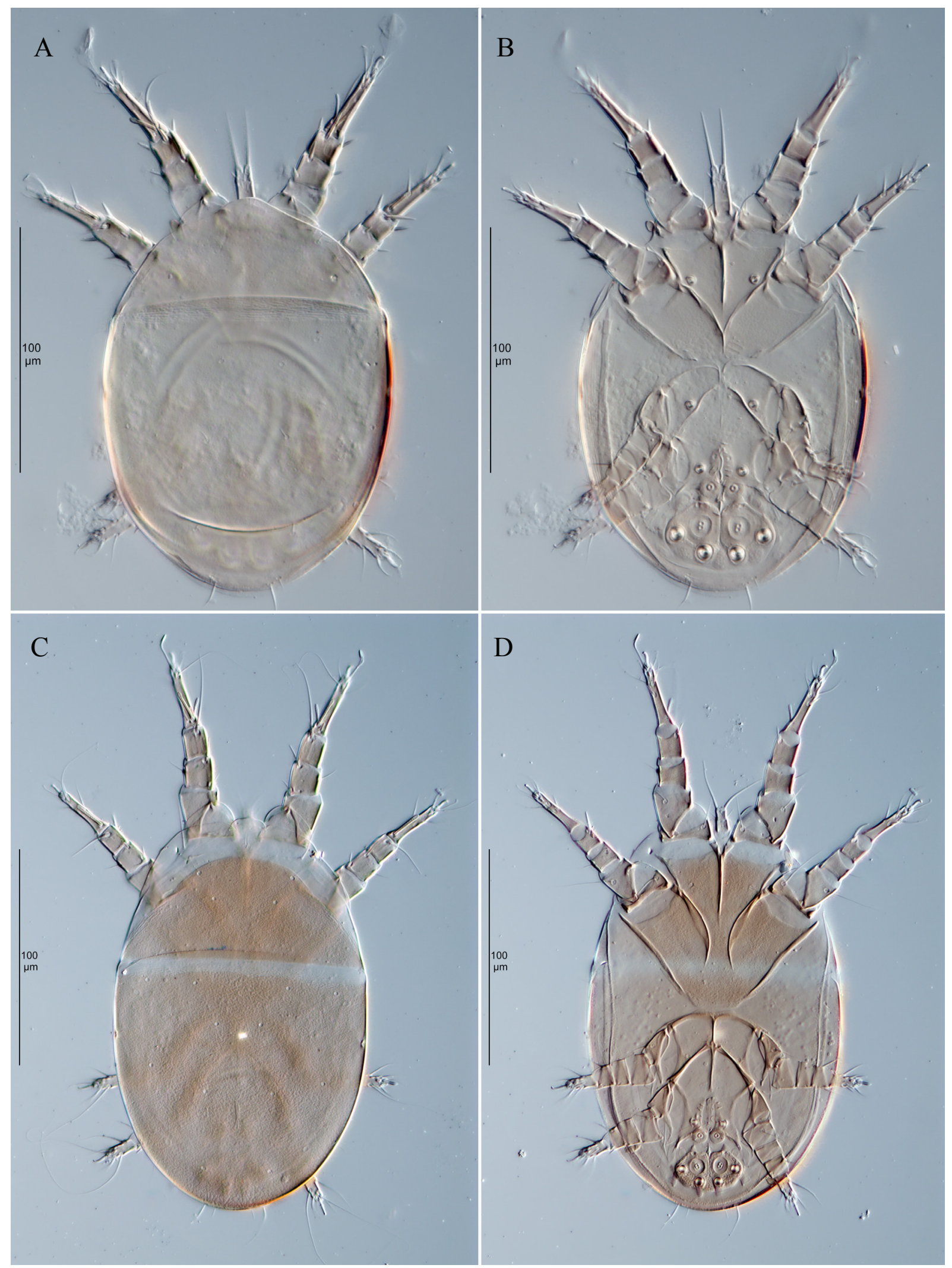

Fig. 22. A, B-Schwiebea nesbitti, phoretic deutonymph, dorsal and ventral views, respectively, C, D-Schwiebea nova, phoretic deutonymph, dorsal and ventral views, respectively.

somatidae), Julus scandinavius (Julidae), Carabus hortensis (Carabidae), Camponotus ligniperdus, Lasius niger, Lasius fuliginosus, Formica rufa (For- micidae) (Haitlinger, 1988; Kiełczewski and Wiśniewski, 1971; Sevastianov, 1970; Türk and Türk, 1957) and Ips typographus (our data). 


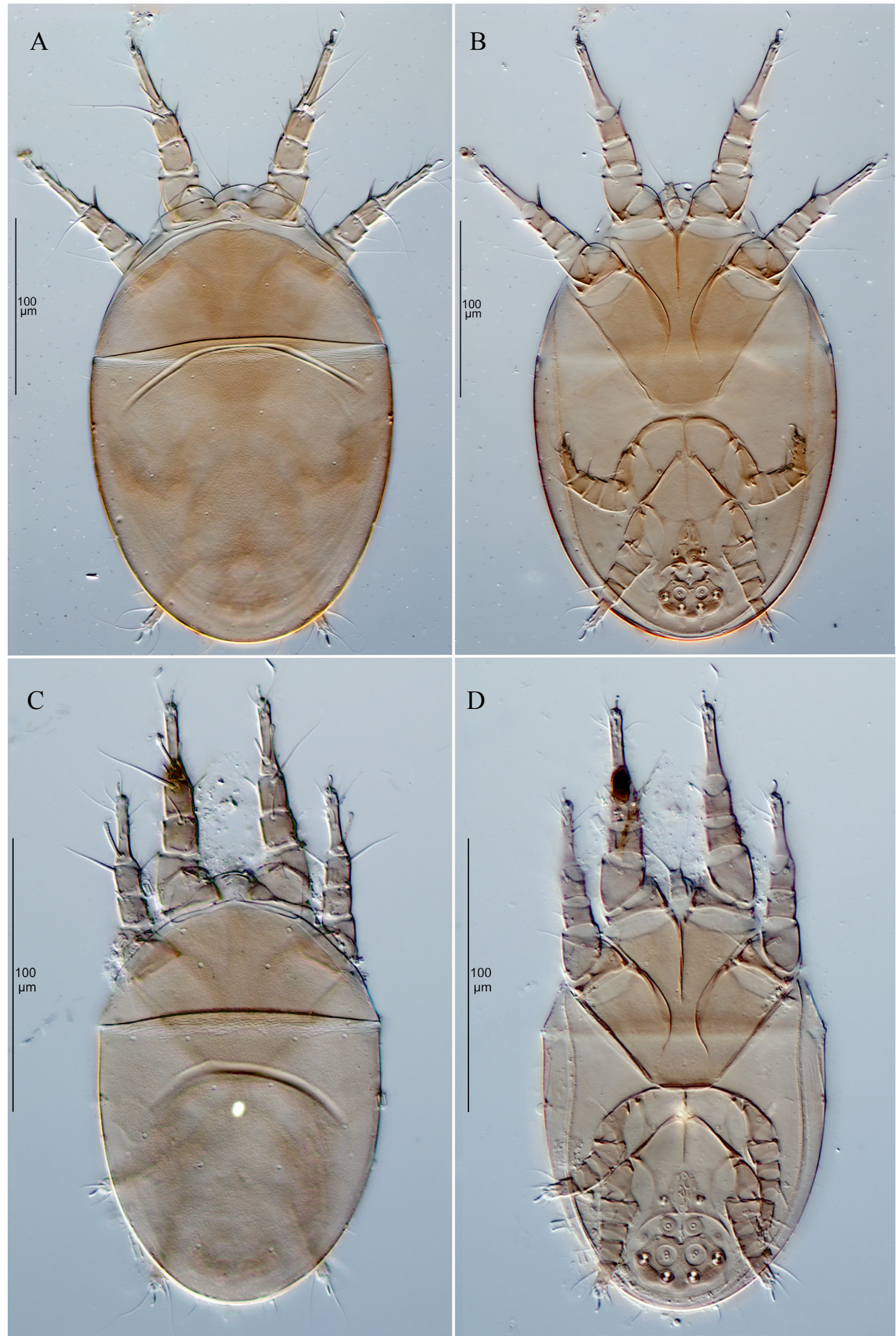

Fig. 23. A, B-Schwiebea sp. nova-group (two tibial setae, regular attachment organ), phoretic deutonymph, dorsal and ventral views, respectively, C, D-Schwiebea sp. nova-group (two tibial setae, wide attachment organ), phoretic deutonymph, dorsal and ventral views, respectively. 


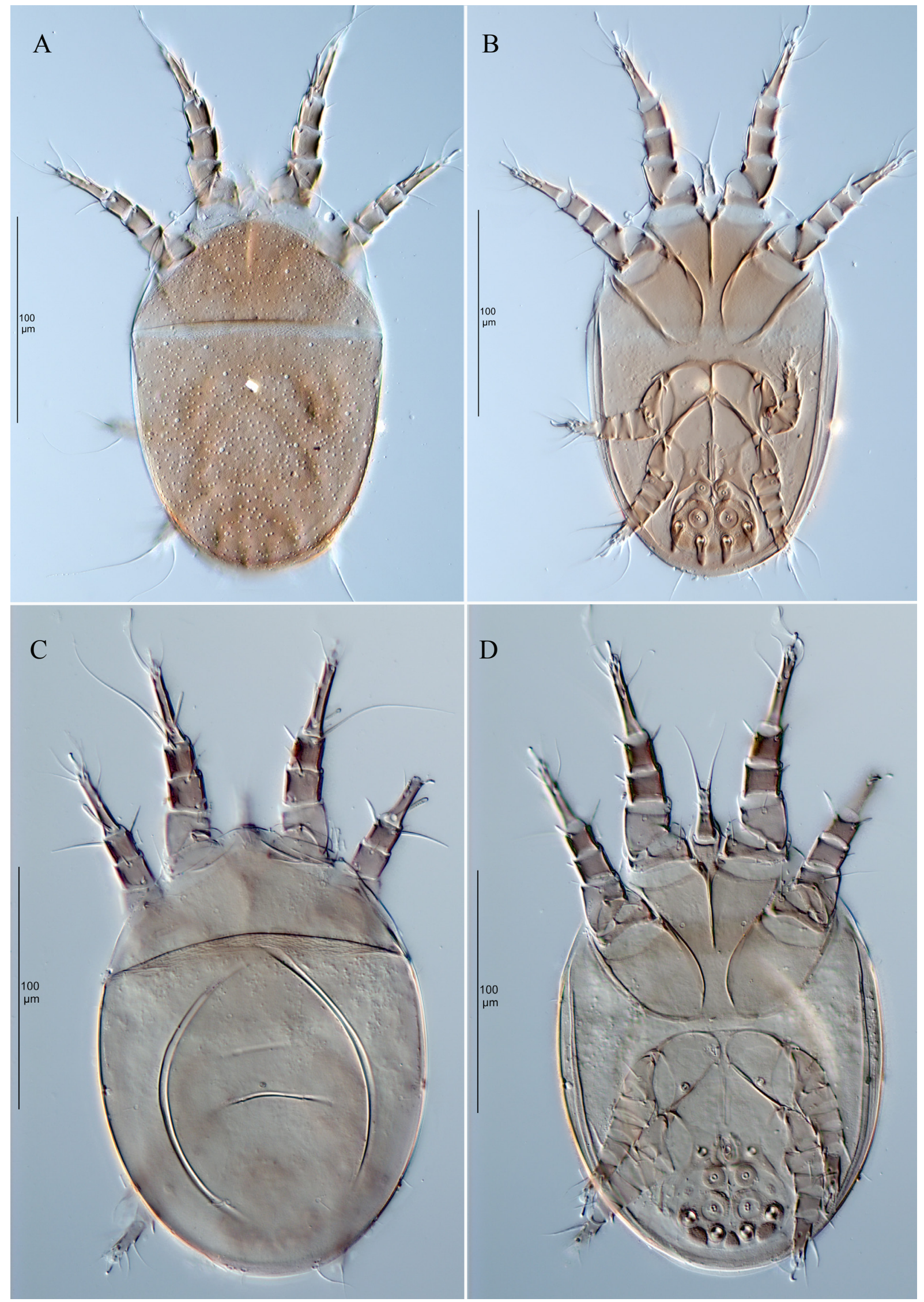

Fig. 24. A, B-Schwiebea sp. nova-group (granulate dorsum, short legs III-IV), phoretic deutonymph, dorsal and ventral views, respectively, C, D-Schwiebea scheucherae, phoretic deutonymph, dorsal and ventral views, respectively. 
Our specimens differ from the most recent redescription of Schwiebea scheucherae (Wurst 2002) by the gnathosoma being longer and wider at the base than at the tip. It is possible that the perceived differences result from the orientation of the gnathosoma in the illustration of this specimen by Wurst (2002).

Material examined. $1 \mathrm{HDN}$, Russia, Tyumen Region, Tyumen District, vicinity of settlement Uspenka, $57^{\circ} 04^{\prime} \mathrm{N}, 65^{\circ} 04^{\prime} \mathrm{E}$, alcohol sediments from pheromone traps for Ips typographus, 16 June 2017, coll. A.A. Khaustov (vial 20); 2 HDNs, same data, 15 June 2017; 1 HDN, same data, 5 June 2017.

\section{Thyreophagus corticalis (Michael, 1885)}

(Figs. 25A, B)

This is a widely distributed species known from the Palearctic and Australian regions: England (Michael 1885), Italy (Castagnoli et al. 1994; Simoni et al. 2014), France (Fain and Beaucournu 1993), Belgium (Fain 1982), Germany (Moser and Bogenschütz 1984), Netherlands (Oudemans 1924), Poland (Chmielewski 1977; Haitlinger 1988), Hungary (Ripka et al. 1999; Ripka and Szabo 2010), Slovakia (Mašán 1999), Sweden (Moser et al. 1989), Ukraine (Sevastianov 1970), Russia (Bugrov 1997; Klimov and Tolstikov 2011), and Australia (Domrow 1992).

Feeding stages have been found under the epidermis of dead stems of Phragmites communis (Michael 1903) and under the bark of numerous (31) tree species(Ripka et al. 1999), including a dead apple tree (Fain 1982). The feeding stages have also been recovered from inside the nuts of Asian hazel Corylus heterophylla (our data); beech forest soil (Fain 1982); as well as nests of the following birds: Columba palumbus, Apus apus, "aquatic bird" (Fain 1982), Puflnus tenuirostris (Domrow 1992). They have also been identified in association with Chionaspis salicis (Diaspididae) and Phylloxerina populi (Phylloxeridae) (Ripka and Szabo 2010); on various materials in beehives of Apis mellifera, including debris, bee bread, pollen, combs/wax, fungi (mold) (Chmielewski 1977, 1991). Feeding stages have also been recorded on the edible dormouse Clis glis (phoretic mite female) (Fain 1982). Deutonymphs are phoretic on various arthropods, such as springtail Allacma fusca (Sminthuridae), Oiceoptoma thoracicum beetles (Mašán 1999), Carabus arcensis (Haitlinger 1988), C. granulatus (Haitlinger 1988), C. coriaceus (Haitlinger 1988), Helops lanipes (Türk and Türk 1957). They are also phoretic on red wood ants Formica rufa (Kiełczewski and Wiśniewski 1971; Sevastianov 1970; Türk and Türk 1957); on Lasius fuliginosus, Myrmica ruginodis (Kiełczewski and Wiśniewski 1971); on parent bugs Elasmucha grisea (Pentatomidae) (Fain and Baugnee 1996); on the flea Ceratophyllus columbae, which is in turn parasitic on rock doves Columba livia (Fain and Beaucournu 1993). Bark beetle hosts include Hylurgops palliatus and Pityogenes chalcographus in Poland (Kiełczewski and Wiśniewski 1980); as well as Ips typographus in Germany and Sweden (Moser and Bogenschütz 1984; Moser et al. 1989).

Thyreophagus corticalis may play a role in spontaneous recovery of chestnuts (Castanea sativa) from a fungal disease known as chestnut blight. This disease is caused by the virulent strains of a pathogenic fungus Cryphonectria parasitica. Hypovirulent fungal strains contain a hypovirus and lose their pathogenicy. Viral double-stranded RNA from the hypovirulent mycelia can be ingested by the mites or carried on their cuticles. The RNA can subsequently be transmitted to the mycelia of virulent strains. This process causes their conversion to a hypovirulent strain, resulting in the recovery of the host tree fromchestnut canker (Simoni et al. 2014).

This mite can also be a vector of several spruce pathogens, such as Ophiostoma bicolor and Ophiostoma europhioides. Ascospores of these fungi have been found to be hyperphoretic on deutonymphs of Thyreophagus corticalis (Moser, Perry et al. 1989). Although these fungal species can kill considerable portions of the phloem, they do not cause discoloration of the sapwood (Kirisits 1998).

Material examined. 1 HDNs, Russia, Tyumen Region, Tyumen District, vicinity of settlement Uspenka, $57^{\circ} 04^{\prime} \mathrm{N}, 65^{\circ} 04^{\prime} \mathrm{E}$, alcohol sediments from pheromone traps for Ips typographus, 15 June 2017, coll. A.A. Khaustov.

\section{Thyreophagus entomophagus (Laboulbène and Robin, 1862)}

$$
\text { (Figs. 25C, D) }
$$

This is probably a cosmopolitan species. It has been reported from the following countries (a noninclusive list): France (type locality) (Laboulbène and Robin 1862); Spain (Iglesias-Souto et al. 2009); Italy (Goracci et al. 1985), including Sicily (Fumouze and Robin 1867); England (Fain 1982; Michael 1903; Newstead and Morris 1920); Germany (Fain 1982); Belgium (Fain 1982) the Czech 


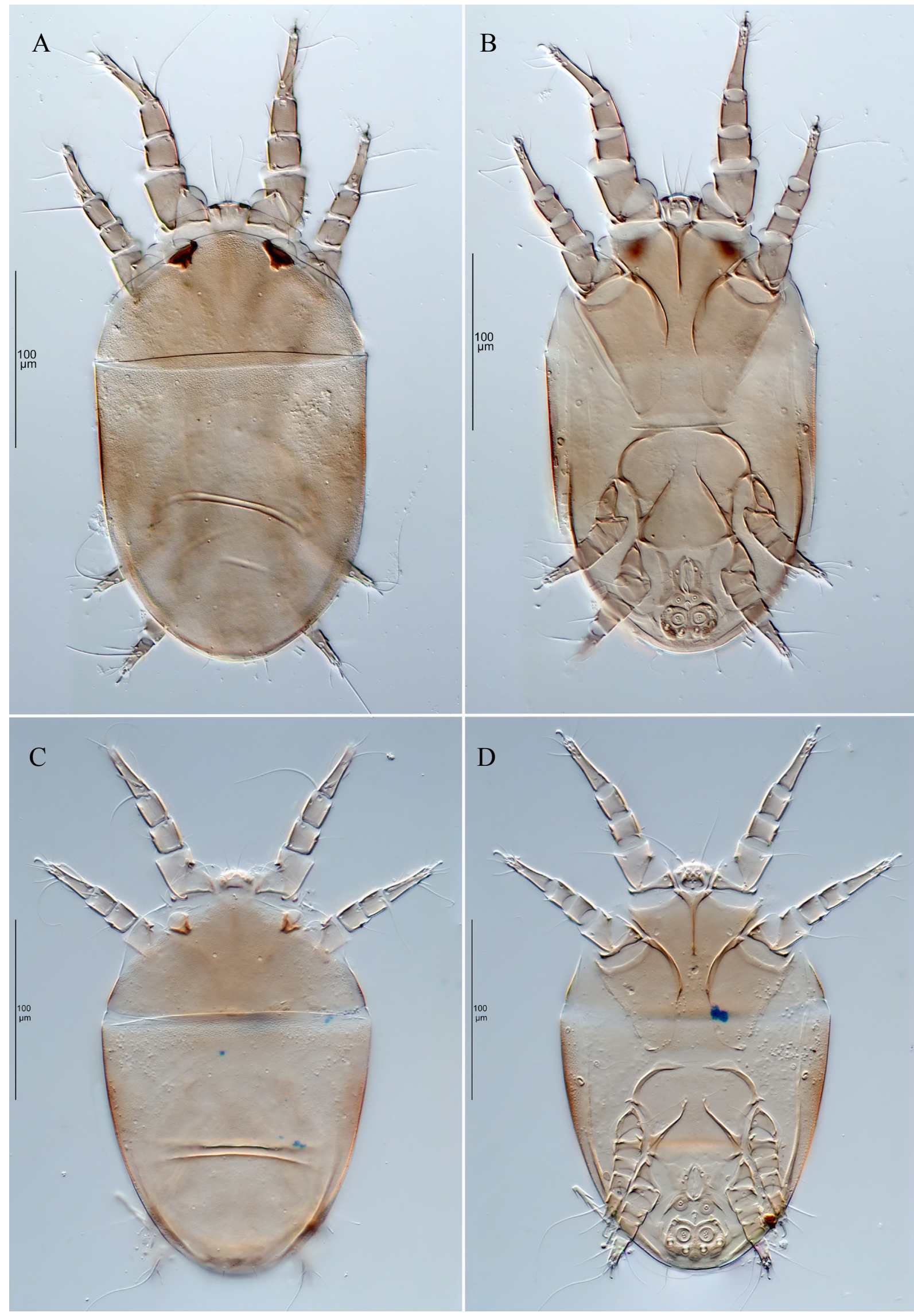

Fig. 25. A, B-Thyreophagus corticalis, phoretic deutonymph, dorsal and ventral views, respectively, C, DThyreophagus entomophagus, phoretic deutonymph, dorsal and ventral views, respectively. 
Republic (Ždárková 1967); Poland (Chmielewski 1975, 1977); former Yugoslavia (Chmielewski 1975); Bulgaria (Nachev and Trenchev 1987); Russia (Zachvatkin 1941); Georgia (Reck 1976); Iran (Kamali et al. 2001); Egypt (Elkawas 2011); Republic of Côte d'Ivoire (Fain 1974); Cuba (de la Torre Morin et al. 2006); Canada (Sinha 1964), USA (Hughes 1976; Philips 2009); Brazil (Mazzuco et al. 2000); the Philippines (Olsen 1983); China (C. Li et al. 2014), including Hong Kong (Olsen 1983) and Taiwan (Tseng 1989); New Zealand (Cotter et al. 2011); and Australia (Womersley 1941).

Thyreophagus entomophagus is a pest of various commodities, such as: flour (Cotter et al. 2011; Mazzuco et al. 2000; Newstead and Morris 1920; Zachvatkin 1941; Ždárková 1967); dry Spanish fly Lytta vesicatoria harvested for medicinal use (Fumouze and Robin 1867); vanilla pods and saffron for medicinal use (Moniez 1892); dried medicinal plants, including ergot and cardamom; stimulants; spices; food products and fodders (rye and wheat bran) (Chmielewski 1975); poultry meal (Newstead and Morris 1920). Ingesting infested food may produce occupational respiratory disorders and anaphylaxis (Iglesias-Souto et al. 2009; Mazzuco et al. 2000; Musken et al. 2000). This species has also been recorded as a pest in entomological collections, preferentially developing on large insects; being especially abundant on Locusta migratoria (Orthoptera) and Sesia (Lepidoptera) (Laboulbène and Robin 1862). It is common pest in southern France (Laboulbène and Robin 1862), whereas only a few specimens infesting insect collections have been found in Belgium and England (Fain 1982; Michael 1903). It has also been found in association with scale insects (Elkawas 2011; Nachev and Trenchev 1987). It can feed on larval skins and live coccids (Nachev and Trenchev 1987); on trogid beetles (Philips 2009); ergot of rye (Michael 1903); bird nests (Wasylik 1959; Woodroffe 1953); bracket fungi Fomitopsis betulina (Pielou and Verma 1968); and various materials in beehives of Apis mellifera, such as debris, bee bread, pollen, dead bee brood, and mold (Chmielewski 1977, 1991).

Remark. This mite has been reported as a pest infesting dry insect collections in France and named (without a formal description) Acarus entomophagus (Laboulbène 1852). Later, this taxon was properly described based on adults and nymphs (Laboulbène and Robin 1862). Although in the latter work, the authorship of "Acarus entomophagus" (nomen nudum) is attributed to Laboulbène, the use of the phrase "Tyroglyphus entomophagus nobis" (Tyroglyphus entomophagus new), without explicitly attributing it to Laboulbène (p. 321), indicates that this species should have a joint authourship of Laboulbène and Robin. Therefore, the authour and year of this species should be reported as Thyreophagus entomophagus (Laboulbène and Robin, 1862), not "(Laboulbène, 1852)", as often cited in the literature (De Camargo Barbosa et al. 2016; Fain 1982; Fain et al. 2000).

Material examined. $1 \mathrm{HDNs}$, Russia, Tyumen Region, Tyumen District, vicinity of settlement Uspenka, $57^{\circ} 04^{\prime} \mathrm{N}, 65^{\circ} 04^{\prime} \mathrm{E}$, alcohol sediments from pheromone traps for Ips typographus, 22 May 2017, coll. A.A. Khaustov; 1 HDN, same data, 28 May 2017.

\section{Thyreophagus aff. odyneri}

(Figs. 26A, B)

Our specimen is similar to Thyreophagus odyneri Fain, 1982 but differs by: robust apical, ventral, tarsal setae III $\left(s, u^{\prime}, u^{\prime \prime}, v^{\prime}, v^{\prime \prime}\right)$, being approximately $1 / 3$ of the condylophore length (shorter than 1/3 of the condylophores in Th. odyneri); absence of tibial setae $h T$ I-II (present as a minute spine in Th. odyneri); presence of tarsal setae $w$ III alveolus (absent in Th. odyneri). The latter two character states are also similar to those of Thyreophagus cooremani Fain, 1982 but T. cooremani is much smaller and the anterior part of the spermatheca is not vase-shaped as in Th. aff. odyneri and Th. odyneri.

Material examined. 1 female, Russia, Tyumen Region, Tyumen District, vicinity of settlement Uspenka, $57^{\circ} 04^{\prime} \mathrm{N}, 65^{\circ} 04^{\prime} \mathrm{E}$, alcohol sediments from pheromone traps for Ips typographus, 5 June 2017, coll. A.A. Khaustov.

\section{Tyrophagus putrescentiae (Schrank, 1781)}

This species is cosmopolitan; its range includes Antarctica. It occurs on a wide variety of commodities and hosts, and is common in stored food, house dust, as well as peridomestic and agricultural habitats. Feeds on various organic materials, fungi, and nematodes. It is a pest of stored food, agricultural produce, as well as microbiological, plant, and insect cultures (Klimov et al. 2016). It causes allergies in humans and domestic animals (Arlian et al. 1984; Erban et al. 2016). Phoretic deutonymphs are not formed, and dispersal is accomplished by the feeding stages' active movement, air currents, or host movement (Klimov et al. 2016). Mites can spread dangerous 


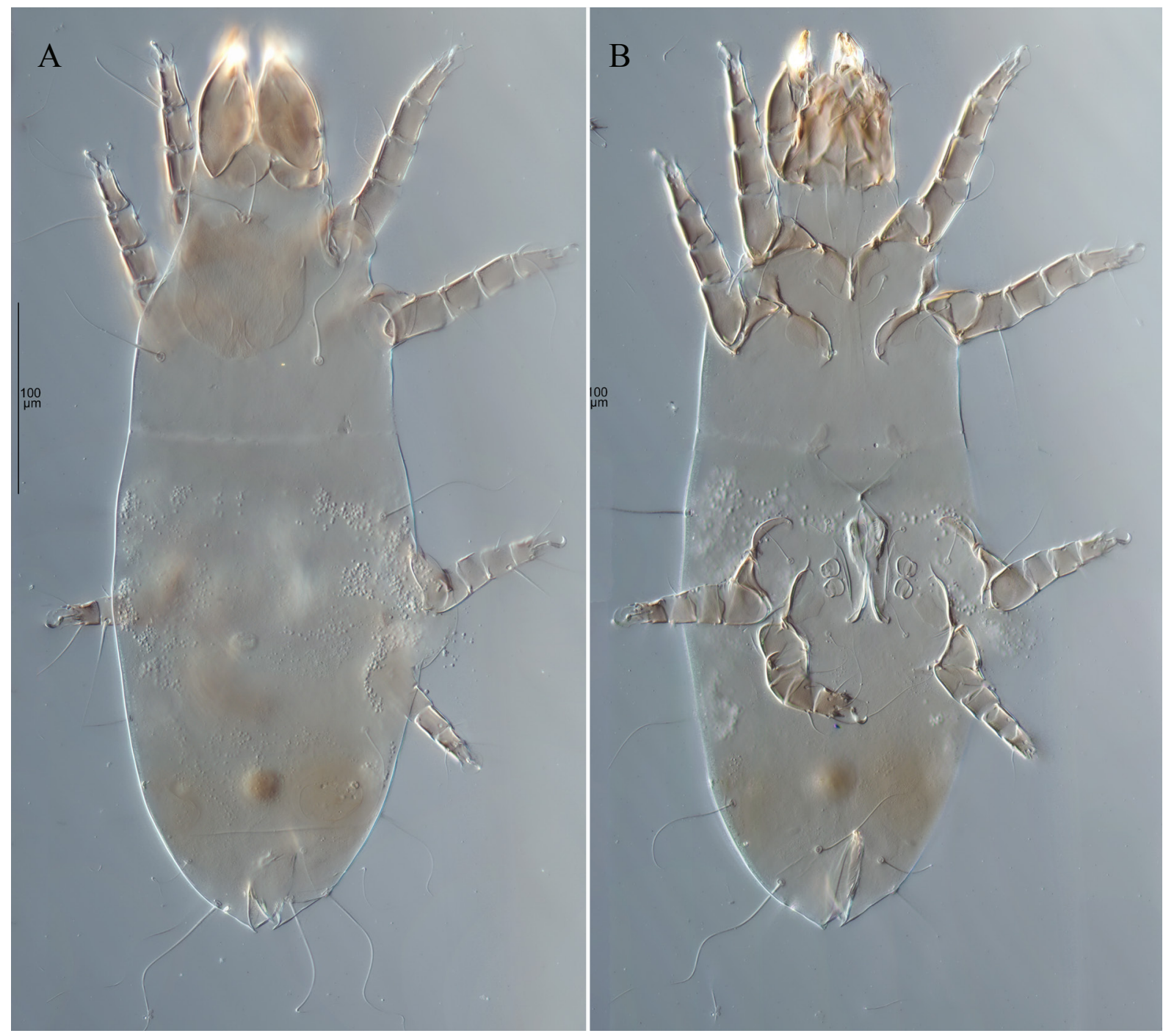

Fig. 26. A, B-Thyreophagus aff. odyneri, female, dorsal and ventral views, respectively.

fungi (e.g., those that develop on grain) by carrying fungal spores on their bodies, in the digestive system, or in feces (Griffiths et al. 1959). Experiments have shown that Tyrophagus putrescentiae is able to spread genetic variants of the fungus Ophiostoma ulmi, one of the causative agents of the Dutch elm disease. Crosses of pathogenic and non-pathogenic strains of this fungus resulted in partial reproductive incompatibility (Brasier 1978).

Mite associations with bark beetles include the following species: Dendroctonus frontalis, Gnathotrichus materiarius, Ips avulsus, Ips calligraphus, Ips grandicollis, Ips pini, Trypodendron scabricollis in the USA (Moser 1975; Moser and Roton 1971; Pfammatter et al. 2013). T. putrescentiae can be found in beetles' galleries as well as on adult beetles.
Material examined. 3 females, 3 males, Russia, Tomsk Region, nr. Tomsk, galleries of Polygraphus proximus, lab culture 6 May 2017; 1 male, Russia, Tyumen Region, Tyumen District, vicinity of settlement Uspenka, $57^{\circ} 04^{\prime} \mathrm{N}, 65^{\circ} 04^{\prime} \mathrm{E}$, alcohol sediments from pheromone traps for Ips typographus, 15 June 2017, coll. A.A. Khaustov.

\section{Family Hemisarcoptidae \\ Divilia aff. occidentalis}

(Figs. 27 A, B)

Mites of the genus Divilia are primarily associated with subcortical and wood-visiting Coleoptera and Hymenoptera, but this genus is also known from tabanid (Mullen et al. 1989), syrphid (OConnor 1989), and asilid flies (OConnor 1991). The genus is distributed in the Holarctic, with three described Palaearctic species (see below) and at 


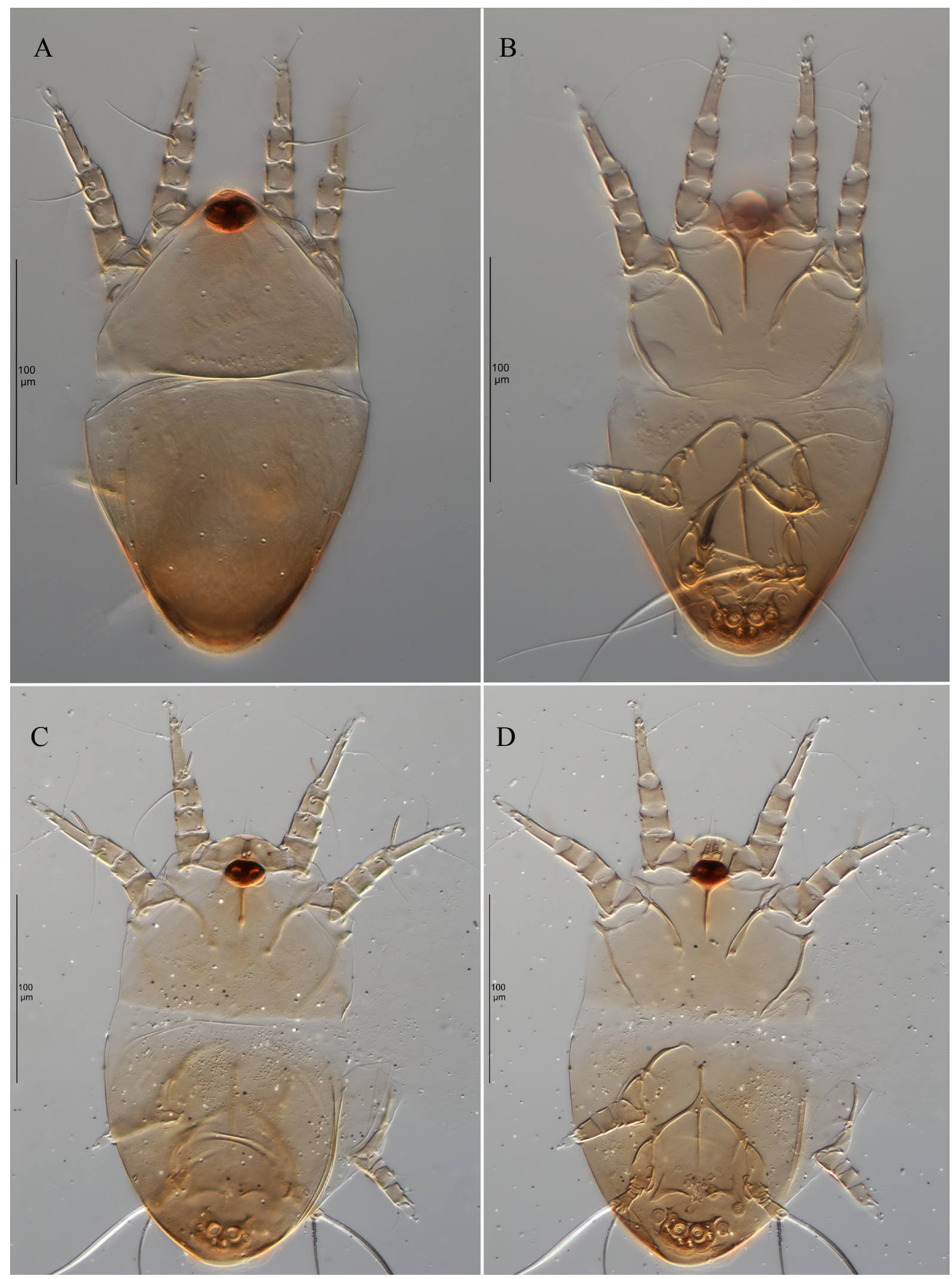

Fig. 27. Divilia aff. occidentalis, phoretic deutonymph, dorsal and ventral views, respectively, C, D—Divilia sp. (smooth dorsum, 5 setae on tarsus IV, no sigma II), phoretic deutonymph, dorsal and ventral views, respectively. 
least five undescribed species in North America (Mullen et al. 1989; OConnor 1991):

Divilia oculata Sevastianov, 1969. Known from phoretic deutonymphs, on Lasius fuliginosus in Ukraine and Formica rufa and Formica polyctena (Formicidae) in Russia (Sevastianov 1969).

Divilia occidentalis Fain, Hurst, Tweddle, Lachlan, Majerus and Britt, 1995. Known from phoretic deutonymphs on ladybugs Chilocorus renipustulatus in England (Fain et al. 1995).

Divilia exigua Fain, Hurst, Fassotte, Webberley, Sloggett, Majerus, 1997. Known from phoretic deutonymphs found on ladybugs Vibidia duodecimguttata in Poland (Fain et al. 1997).

Our specimens differ from other described species by the following character states: dorsal striation is present, at least on the posterior hysterosoma (absent in D. exigua, present in D. oculata and $D$. occidentalis); palps are elongated (same in D. occidentalis and D. oculata, short in D. exigua); anterior coxal apodemes III extend at an angle to meet the median sclerite (same in $D$. occidentalis and D. exigua, almost transverse in D. oculata); alveoli $l a$ and $3 a$ are not visible (same in D. oculata and D. occidentalis, visible in D. exigua); solenidion $\sigma$ II is absent (same in D. oculata and $D$. occidentalis; present in D. exigua); setae $c G$ II are situated at the base of genu II (same in $D$. occidentalis; nearly at the middle of the segment in D. exigua; unknown in D. oculata); tarsus IV with 5 setae -3 short and 2 long (D. occidentalis and D. exigua have 4 setae: 2 short and 2 long-although, it is possible that the other short seta has not been observed; $D$. oculata was depicted with a single short seta).

Remark. Our specimens show variable striation pattern of the dorsum, ranging from both prodorsum and hysterosoma being completely striated to only the posterior hysterosoma being striated. Thus, given that the number of short setae in tarsus IV may not have been accurately detected in the original description of D. occidentalis (coupled with the fact that the pattern of dorsal striation is variable), our species can be identified as D. occidentalis. However, before our specimens can be confidently assigned to $D$. occidentalis, the type material of $D$. occidentalis needs to be re-examined and an extensive study of the natural variation in the striation pattern needs to be done.

Material examined. $1 \mathrm{HDN}$, Russia, Tyumen Region, Tyumen District, vicinity of settlement Uspenka, $57^{\circ} 04^{\prime} \mathrm{N}, 65^{\circ} 04^{\prime} \mathrm{E}$, alcohol sediments from pheromone traps for Ips typographus, 22 May
2017, coll. A.A. Khaustov; 3 HDNs, same data, 5 June 2017.

\section{Divilia sp. [smooth dorsum, 5 setae on tarsus IV, no sigma II]}

(Figs. 27C, D)

Our specimens have a completely smooth dorsal idiosoma (no striation pattern) and short palps, which is similar to D. exigua. Our specimens, however, differ by: the presence of 5 setae on tarsus IV (vs. 4 setae in D. exigua); alveoli $1 a$ and $3 a$ either not being visible or only alveolus $3 a$ being visible ( $1 a$ and $3 a$ are distinct in D. exigua); solenidion $\sigma$ II being absent (present in D. exigua); setae $c G$ II being situated at the base of genu II (in D. exigua they are nearly in the middle of the segment).

Material examined. 2 HDNs, Russia, Tyumen Region, Tyumen District, vicinity of settlement Uspenka, $57^{\circ} 04^{\prime} \mathrm{N}, 65^{\circ} 04^{\prime} \mathrm{E}$, alcohol sediments from pheromone traps for Ips typographus, 5 June 2017, coll. A.A. Khaustov.

\section{Hemisarcoptes sp.}

(Figs. 28A, B)

Species of Hemisarcoptes are predators of armored scale insects (Diaspididae): they feed on the insects themselves or on their eggs. All nondeutonymphal stages occur under the scale cap, with their chelicerae imbedded into the host tissues. Mites display no preference for a particular host species. Mite attacks result either in a decreased or no egg production of the insect host (1-10 mites attacking together), or death (if more than 10 mites attack) (Gerson and Schneider 1981). Deutonymphs disperse on coccinellid beetles of genus Chilocorus, which are also predators of scale insects. The mites attach to the beetle elytron, in the subelytral surface during transport (Houck 1999). Attached mites can extract coleopteran host haemolymph by perforating the hypodermis of the elytron with the help of negative pressure exerted by their powerful caudoventral suckers (Houck and Cohen 1995). The beetle hemolymph contains toxic alkaloids, which appear not to affect the mites (Houck 1994). The genus Hemisarcoptes is distributed worldwide (Houck 1999), but it has not been recorded in Russia previously. While the genus can be identified by the elongated ambulacra in nondeutonymphal stages, the identification to species in our case is not possible because we had only discovered a single larva. Here, we list known 
European species along with their type hosts and localities (Dzibladze 1969; Fain and Ripka 1998; Lignières 1893):

Hemisarcoptes coccisugus Lignières, 1893. On the apple mussel scale Lepidosaphes ulmi (Diaspididae) on apple branches in France; André (1942) considered it as a junior synonym of Hemisarcoptes malus (Shimer, 1868) from Lepidosaphes conchiformis (Diaspididae) on apple trees in Ohio, USA, but see Fain and Ripka (1998)

Hemisarcoptes budensis Fain and Ripka, 1989. On Unaspis euonymi (Diaspididae) on the Oriental bittersweet Celastrus orbiculatus, holotype phoretic deutonymph was collected from Chilocorus renipustulatus (Coccinellidae) in the same locality in Hungary; other five host species of armored scale insects, attacking 12 species of ornamental trees were listed.

Hemisarcoptes dzhashii Dzibladze, 1969. On Lepidosaphes beckii (type host), Lepidosaphes gloverii, Aonidiliella citrina, Chrysomphalus dictyospermi (Diaspididae) on Citrus reticulata in Georgia (Dzibladze 1969).

Material examined. 1 larva, Russia, Tyumen Region, Tyumen District, vicinity of settlement Uspenka, $57^{\circ} 04^{\prime} \mathrm{N}, 65^{\circ} 04^{\prime} \mathrm{E}$, alcohol sediments from pheromone traps for Ips typographus, 28 May 2017, coll. A.A. Khaustov.

\section{Nanacarus sp.1 (prodorsum striated, $c_{1}$ widely separated)}

(Figs. 29A, B)

Species of the genus Nanacarus inhabit bark, subcortical spaces, woody bracket fungi, and the burrows of wood-boring insects. These species show little or no specificity in phoretic hosts (OConnor 1982). One species, Nanacarus minutus, is known to occur in bird, soil, stored food products, and house dust (see below). The genus Nanacarus inhabits the Old World and North America (Halliday 2000; Oudemans 1901; Pielou and Verma 1968). Several species were described (see below) but a careful revision is necessary to identify them. Numerous undescribed species have also been reported (Halliday 2000; Hofstetter 2011; Hofstetter et al. 2013; Kurosa 2000; Matthewman and Pielon 1971; Mercado et al. 2014; OConnor 1991; Penttinen et al. 2013; Pielou and Verma 1968). Among them, multiple, apparently sympatric morphospecies are known: three in Japan (Kurosa 2000) and five in Michigan, USA (OConnor 1991).
Bark beetle hosts include (all mite species are undescribed/unidentified): Ips typographus in Finland (Penttinen et al. 2013) and Germany (Moser and Bogenschütz 1984); Pityokteines curvidens in Switzerland (Pernek et al. 2012); Dendroctonus frontalis in Arizona, USA (Hofstetter 2011; Hofstetter et al. 2013); Dendroctonus ponderosae in North America (Mercado et al. 2014).

\section{Species of Nanacarus}

Nanacarus astoma (E. Türk and F. Türk, 1957) $[=$ Calvolia astoma E. Türk and F. Türk, 1957]. Only phoretic deutonymphs are known from Formica rufa and Lasius fuliginosus (Formicidae) in Germany (Türk and Türk 1957), Formica polyctena, Myrmica laevinodis, Myrmica ruginodis, Lasius fuliginosus in Poland (Kiełczewski and Wiśniewski 1971).

Nanacarus collembolicola (Fain and Johnston, 1974) [=Congovidiella collembolicola Fain and Johnston, 1974]. Known from phoretic deutonymphs, on the springtail Allacma fusca (Sminthuridae) in England (Fain and Johnston 1974). SEM images of Nanacarus sp. from Ips typographus in Finland (Penttinen et al. 2013) resemble this species.

Nanacarus hieroglypha (Fain and Elsen, 1971). Known from phoretic deutonymphs from tsetse flies Glossina fuscipes fuscipes and Glossina fuscipes quanzensis from the Democratic Republic of the Congo.

Nanacarus hungaricus Halmai and Mahunka, 1980. Adults, HDNs. Oryctolagus cuniculus cage in Hungary. Fain (1988) stated that HDNs are similar to Nanacarus minutus.

Nanacarus minutus (Oudemans, 1901). Non-deutonymphal stages were collected from mammals Eptesicus serotinus (type host), Pipistrellus pipistrellus, Sorex araneus from Germany, bird Megapodius reinwardt buruensis (Megapodiidae) from Buru Island, Indonesia (Oudemans 1928), bee Xylocopa (Koptorthosoma) tenuiscapa from Java, Indonesia (Oudemans 1901, 1903), wheat in Belgium (Fain 1988), nest of a wild pigeon (with phoretic deutonymphs) in Belgium (Fain 1988), in the former Czechoslovakia (Černý and Samšiňák 1971), flour in Russia (Zachvatkin 1941), house dust in Japan (Oshima 1977), stored food in China (L.-S. Li et al. 1992) and from soil in Saudi Arabia (Bayoumi and Al-Khalifa 1983). Phoretic deutonymphs HDNs are known but undescribed: on the longhorn beetle Leiopus nebulosus, unidentified insects (Fain 1988), a coccinelid Adalia 

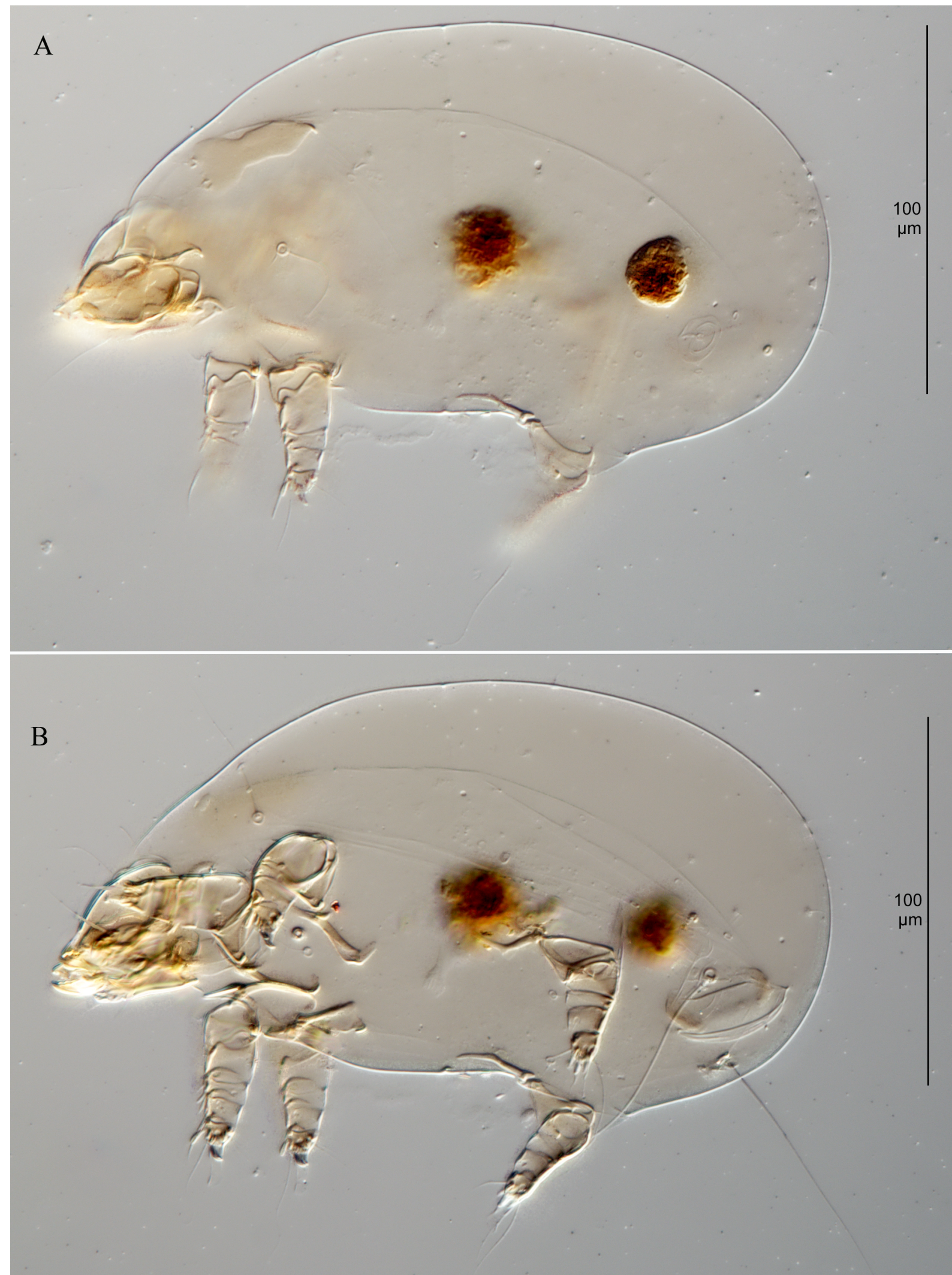

Fig. 28. A, B-Hemisarcoptes sp., larva, dorsal and ventral views, respectively.

sp. in Belgium (Fain et al. 1997), Vibidia duodecimguttata and Exochomus quadripustulatus (Coccinellidae) in Poland (Fain et al. 1997). Oudemans (1939) synonymized this species with
Acarus caudatus Canestrini and Fanzago, 1877 from Italy (nom. preocc. De Geer, 1778), but we do not support this synonymy because "Acarus caudatus" has claws and long legs. 


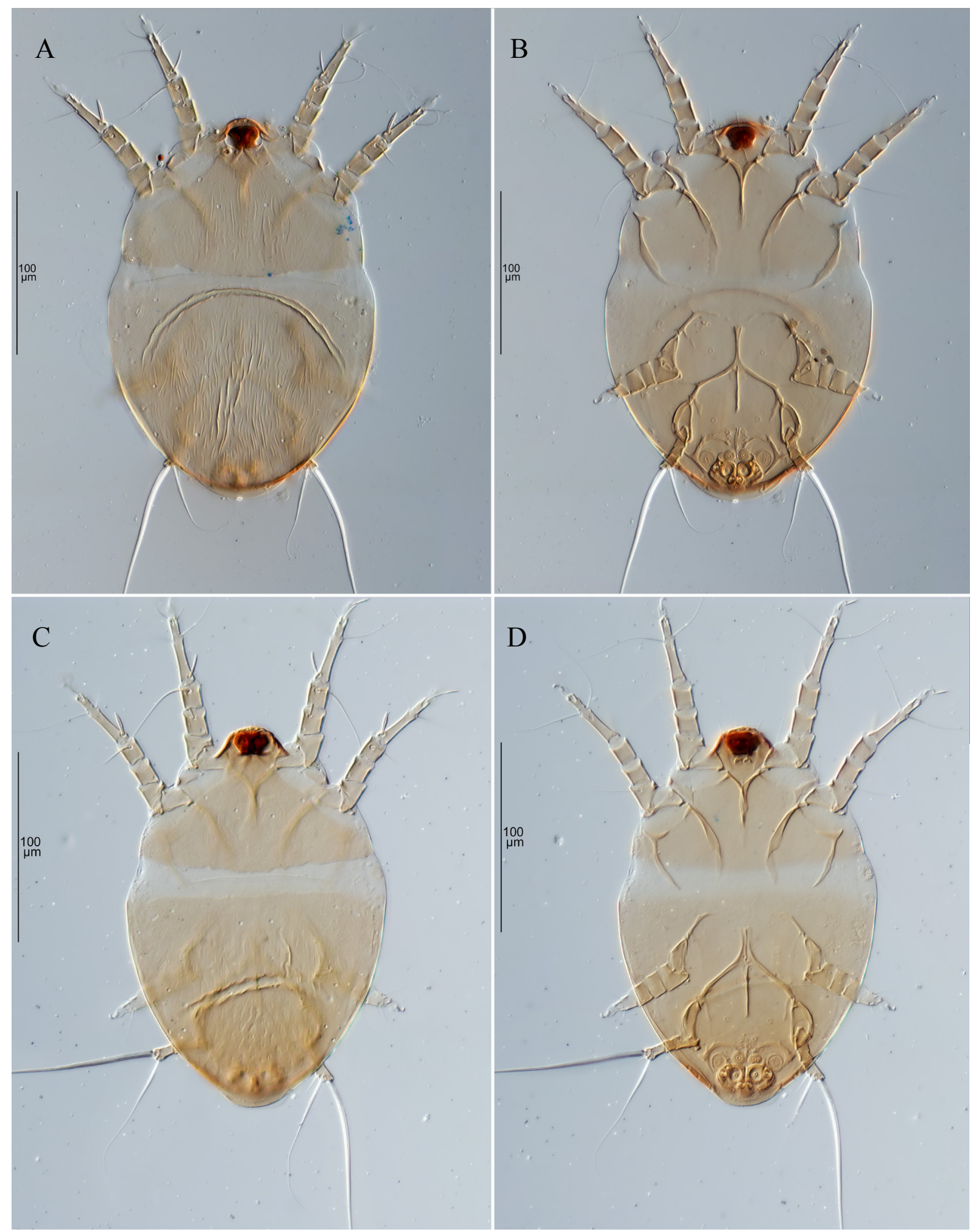

Fig. 29. A, B-Nanacarus sp.1 (prodorsum striated, $c_{1}$ widely separated), phoretic deutonymph, dorsal and ventral views, respectively, C, D-Nanacarus sp.2 (prodorsum smooth or nearly smooth, $c_{1}$ closely separated), phoretic deutonymph, dorsal and ventral views, respectively.

Nanacarus pragensis (Samšiňák, 1983). Czech Republic. Known from a single phoretic deutonymph, collected from soil under trees, where people feed pigeons (Samšiňák and Vobrázková 1983).
Note: 'Nanacarus' nominis Woodring, 1966 belongs to Suidasiisae: Sapracarinae.

Our specimen has striated prodorsum, intercalary sclerites between anterior apodemes III and 
the ventrum; setae $c_{1}$ widely separated; and a short, almost conical, tarsus III. These character states, except for the widely separated $c_{l}$, are similar to those of Nanacarus collembolicola ( $c_{1}$ not widely separated). In the descriptions of Nanacarus pragensis and $N$. hungaricus, tarsi III are shown somewhat elongated and not conical, and intercalary sclerites are lacking.

Material examined. 2 HDNs, Russia, Tyumen Region, Tyumen District, vicinity of settlement Uspenka, $57^{\circ} 04^{\prime} \mathrm{N}, 65^{\circ} 04^{\prime} \mathrm{E}$, alcohol sediments from pheromone traps for Ips typographus, 22 May 2017, coll. A.A. Khaustov; 1 HDN, same data, June 2017.

\section{Nanacarus sp.2 [prodorsum smooth or nearly smooth, $c_{1}$ closely separated]}

(Figs. 29C, D)

The prodorsum is nearly smooth; setae $c_{l}$ are closely separated; intercalary sclerites between apodemes III and ventrum are absent, tarsus III is short, almost conical.

Material examined. 2 HDNs, Russia, Tyumen Region, Tyumen District, vicinity of settlement Uspenka, $57^{\circ} 04^{\prime} \mathrm{N}, 65^{\circ} 04^{\prime} \mathrm{E}$, alcohol sediments from pheromone traps for Ips typographus, 28 May 2017, coll. A.A. Khaustov; 2 HDNs, same data, 5 June 2017; 1 HDN, 15 June 2017; 1 HDN, June 2017.

\section{Superioropus huronmontanus OConnor and Houck, 1989}

(Figs. 30A, B)

This species is known from phoretic deutonymphs collected from Exeristes comstockii (Ichneumonidae) in Michigan, USA (OConnor 1991; OConnor and Houck 1989). Comparison of our specimens did not reveal any substantial differences with the original description. This is the first record of this genus and species for the Palaearctic region.

Material examined. $5 \mathrm{HDNs}$, Russia, Tyumen Region, Tyumen District, vicinity of settlement Uspenka, $57^{\circ} 04^{\prime} \mathrm{N}, 65^{\circ} 04^{\prime} \mathrm{E}$, alcohol sediments from pheromone traps for Ips typographus, 5 June 2017, coll. A.A. Khaustov; 4 HNDs, same data, 15 June 2017; 3 HDNs, same data, June 2017.

Family Winterschmidtiidae Oudemans, 1923

\section{Parawinterschmidtia kneissli (Krausse, 1919)}

(Figs. 30C, D)

This is a European species known based on descriptions of both phoretic deutonymphs and adults (Khaustov 2000a; Türk and Türk 1957). Feeding stages are mycophagous in bark beetle galleries. Phoretic hosts include a broad array of subcortical and wood-visiting arthropods, such as bark beetles and their predators (e.g., the ant beetle Thanasimus formicarius). Bark beetle hosts are: Orthotomicus laricis (Krause 1917 (1919)) (type host); Tomicus piniperda (Khaustov 2000a), Hylastes attenuatus (Ermilov et al. 2007). Non-bark beetle hosts: Brachyderes incanus (Türk and Türk 1957), Hylobius abietis (Ermilov et al. 2008; Türk and Türk 1957), Pissodes pini (Ermilov et al. 2008), Pissodes piniphilus (Türk and Türk 1957) (Curculionidae); Acanthocinus aedilis (Türk and Türk 1957); Mesosa nebulosa (Samšiňák 1957); Plagionotus detritus, Monochamus galloprovincialis, Spondylis buprestoides, Rhagium sycophanta (Ermilov and Mokrousov 2008); Rhagium inquisitor (Khaustov 2000a) (Cerambycidae); Sericus brunneus (Elateridae) (Ermilov et al. 2006); Thanasimus formicarius (Cleridae) (Khaustov 2000a; Türk and Türk 1957); Crypticus quisquilius (Tenebrionidae) (Türk and Türk 1957); Myzia oblongoguttata (Coccinellidae) (Türk and Türk 1957); Raphidia sp. (larva) (Raphidioptera: Raphidiidae); Crossocerus vagabundus (common), Crossocerus leucostoma, Ectemnius cavifrons, Ectemnius cephalotes (Crabronidae), Sceliphron deforme (Sphecidae), Astata kashmirensis (Astatinae) (Ermilov and Mokrousov 2010); and a centipede Lithobius forficatus (Lithobiomorpha: Lithobiidae) (Türk and Türk 1957). This species has been recorded from the following countries: Germany (Krause 1917 (1919); Türk and Türk 1957), Belgium (Cooreman 1963), former Czechoslovakia (Černý and Samšiňák 1971), Poland (Kiełczewski and Wiśniewski 1980), and Russia (Ermilov et al. 2007; Khaustov 2000a).

Material examined. $4 \mathrm{HDNs}$, Russia, Tyumen Region, Tyumen District, vicinity of settlement Uspenka, $57^{\circ} 04^{\prime} \mathrm{N}, 65^{\circ} 04^{\prime} \mathrm{E}$, alcohol sediments from pheromone traps for Ips typographus, 22 May 2017, coll. A.A. Khaustov; 2 HDNs, 5 June 2017, same data; 1 HDN, June 2017, same data.

\section{Saproglyphus aff. hagensis [striate]}

(Figs. 31A, B)

Here, we treat the genus Calvolia Oudemans, 1911 (part.) as a junior synonym of Saproglyphus Berlese, 1890 (Fain and Rack 1987; Klimov et al. 2016). Saproglyphus hagensis Oudemans, 1911 is 


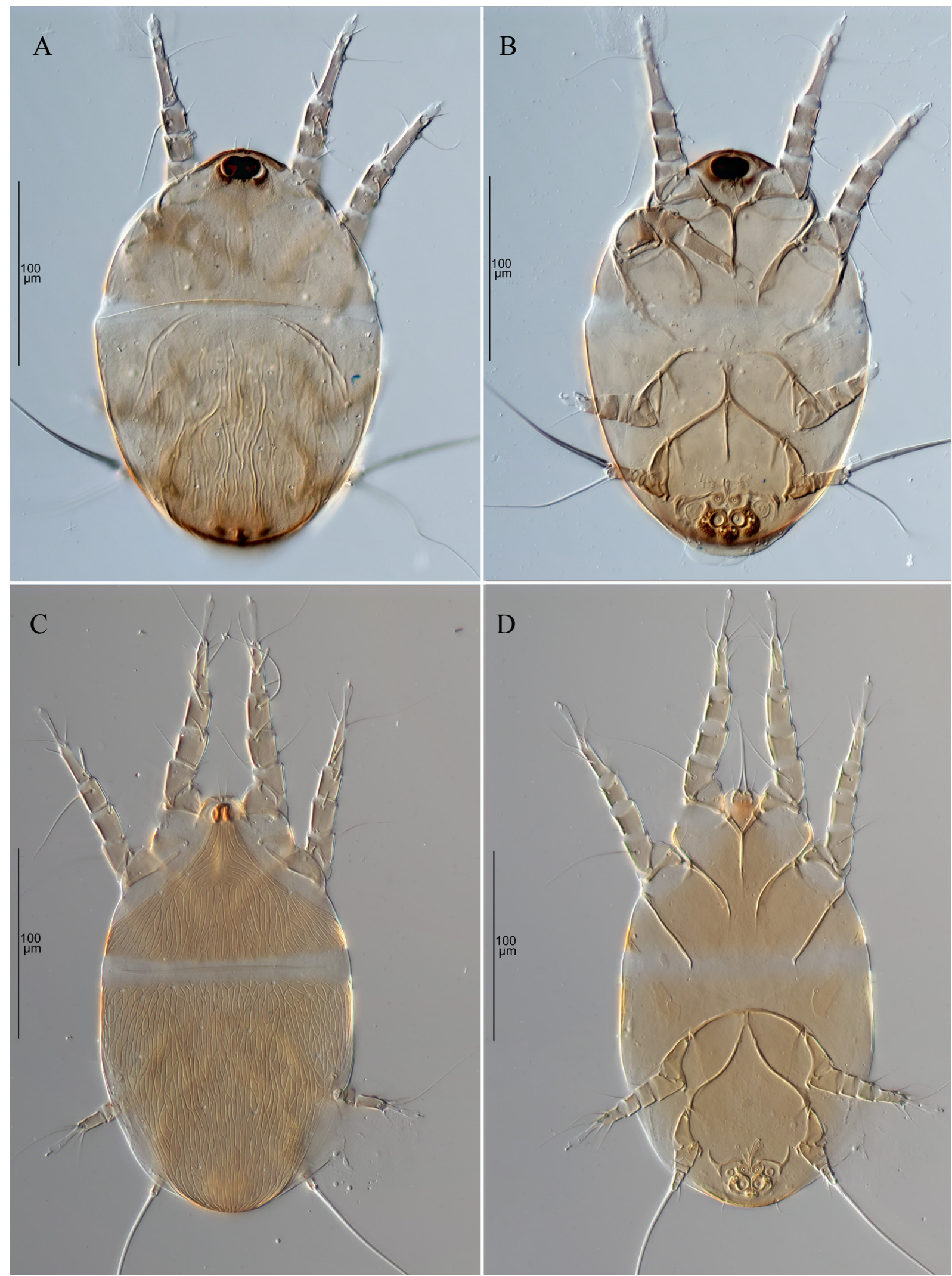

Fig. 30. A, B-Superioropus huronmontanus, phoretic deutonymph, dorsal and ventral views, respectively, C, DParawinterschmidtia kneissli, phoretic deutonymph, dorsal and ventral views, respectively.

known from phoretic deutonymphs in the Netherlands (Oudemans 1919), Belgium (Fain and Rack 1987), Switzerland (Kuhlmann 1998), and Russia
(Bugrov 1997). The Hylaeus nivalis (Colletidae) bee was reported as a phoretic host (Kuhlmann 1998). Our specimen is very similar to S. hagensis, 


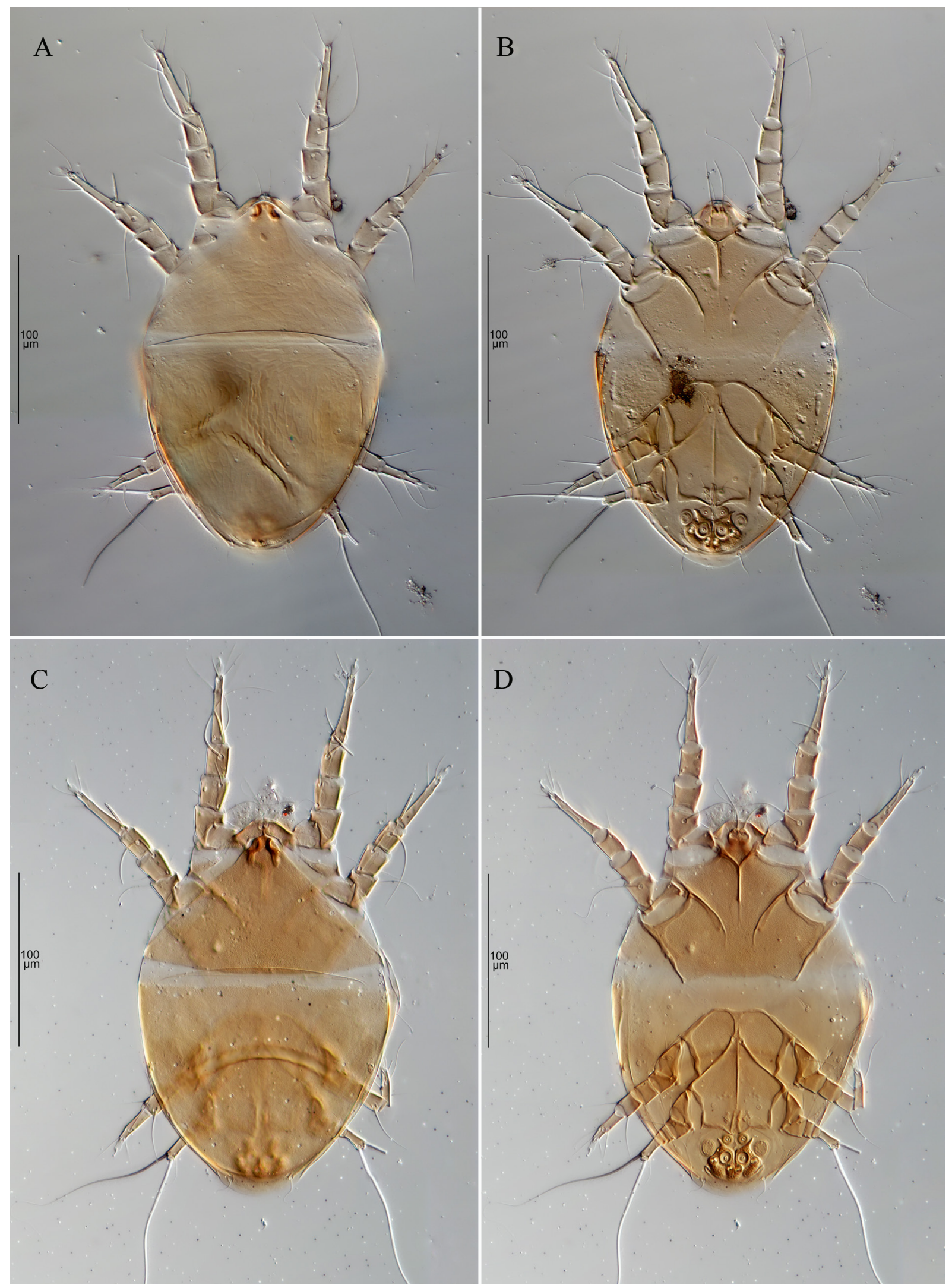

Fig. 31. A, B-Saproglyphus aff. hagensis, phoretic deutonymph, dorsal and ventral views, respectively, C, DSaproglyphus waldorfae, phoretic deutonymph, dorsal and ventral views, respectively.

which has been redescribed from the holotype that came from the Netherlands (Fain 1972), as well as based on specimens collected in Belgium (Fain and Rack 1987). It differs by the much stronger and 


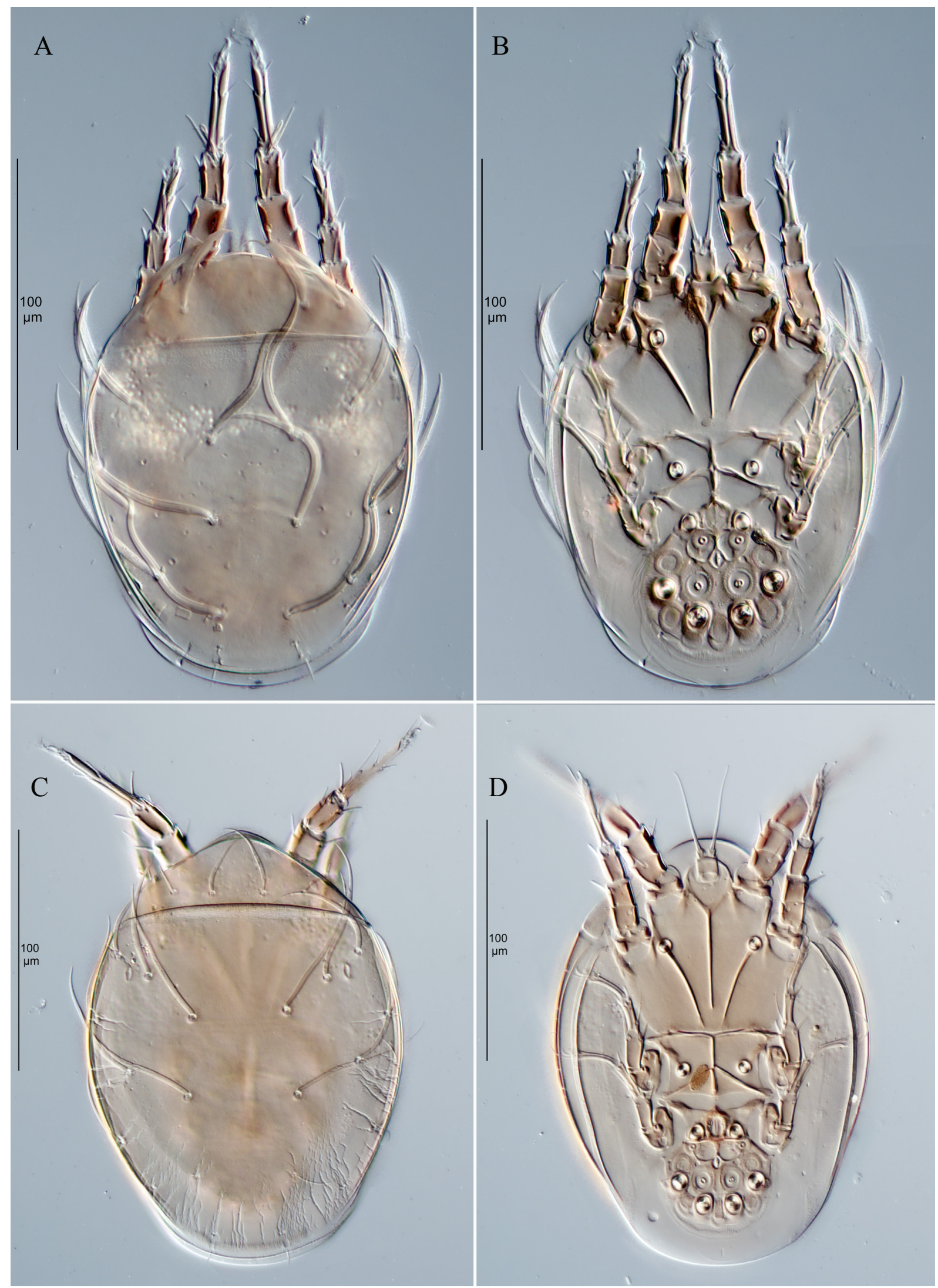

Fig. 32. A, B-Histiostoma ovalis, phoretic deutonymph, dorsal and ventral views, respectively, C, D-Histiostoma piceae, phoretic deutonymph, dorsal and ventral views, respectively.

longer tibial seta $k T \mathrm{IV}$, which clearly extends beyond tarsus IV (in S. hagensis, it does not extend- ing or nearly reaches the tip of tarsus IV); setae $w F$ IV are also long and extend tarsus IV (clearly not 


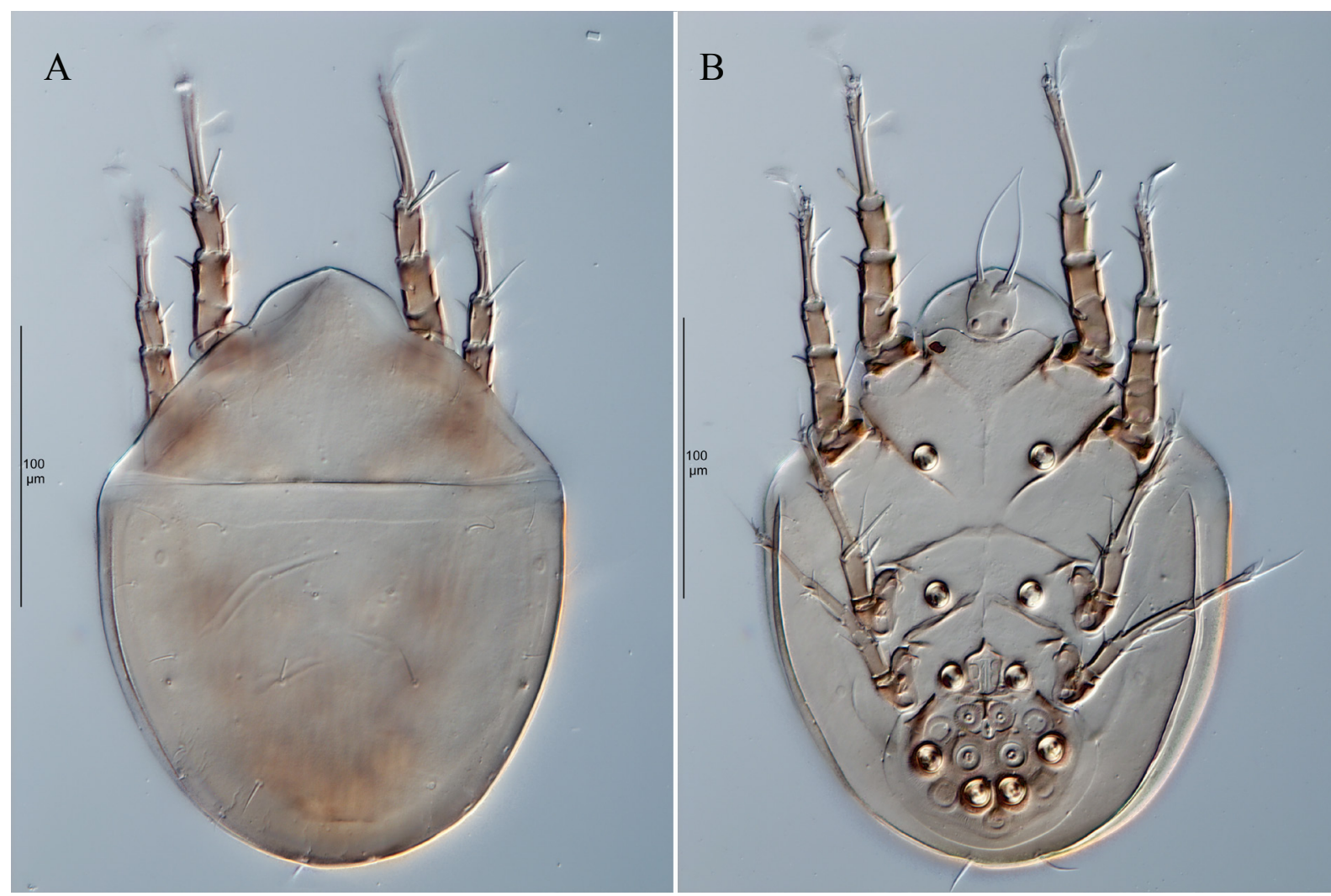

Fig. 33. A, B-Histiostoma pini, phoretic deutonymph, dorsal and ventral views, respectively.

extending in $S$. hagensis); tarsus III is distinctly longer than 3 times its width at the base (nearly 3 times as long as its base in $S$. hagensis).

Material examined. $1 \mathrm{HDN}$, Russia, Tyumen Region, Tyumen District, vicinity of settlement Uspenka, $57^{\circ} 04^{\prime} \mathrm{N}, 65^{\circ} 04^{\prime} \mathrm{E}$, alcohol sediments from pheromone traps for Ips typographus, 22 May 2017, coll. A.A. Khaustov.

\section{Saproglyphus waldorfae (Fain and Johnston, 1974)}

(Figs. 31C, D)

Our specimen resembles very closely Saproglyphus waldorfae, collected from Allacma fusca (Sminthuridae) [springtail] in England (Fain and Johnston 1974). There is a minor difference: tarsus IV is longer, as long as the short tarsal seta IV. While in the paratype of $S$. waldorfae, tarsus IV was depicted shorter than the short tarsal seta IV, in the holotype, this seta is longer than the tarsus. These discrepancies may be explained if tarsi IV of the specimens from England were oriented at an angle to the vertical plane of the slide. Other differences include: posterior sternal shield is well-separated from the anterior coxal apodemes III (vs. close to each other in S. waldorfae); setae $v i$ are separated from the eye lenses; pigmented eye spots extend posteriorly to form longitudinal sclerites (in $S$. waldorfae, setae $v i$ are adjacent to the eye lenses and longitudinal sclerites are absent/not visible). We consider these differences as artifacts of preservation because our specimen was somewhat compressed as compared to the specimen from England. This is the first record of Saproglyphus waldorfae in Russia and continental Europe.

Material examined. 1 HDN, Russia, Tyumen Region, Tyumen District, vicinity of settlement Uspenka, $57^{\circ} 04^{\prime} \mathrm{N}, 65^{\circ} 04^{\prime} \mathrm{E}$, alcohol sediments from pheromone traps for Ips typographus, 5 June 2017, coll. A.A. Khaustov.

Family Histiostomatidae Berlese, 1897

\section{Histiostoma ovalis (J. Müller, 1860)}

(Figs. 32A, B)

This species is primarily associated with Ips sexdentatus in the Western Palaearctic. It is considered an important vector of plant-pathogenic fungi (Fernández et al. 2013; Mahunka 1970; Moraza et al. 2013; Samšiňák 1958; Vissa and Hofstetter 2017). Phoretic deutonymphs of this mite species are very abundant on their bark beetle 


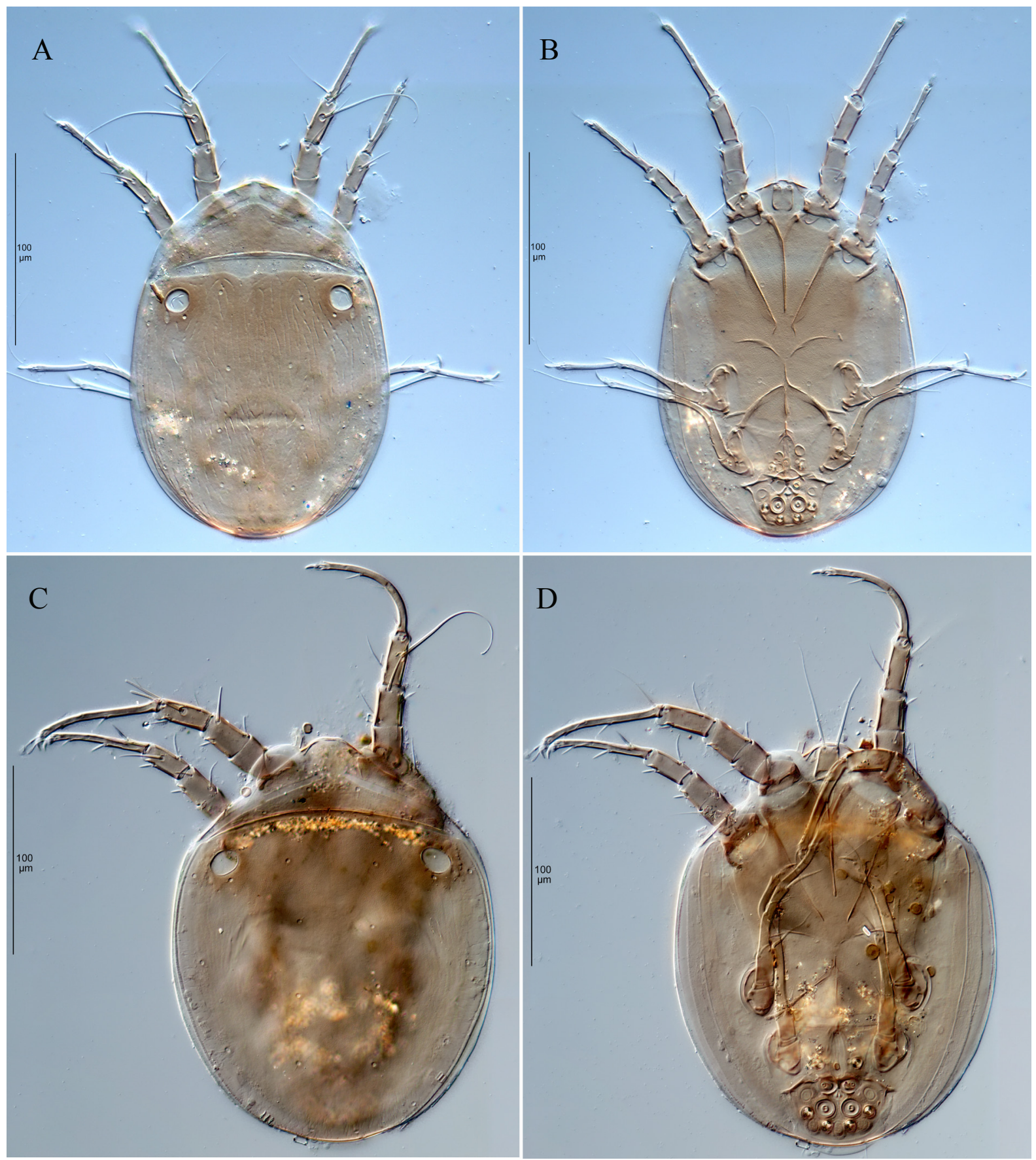

Fig. 34. A, B-Probonomoia pini, phoretic deutonymph, dorsal and ventral views, respectively, C, D-Probonomoia sibirica, phoretic deutonymph, dorsal and ventral views, respectively.

hosts and they can carry a large number of hyperphoretic fungi (Moraza et al. 2013). Multiple hyperphoretic fungal ascospores and conidia have been detected in a survey of $H$. ovalis, phoretic on Ips sexdentatus in France. Ascospores of Pichia (Saccharomycetaceae), Ophiostoma brunneociliatum, Ophiostoma minus, Ophiostoma picea, Ophiostoma section Ceratocystis, Ceratocystiopsis minuta (Ophiostomataceae); conidia of Leptographium, Sporothrix (Ophiostomataceae), Fu- sarium sp. (Nectriaceae), Ceratocystis (Ceratocystidaceae), Cladosporium sp. (Davidiellaceae), Altenaria sp. (Pleosporaceae); as well as unidentified yeast have been detected (Levieux et al. 1989). Of them, Ophiostoma minus is a pathogenic bluestain fungus of economic importance (Gorton and Webber 2000).

The mite host range is (Müller's historical records are also listed for informational purposes): Ips sexdentatus (Fernández et al. 2013; Levieux 


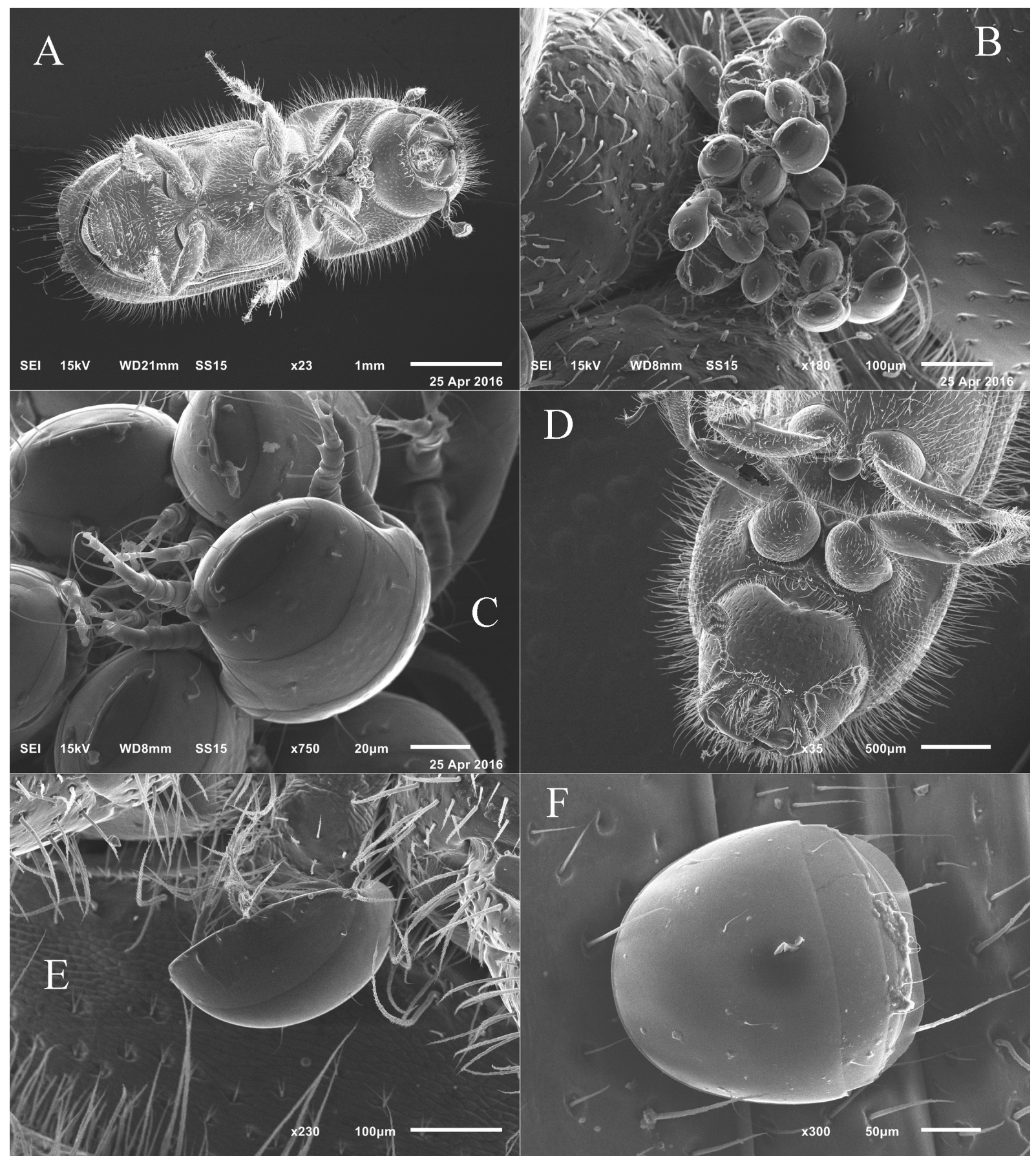

Fig. 35. SEM photographs of mites phoretic on Ips typographus. A-C-Elattoma crossi, females: A-general view, B, C-detailed view; D-F-Scutacarus scolyti, D-general view, E, F-detailed view.

et al. 1989; Mahunka 1968, 1970; Müller 1859 (1860); Samšiňák 1958; Wirth and Garonna 2015), Ips cembrae (Mahunka 1968, 1970; Scheucher 1957), Tomicus minor (Kiełczewski and Wiśniewski 1980), Orthotomicus laricis (Mülller 1859 (1860)), Pityokteines curvidens (Müller 1859 (1860)) (Curculionidae: Scolytinae), Cerylon histeroides (Cerylonidae) (Müller 1859 (1860)), Margarinotus bipustulatus (Histeridae) (Mülller 1859 (1860)), Platysoma compressum (Histeridae)
(Mahunka 1976b), and Dendrolaelaps quadrisetus (Digamasellidae) (phoretic on Ips sexdentatus) (Wirth and Garonna 2015). Histiostoma ovalis is known form the following countries: Bulgaria, Austria, Ukraine (Samšiňák 1958), France (Levieux et al. 1989; Samšiňák 1958), Belgium (Cooreman 1963), Croatia (Wirth and Garonna 2015), the Czech Republic (Müller 1859 (1860)), Germany (Scheucher 1957; Wirth and Garonna 2015), Hungary (Mahunka 1968, 1970), Italy 


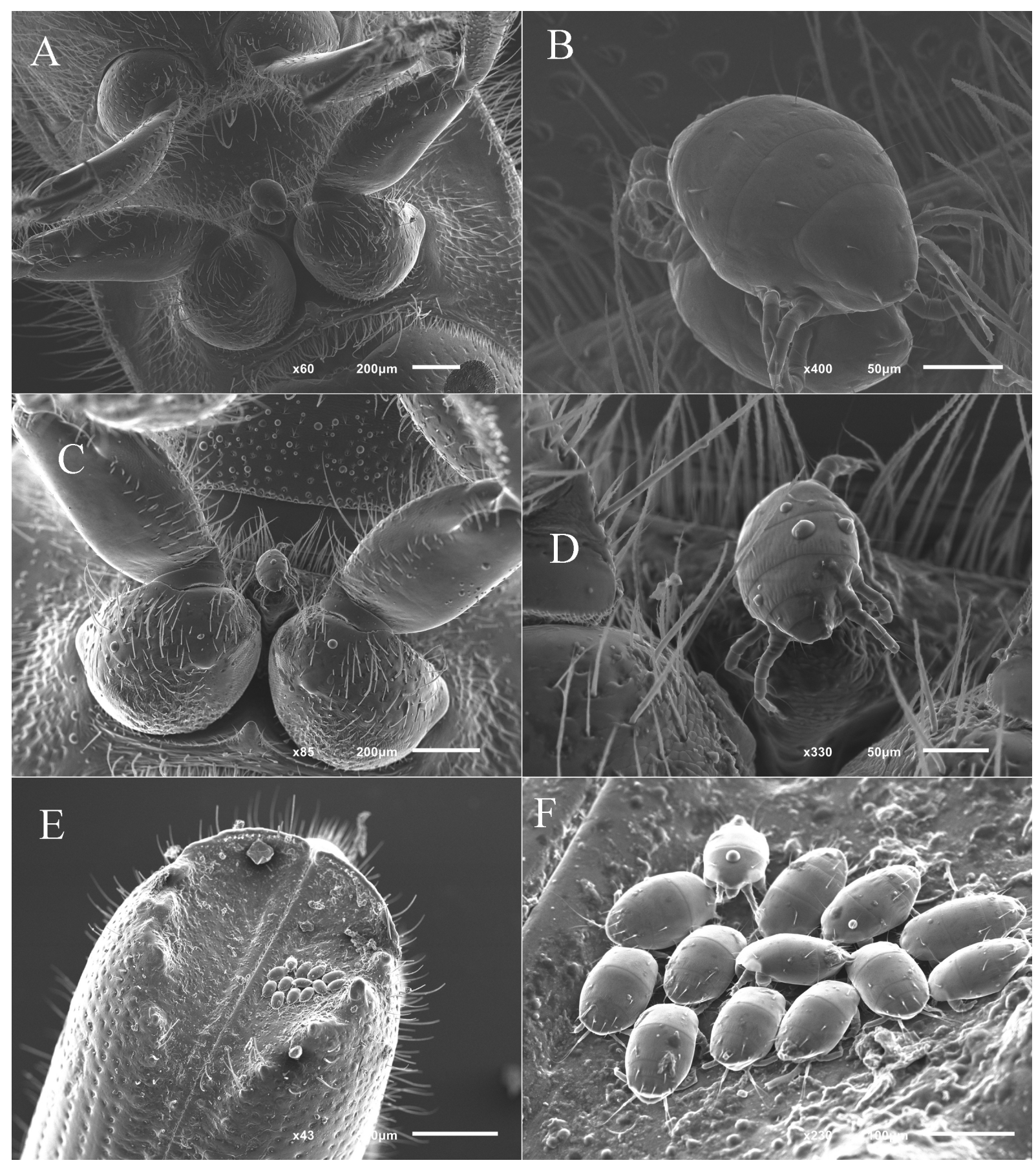

Fig. 36. SEM photographs of mites phoretic on Ips typographus. A-D - Aethiophenax ipidarius, females: A, C-general view, B, D_-detailed view; Iponemus gaebleri, females: E_-general view of elytral declivity with mites, F-detailed view of mites.

(Fernández et al. 2013; Wirth and Garonna 2015), Poland (Kiełczewski and Wiśniewski 1980), Romania (Mahunka 1970), Slovakia (type locality) (Wirth and Garonna 2015), and Russia (first record).

Remarks. This species was originally described based on a phoretic deutonymph from Ips sexdentatus and several other beetle species collected near Brno, the Czech Republic (Mülller 1859 (1860)). The type material is deemed to be lost and a neotype was designated based on a deutonymph from Ips sexdentatus from Slovakia (Wirth and Garonna 2015). It is possible that Scheucher (1957) has identified the same species collected from Ips sexdentatus and Ips cembrae in Germany under the name Histiostoma gladiger (Vitzthum, 1926). The latter species was originally described from Ips subelongatus from eastern Russia (Khabarovskiy Krai) (Vitzthum 1926). The main difference be- 


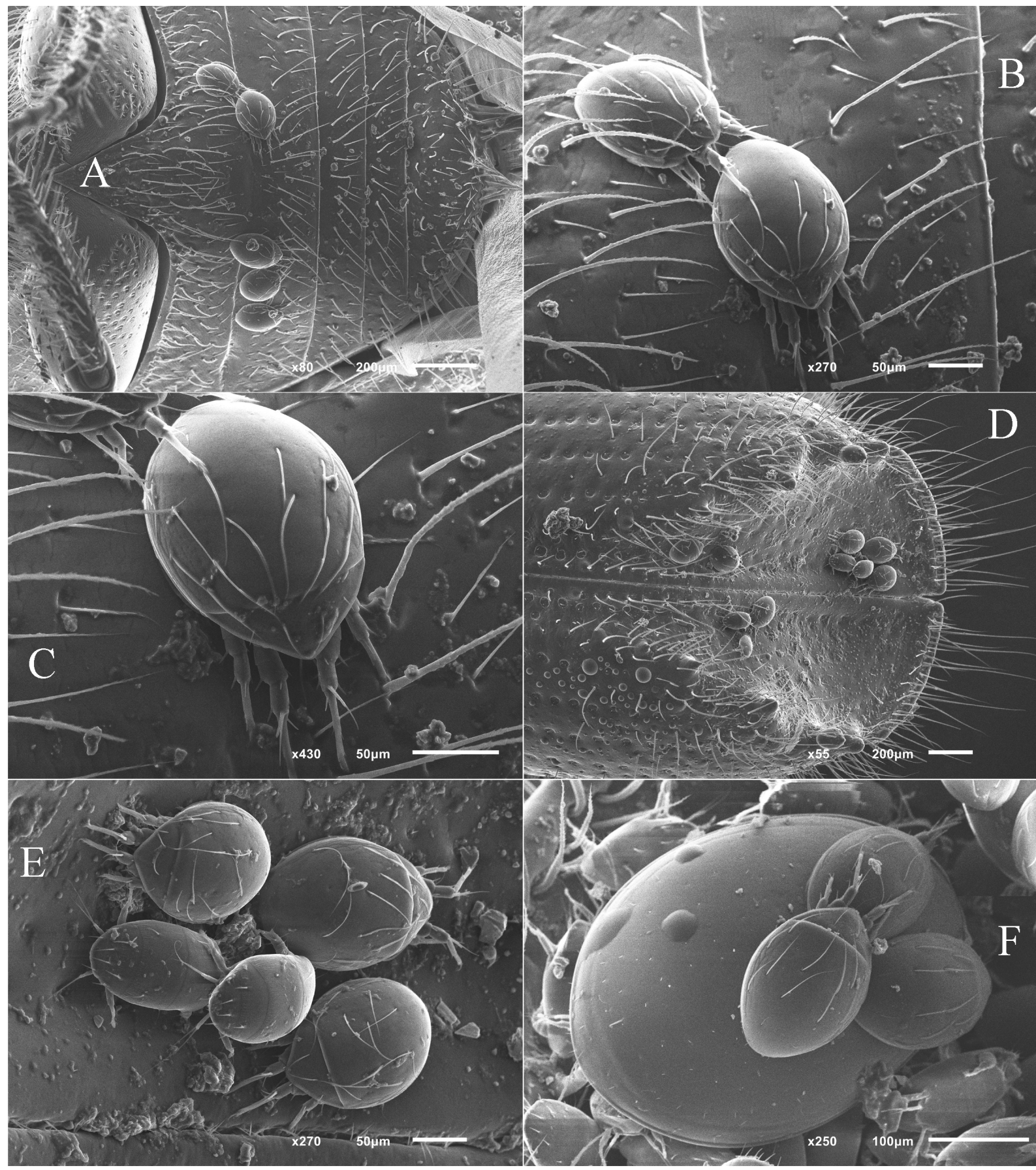

Fig. 37. SEM photographs of mites phoretic on Ips typographus. A-C-deutonymphs of Histiostoma piceae on ventral abdomen of the beetle; D, E-deutonymph of Histiostoma piceae (large mites) and females of Iponemus gaebleri (small mites) on elytral declivity of the beetle: D — general view, E-detailed view; F-deutonymph of Uroobovella ipidis with hyperphoretic deutonymphs of Histiostoma piceae.

tween Histiostoma gladiger and Histiostoma ovalis - the absence of long scapular setae in the former species - was dismissed by several authors (Cooreman 1963; Scheucher 1957) on the ground that these setae could be broken off on Vitzthum's specimen. Samšinák (1958) treated both $H$. ovalis $(=H . g l-$ adiger sensu Scheucher (1957)) and H. gladiger s.str. as two valid species. However, Cooreman
(1963) used the name $H$. gladiger for both of these putative species, while Mahunka (1970) used the name $H$. ovalis, which has priority over $H$. gladiger .

Here we provisionally treat $H$. ovalis and specimens from the Western Palaearctic identified as "H. gladiger" as the same species, whereas we provisionally consider $H$. gladiger s.str. from the Eastern Palaearctic as a separate species. 

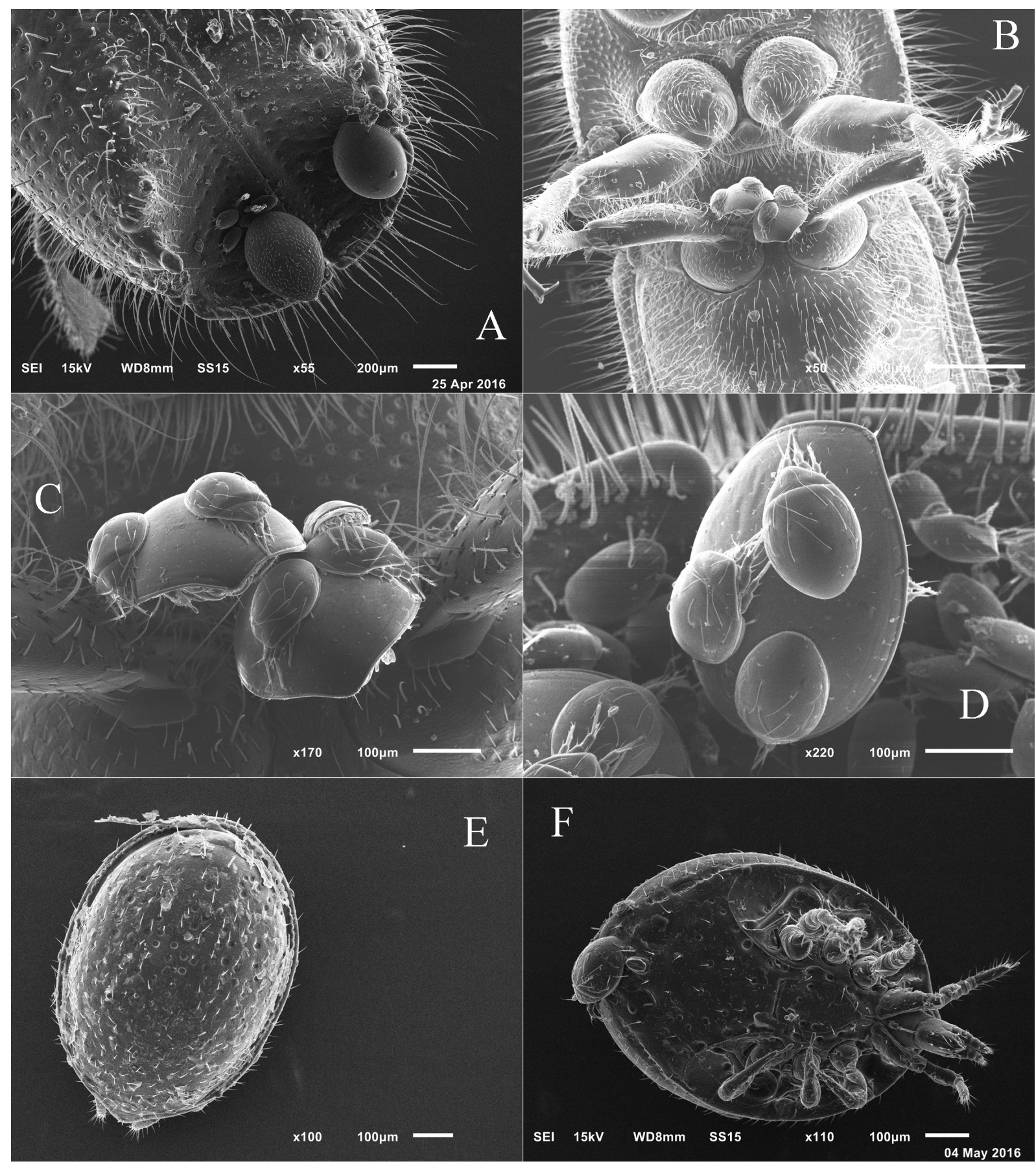

Fig. 38. SEM photographs. A-elytral declivity of the beetle with phoretic females of Iponemus gaebleri (small mites) and deutonymphs of Trichouropoda polytricha (large mite on the left) and Uroobovella ipidis (large mite on the right); B, C-deutonymphs of Uroobovella ipidis with hyperphoretic deutonymphs of Histiostoma piceae between legs II of the beetle, D - deutonymph of Uroobovella ipidis with hyperphoretic deutonymphs of Histiostoma piceae on elytral declivity of the beetle; E, F-Trichouropoda karawaiewi, female: E-dorsal view, F-ventral view with phoretic deutonymph of Histiostoma piceae.

Material examined. $1 \mathrm{HDN}$, Russia, Tyumen Region, Tyumen District, vicinity of settlement Uspenka, $57^{\circ} 04^{\prime} \mathrm{N}, 65^{\circ} 04^{\prime} \mathrm{E}$, alcohol sediments from pheromone traps for Ips typographus, 22 May 2017, coll. A.A. Khaustov; 1 HDN, 28 May 2017; 3 HDNs, 5 June 2017, same data.

\section{Histiostoma piceae Scheucher, 1957}

(Figs. 32C, D, 37A-F, 38C, D)

Histiostoma piceae is a bark beetles specialist, preferring microhabitats where fungal mycelium and spores are abundant (Hofstetter et al. 


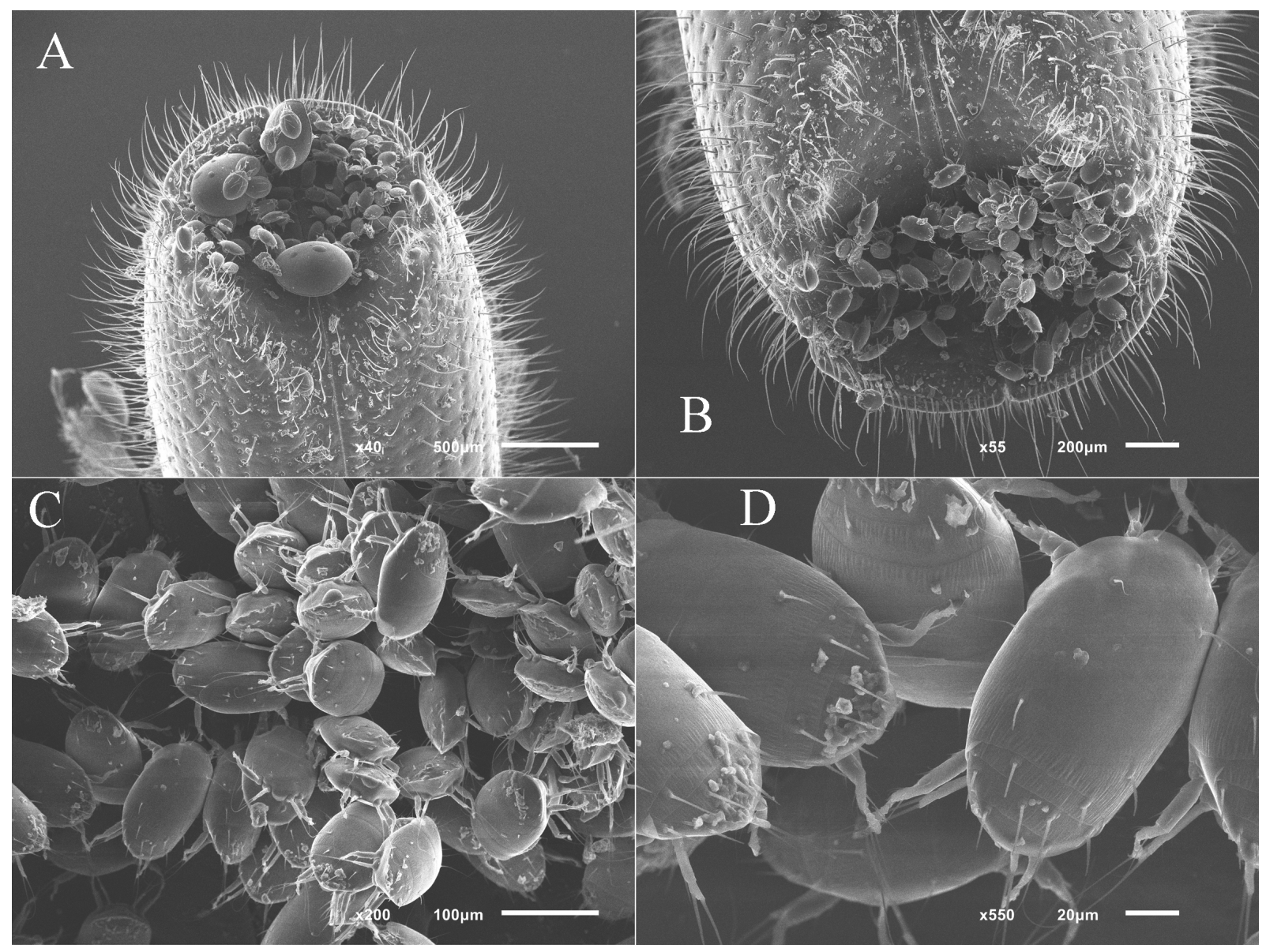

Fig. 39. SEM photographs of mites phoretic on Ips typographus. A-females of Iponemus gaebleri (small mites), deutonymphs of Uroobovella ipidis (large mites) with hyperphoretic deutonymphs of Histiostoma piceae on elytral declivity of the beetle, B-D - numerous females of Iponemus gaebleri on elytral declivity of the beetle: B-general view, C, D-detailed view.

2013). Mites are commonly associated with Ips typographus, who attack the Norway spruce $P i$ cea abies, but other bark beetle species can be involved (see below). While carried by its coleopteran hosts, phoretic deutonymphs of this mite can transport a large number of hyperphoretic ascospores of fungi that are pathogenic to the following spruce trees: Ophiostoma bicolor, Ophiostoma europhioides, Ophiostoma penicillatum, Ophiostoma polonicum, Ceratocystiopsis minuta (Moser, Perry et al. 1989). Of these fungi, Ophiostoma polonicum is the most pathogenic species, which causes obvious discoloration of the sapwood and is able to kill the host tree. Some other fungi (O. bicolor, O. europhioides) can kill considerable portions of the phloem without killing the host or causing discoloration of the sapwood (Kirisits 1998). In addition, ascospores of the fungal genus Pichia (which is commonly associated with decaying plants) were also found (Moser, Perry et al. 1989).
Feeding stages of the mite are common in bark beetle galleries when fresh boring dust is available. Deutonymphs, on the other hand, appear when the boring dust disappears (Scheucher 1957). Lab rearing without the presence of host beetles failed to produce a sustainable colony (Scheucher 1957).

Phoretic deutonymphs commonly disperse on Ips typographus (Lieutier 1978; Moser et al. 1989; Scheucher 1957; Takov et al. 2009; Wirth et al. 2016), preferring subelytral spaces (Moser and Bogenschütz 1984). Other bark beetle species can also serve as phoretic hosts: Dryocoetes hectographus (Kiełczewski and Wiśniewski 1980), Ips typographus japonicus (Moser et al. 1997), Ips cembrae (Wirth et al. 2016), Pityogenes chalcographus (Khaustov et al. 2016), Pityokteines curvidens (Pernek et al. 2008; Pernek et al. 2012), Pityokteines spinidens, Pityokteines vorontzowi (Pernek et al. 2008). Notice that the taxonomic identification of the mites from Pityokteines in Croatia (Pernek et al. 2008; Pernek et al. 2012) 


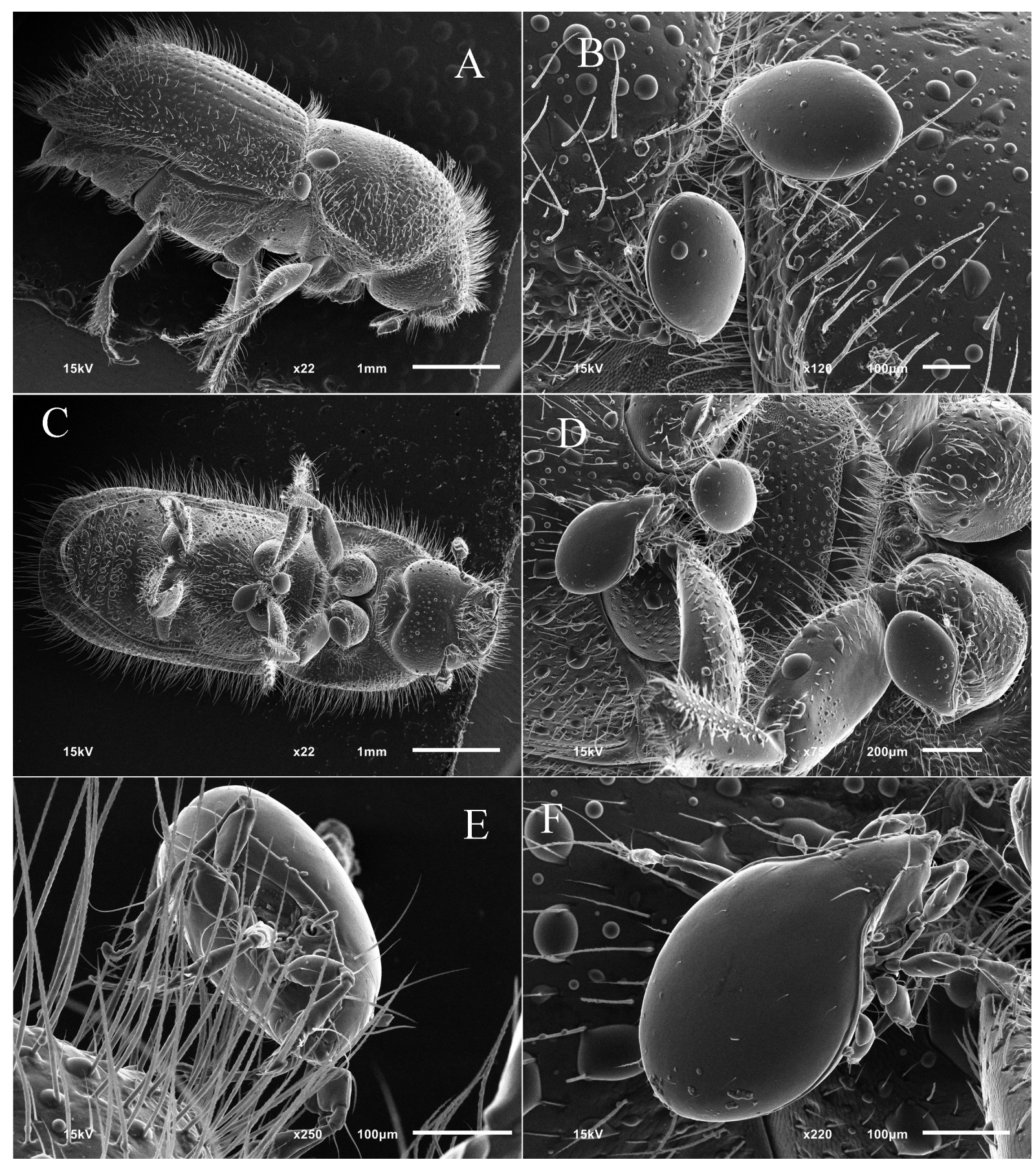

Fig. 40. SEM photographs of adults of Siculobata (Paraleius) leontonycha phoretic on Ips typographus: A, C-general view, B, D-F-detailed view.

has been questioned (Wirth and Pernek 2012). Other phoretic hosts include various beetles and mites occuring in the galleries of the following bark beetles: Staphylinidae (Scheucher 1957), Siculobata (Paraleius) leontonycha (Khaustov et al. 2016), Trichouropoda sp. and Uroobovella ipidis. Furthrerome, H. piceae is known to be hyperphoretic on the Uroobovella ipidis mite carried by the Pityogenes chalcographus beetle (Khaustov et al. 2016).
Histiostoma piceae is distributed in various countries of the Palaearctic region: Bulgaria (Takov et al. 2009), Croatia (Pernek et al. 2008; Pernek et al. 2012; Wirth et al. 2016), France (Lieutier 1978), Germany (Burjanadze et al. 2008; Moser and Bogenschütz 1984; Scheucher 1957), Japan (Moser et al. 1997), Poland (Kiełczewski and Wiśniewski 1980), Slovakia (Zamec 2013), Sweden (Moser et al. 1989; Moser, Perry et al. 1989), and Russia (Khaustov et al. 2016). There 


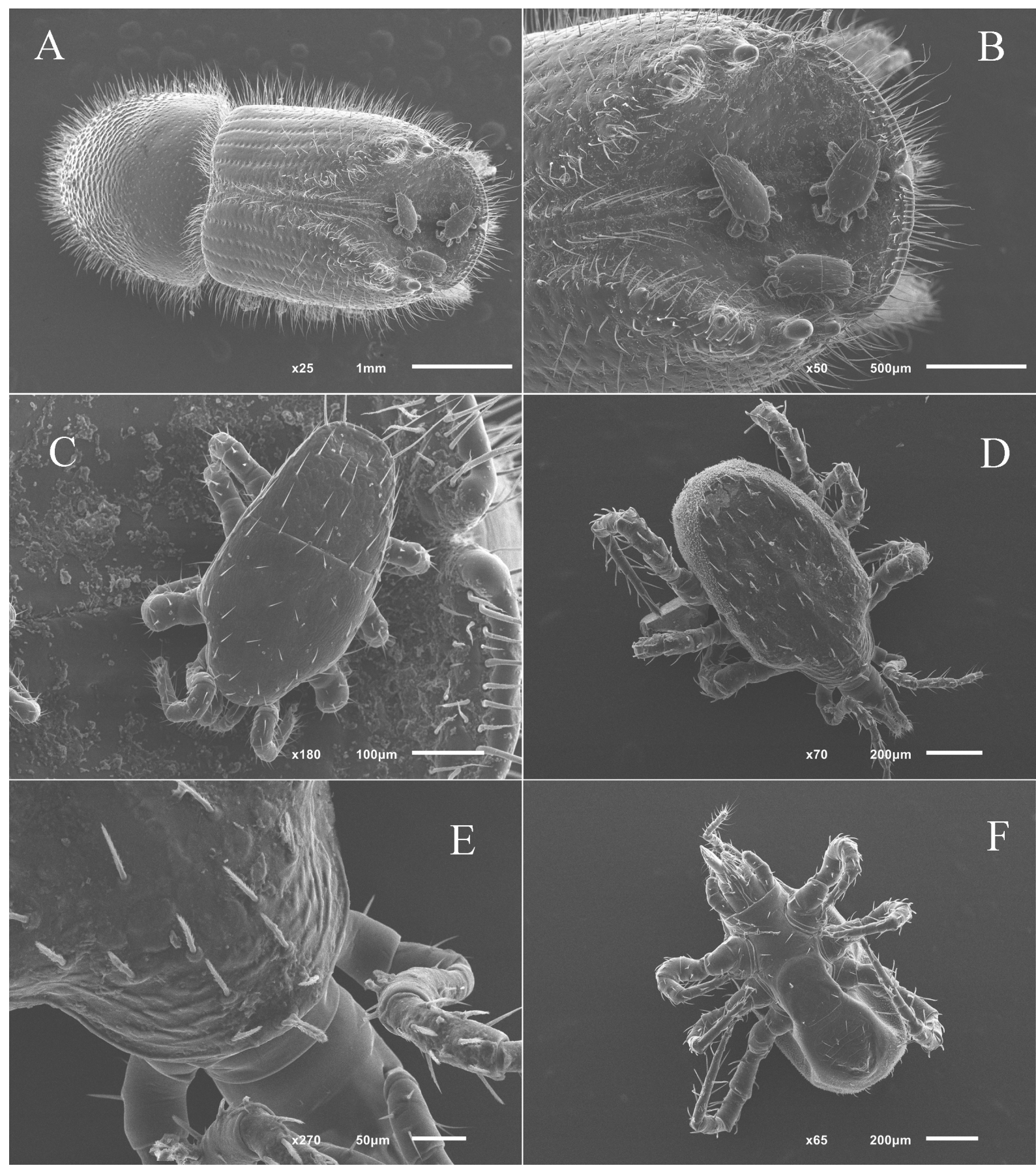

Fig. 41. SEM photographs. A-C-phoresy of deutonymphs of Dendrolaelaps (Ipidodendrolaelaps) quadrisetus on elytral declivity of Ips typographus: A — general view, B - elytral declivity with mites, C-dorsal view of mite; D-Ffemale of Macrocheles ivanovi: D_dorsal view, E-dorsal view of anterior part of the body, F-ventral view.

is a single record from Canada (Walter and Latonas 2012).

Material examined. 500+ HDNs Russia, Tyumen Region, Tyumen District, vicinity of settlement Uspenka, $57^{\circ} 04^{\prime} \mathrm{N}, 65^{\circ} 04^{\prime} \mathrm{E}$, alcohol sediments from pheromone traps for Ips typographus, 22 May 2017, coll. A.A. Khaustovsame data, 28 May 2017; same data, 5 June 2017; 15 June 2017, same data; June 2017, same data.

\section{Histiostoma pini Scheucher, 1957}

(Figs. 33A, B)

This species is a bark beetle specialist. The host range includes Hylastes ater (Mahunka 1968, 1970; Scheucher 1957), Hylastes brunneus (Kiełczewski and Wiśniewski 1980), Hylastes cunicularius (Cooreman 1963), Tomicus piniperda (Kiełczewski and Wiśniewski 1980). H. pini is known from 

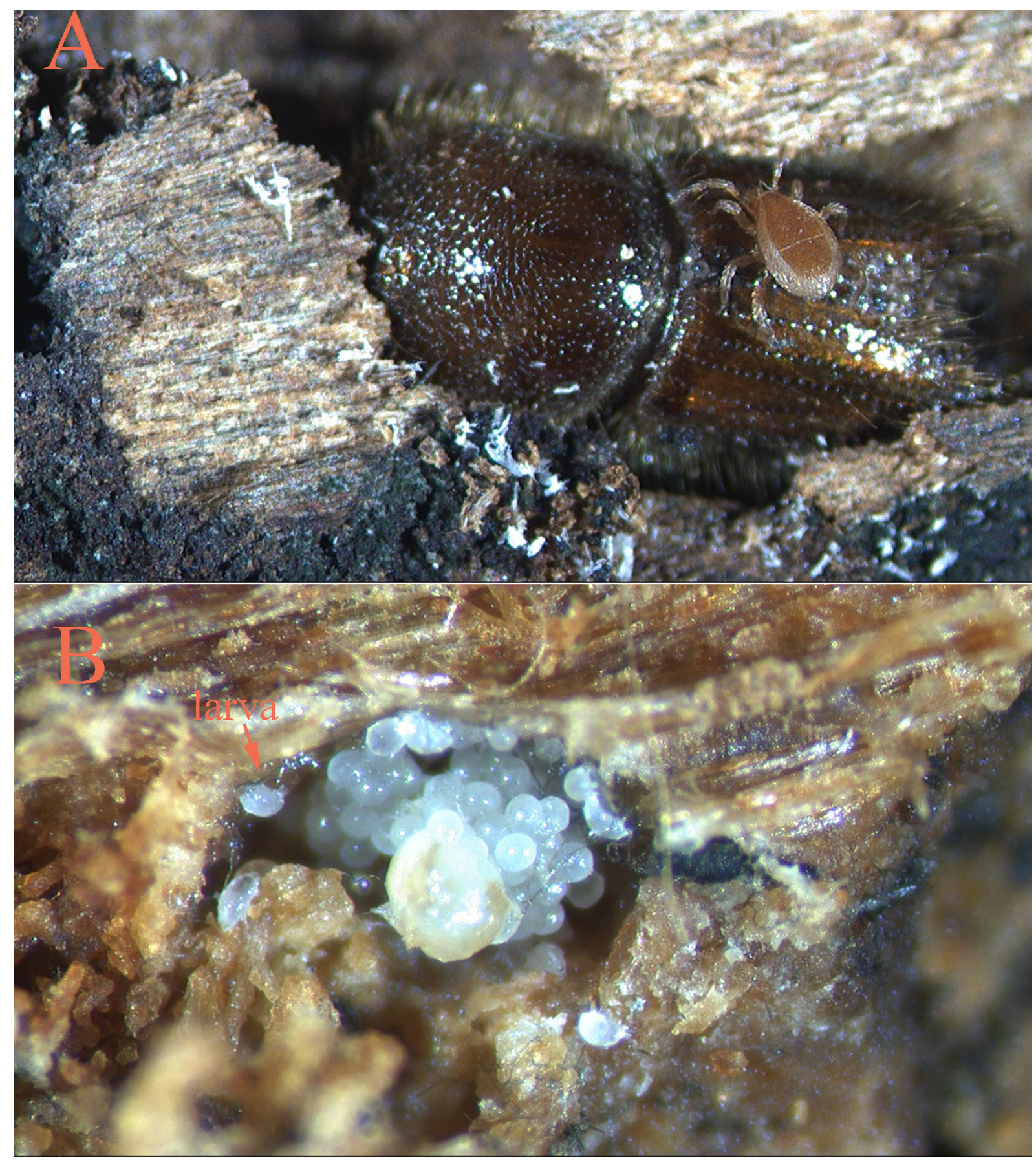

Fig. 42. A-adult of Cercoleipus kuznetsovi on Ips typographus, B-eggs and larvae of Iponemus gaebleri in the galleries of Ips typographus.

Germany (Scheucher 1957), Belgium (Cooreman 1963), Poland (Kiełczewski and Wiśniewski 1980), Hungary (Mahunka 1968, 1970), and Russia (new record).

Material examined. 100+ HDNs: Russia, Tyumen Region, Tyumen District, vicinity of settlement Uspenka, $57^{\circ} 04^{\prime} \mathrm{N}, 65^{\circ} 04^{\prime} \mathrm{E}$, alcohol sediments from pheromone traps for Ips typographus, 22 May 2017, coll. A.A. Khaustov; 05 June 2017, same data; June 2017, same data.

\section{Probonomoia pini (Scheucher, 1957)}

(Figs. 34 A, B)

This Palaearctic species typically inhabits galleries of bark beetles (Scheucher 1957), while dispersal occurs on a range of wood-visiting arthropods, including the following bark beetles: Hylastes ater (Mahunka 1970; Scheucher 1957), Ips acuminatus (Michalski and Ratajczak 1989), Ips cembrae (Wirth et al. 2016), Ips typographus (Penttinen et al. 2013; 


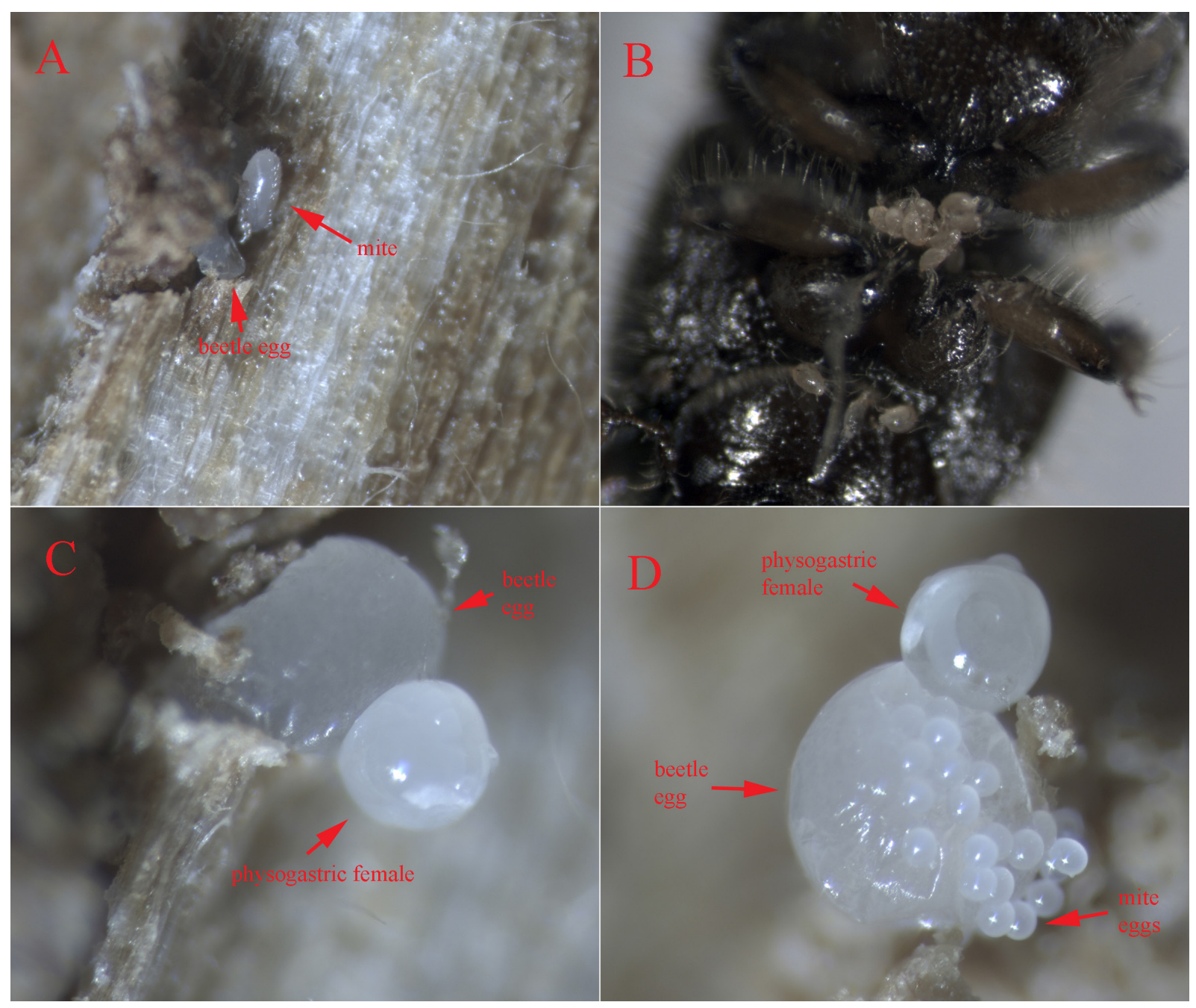

Fig. 43. A - deutonymph of Dendrolaelaps quadrisetus in the galleries of Ips typographus, B-females of Aethiophenax ipidarius phoretic on Ips typographus, C-D - feeding of female of Iponemus gaebleri on egg of Ips typographus: $\mathrm{C}$ - physogastric female of I. gaebleri on the egg of the beetle, D-physogastric female of I. gaebleri with eggs.

Wirth et al. 2016), Tomicus minor (Michalski and Ratajczak 1989), and Tomicus piniperda (Scheucher 1957). The non-bark beetle hosts are: Hylobius abietis, Pissodes pini (Ermilov et al. 2008) (Curculionidae), Acanthocinus aedilis (Ermilov and Mokrousov 2008; Samšiňák 1962; Scheucher 1957), Monochamus galloprovincialis, Rhagium inquisitor (Ermilov and Mokrousov 2008), Rosalia alpina (Haitlinger 2004), cerambycid larvae (Scheucher 1957) (Cerambycidae), Dorcus parallelipipedus (Scheucher 1957) (Lucanidae), Epuraea sp., Glischrochilus quadripunctatus (Scheucher 1957) (Nitidulidae), Myzia oblongoguttata (Scheucher 1957) (Coccinellidae), Selatosomus aeneus (Elateridae) (Ermilov et al. 2006), Thanasimus formicarius (Cleridae) (Scheucher 1957), "Helops quisquilius Sturm" (Scheucher 1957) (Tenebrionidae), Ammophila sabulosa (Ermilov and Mokrousov 2010) (Sphecidae), Crossocerus barbipes, Ectemnius gut- tatus, Ectemnius spinipes, Mellinus arvensis, Passaloecus borealis, Passaloecus eremita, Passaloecus monilicornis, Pemphredon lugens, Trypoxylon figulus, Trypoxylon medium (Ermilov and Mokrousov 2010) (Crabronidae), Myrmica laevinodis (Kiełczewski and Wiśniewski 1971), Formica rufa (Sevastianov 1970) (Formicidae), Medetera ambigua (Fain and Greenwood 1991) (Dolichopodidae), Lithobius sp. (Scheucher 1957) (Lithobiidae).

Probonomoia pini has been recorded from the following countries: Croatia (Wirth et al. 2016), the Czech Republic (Samšiňák 1962), England (Fain and Greenwood 1991), Finland (Penttinen et al. 2013), Germany (Scheucher 1957), Hungary (Mahunka 1970, 1976a), Japan (Kurosa 2000), Poland (Haitlinger 2004; Michalski and Ratajczak 1989), and Russia (Bugrov 1997; Ermilov and Mokrousov 2008, 2010; Ermilov et al. 2008; Ermilov et al. 2006; Sevastianov 1970). 

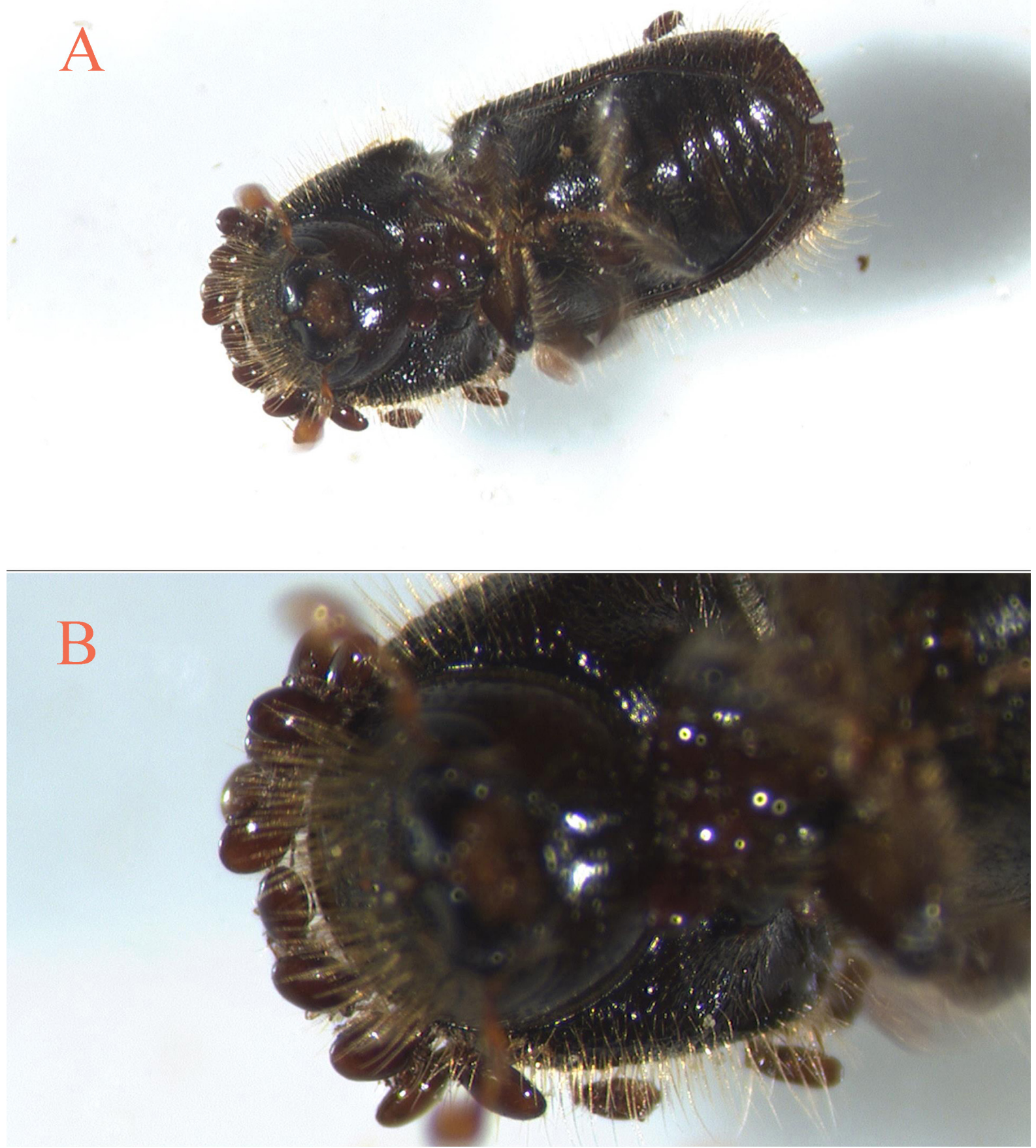

Fig. 44. A, B-adults of Siculobata leontonycha on Ips typographus.

Material examined. $1 \mathrm{HDN}$, Russia, Tyumen Region, Tyumen District, vicinity of settlement Uspenka, $57^{\circ} 04^{\prime} \mathrm{N}, 65^{\circ} 04^{\prime} \mathrm{E}$, alcohol sediments from pheromone traps for Ips typographus, 22 May 2017, coll. A.A. Khaustov; 2 HDNs, 5 June 2017, same data.

\section{Probonomoia sibirica (Wirth, 2016)}

(Figs. 34 C, D)

Phoretic deutonymphs of this species are known based on a single record from the great spruce bark beetle, Dendroctonus micans, collected in its galleries in Pinus silvestris in Russia. Feeding stages were reared in the lab (Wirth 2016). We collected this mite from Ips typographus. The deutonymph of $P$. sibirica is very similar to Probonomoia humprechti (Samšiňák, 1956) collected from the robber fly Laphria flava in the Czech Republic (Samšiňák 1956). In particular, they are similar in that the shape of the gnathosoma is trapezoidal.

Material examined. $1 \mathrm{HDN}$, Russia, Tyumen Region, Tyumen District, vicinity of settlement 
Uspenka, $57^{\circ} 04^{\prime} \mathrm{N}, 65^{\circ} 04^{\prime} \mathrm{E}$, alcohol sediments from pheromone traps for Ips typographus, 15 June 2017, coll. A.A. Khaustov.

\section{PHORESY OF MITES ON IPS TYPOGRAPHUS}

Using pheromone traps, we collected a total of 13,451 individuals of Ips typographus and a broad range of associated mites belonging to 60 species (Table 1). Six of them, Siculobata leontonycha (35.44\%), Uroobovella ipidis (13.01\%), Trichouropoda polytricha (8.13\%), Dendrolaelaps quadrisetus $(20.57 \%)$, Histiostoma piceae (10.04\%), and Iponemus gaebleri (8.92\%) were dominant and together represented $96 \%$ of all collected mites. Trichouropoda karawaiewi, Schwiebea nova, Histiostoma pini, Aethiophenax ipidarius, Elattoma crossi, Coleopygmephorus hylophilus, Tarsonemus striatus, Tarsonemus typographi, Ipsoglyphus bochkovi, Naiadacarus sp., and Schwiebea sp.1 nova-group were subdominants, representing together nearly $3 \%$ of all collected mites. Other mite species were collected in low numbers.

Some species had specific phoretic attachment sites on bark beetle bodies. Deutonymphs of Trichouropoda polytricha and Uroobovella ipidis mainly attached to the ventral thorax and elytral declivity of the beetle. More rarely, they attached to the legs and head. Females of Elattoma crossi and Aethyophenax ipidarius always attached between coxae I and II of the beetle. Females of Iponemus gaebleri usually attached to the elytral declivity of the beetle. In cases when large phoretic deutonymphs of uropodid mites also attached to the elytral declivity, tiny tarsonemids hid under large mites. Deutonymphs of Histiostoma picea prefered to attach to the elytral declivity and abdomen of the beetle, but if the number of phoretic mite was large, they could attach to any part of the body, as well as to other phoretic mites (hyperphoresy). Deutonymphs of Dendrolaelaps quadrisetus were usually phoretic under the elytra of the beetles, but sometimes also on the elytral declivity. Adults of Siculobata leontonycha attached to the long hairs of the beetle on the head, thorax or legs. Females of Ereynetes sp. and deutonymphs of Schizosthetus sp. were observed actively moving around the beetle body.

\section{ACKNOWLEDGEMENTS}

The authors thank Dr. Sergey Ermilov (Tyumen State University, Russia) for the identification of the oribatid mite, and Dr. S.F. Wirth (Berlin, Germany) for the identification of Histiostoma piceae. We thank Barry OConnor (University of Michigan, Museum of Zoology_UMMZ) for confirming our identification of several astigmatid species. The present research was supported by the grant from the Russian Science Foundation, project No. 1614-10109 to Dr. A.A. Khaustov.

\section{REFERENCES}

Ahadiyat, A. and Akrami, M.A. 2015. Oribatid mites (Acari: Oribatida) associated with bark beetles (Coleoptera: Curculionidae: Scolytinae) in Iran, with a review on Paraleius leontonychus (Berlese) and a list of bark beetles in association with this species. Persian Journal of Acarology, 4: 355-371.

Ahadiyat, A., Khaustov, A.A., Seeman, O.D. and Valizadeh, A. 2011. First record of mites of the genus Cercoleipus Kinn, 1970 (Mesostigmata: Trigynaspida: Cercomegistidae) from Iran. In: S. Kazemi and A. Saboori (Eds.). Abstract and Proceeding Book of the First Persian Congress of Acarology, Kerman, Iran, p. 2.

Ahadiyat, A., Ostovan, H., Gwiazdowicz, D. and Valizadeh, A. 2012. Celaenopsid mites (Mesostigmata) associated with the Mediterranean pine engraver beetle, Orthotomicus erosus (Wollaston) (Coleoptera: Curculionidae: Scolytinae), in Iran. In: A. Sarafrazi, M. R. Asef, M. Mozhdehi, M. Mozhdehi, S. Solhjouy Fard and T. Abdollahi (Eds.). Proceedings of the $20^{\text {th }}$ Iranian Plant Protection Congress. 26-29 August 2012. Shiraz University, Iran, p. 475.

Al-Atawi, F., Klompen, H. and Moser, J.C. 2002. Redescription of Schizosthetus lyriformis (McGraw and Farrier, 1969) (Parasitiformes: Parasitidae), with revision of the genus. International Journal of Acarology, 28: 341-360.

Alekseev, G.A., Marchenko, I.I., Savvinov, G.N. and Boeskorov, V.S. 2011. Soil gamasid mites (Acari: Mesostigmata) of Central Yakutia. In: V.E. Kipyatkov and D.L. Musolin (Eds.). Materials of the International Scientific Conference "Fundamental Problems of Entomology in the $21^{\text {st }}$ Century" (16-20 May 2011, Saint Petersburg, Russia). St. Petersburg University, Saint Petersburg, p. 7.

André, M. 1942. Sur l'Hemisarcoptes malus Shimer (=coccisugus Lignières). Bulletin du Muséum national d'histoire naturelle. $2^{\text {ème }}$ Série, 14: 173180.

Arlian, L.G., Geis, D.P., Vyszenski-Moher, D.L., Bernstein, I.L. and Gallagher, J.S. 1984. Antigenic and allergenic properties of the storage mite Tyrophagus putrescentiae. Journal of Allergy and Clinical Immunology, 74: 166-171. 
Athias-Henriot, C. 1959. Contribution to the genera Podocinum Berlese and Pleuronectocelaeno Vitzthum in Algeria and notes on the genus Aceosejus Sellnick and Seiodes Berlese (Mesostigmata). Acarologia, 1: 24-38.

Athias-Henriot, C. 1982. Schizosthetus n.g. (type Eugamasus lyriformis McGr. \& Farr., 1969) avec deux espèces nouvelles (Parasitiformes, Parasitidae). Acarologia, 23: 207-214.

Baker, E.W. 1949. A review of the mites of the family Cheyletidae in the United States National Museum. Proceedings of the United States National Museum, 99: 267-320.

Balazy, S. and Kiełczewski, B. 1965. Tarsonemoides gaebleri Schaarschmidt (Acar. Tarsonemidae) jajozerny roztocz w zerowiskach kornika drukarza Ips typographus (L.). Polskie Pismo Entomologiczne B, 37/38: 7-18.

Bayoumi, B.M. and Al-Khalifa, M.S. 1983. Soil mites and Collembola from Al-Quasim Province, Saudi Arabia. Arab Gulf Journal of Scientific Research, 1: 179-186.

Berlese, A. 1920 (1921). Centuria quinta di Acari nuovi. Redia, 14: 143-195.

Berlese, A. 1903 (1904). Acari nuovi. Manip. II. Redia, 1: 258-280.

Bochkov, A.V. and Abramov, V.V. 2016. To fauna of the free-living Cheyletidae (Acariformes: Cheyletoidea) of the European part of Russia. Systematic and Applied Acarology, 21:335-346.

Brasier, C.M. 1978. Mites and reproduction in Ceratocystis ulmi and other fungi. Transactions of the British Mycological Society, 70: 81-89.

Bregetova, N.G. 1977a. [Family Aceosejidae]. In: M.S. Gilarov and N.G. Bregetova (Eds.). Opredelitel' obytayshchikh v pochve kleshchey Mesostigmata [Identification key to soil-inhabiting mites Mesostigmata]. Nauka, Leningrad, pp. 169-226.

Bregetova, N.G. 1977b. [Family Macrochelidae]. In: M.S. Gilarov and N.G. Bregetova (Eds.). Opredelitel' obytayshchikh v pochve kleshchey Mesostigmata [Identification key to soil-inhabiting mites Mesostigmata]. Nauka, Leningrad, pp. 346-411.

Bregetova, N.G. and Koroleva, E.V. 1960. The macrochelid mites (Gamasoidea, Macrochelidae) of the USSR. Parazitologicheskiy Sbornik, 19: 32-154.

Bugrov, S.A. 1995. [New species of the genus Schwiebea (Astigmata, Acaridae) from Russia and adjacent countries]. Zoologicheskii Zhurnal, 74: 61-75.

Bugrov, S.A. 1997. [Free-living Astigmata (Acariformes) of the Moscow District fauna]. Zoologicheskii Zhurnal, 76: 147-156.

Burjanadze, M., Moser, J.C., Zimmermann, G. and Kleespies, R.G. 2008. Antagonists of the spruce bark beetle Ips typographus L. (Coleoptera: Scolytidae) of German and Georgian populations. IOBC-WPRS Bulletin, 31: 245-250.

Castagnoli, M., Liguori, M. and Nannelli, R. 1994. Mite communities associated with chestnut blight. Atti del Congresso Nazionale Italiano di Entomologia, 17: 465-468.

Čejka, M. and Holuša, J. 2014. Phoretic mites in uniand bivoltine populations of Ips typographus: a 1-year case study. Turkish Journal of Zoology, 38: 569-574.

Černý, V. and Samšiňák, K. 1971. Nadkohorta Acaridiae. In: M. Daniel and V. Černý (Eds.). Klíč zvířeny ČSR. Želvušky, jazyčnatky, klepítkatci, sekáči, pavouci, štírci, roztoči. Československá Akademie Věd, Praha, pp. 496-529.

Chaires-Grijalva, M.P., Estrada-Venegas, E.G., Equihua-Martinez, A., Moser, J.C., Sanchez-Martinez, G., Vazquez-Rojas, I.M. et al. 2013. Mesostigmados (Acari: Mesostigmata) asociados con Dendroctonus rhizophagus de Chihuahua, Mexico. Revista Mexicana de Biodiversidad, 84: 1235-1242.

Chant, D.A. 1963. The subfamily Blattisocinae Garman (=Aceosejinae Evans) (Acarina: Blattisocidae Garman) (=Aceosejidae Baker \& Wharton) in North America, with descriptions of new species. Canadian Journal of Zoology, 41: 243-305.

Chmielewski, W. 1969. Obserwacje nad biologią nowego dla akarofauny polskiej gatunku Kuzinia laevis (Dujardin, 1849) (Acarina, Acaridae) [=Observations on the biology of the species Kuzinia laevis (Dujardin, 1849) (Acarina, Acaridae), new in Polish acarofauna]. Polskie Pismo Entomologiczne. Bulletin Entomologique de Pologne, 39: 603-617.

Chmielewski, W. 1975. Z badań nad Thyreophagus entomophagus (Laboulbène). Zeszyty Problemowe Postępów Nauk Rolniczych, 171: 253-259.

Chmielewski, W. 1977. Wyniki obserwacji powiazan roztoczy z owadami (Acari-Insecta). Polskie Pismo Entomologiczne, 47: 59-78.

Chmielewski, W. 1991. Stored products mites (Acaroidea) in Polish bee hives. In: Modern acarology. Volume I: proceedings of the 8 International Congress of Acarology, held in Ceske Budejovice, Czechoslovakia, 6-11 August 1990. SPB Academic Publishing, The Hague, The Netherlands, pp. 615-619.

Cooreman, J. 1963. Notes et observations sur quelques Acariens inféodés aux Coléoptères Scolytides de la faune belge. Bulletin de l'Institut Royal des Sciences Naturelles de Belgique-Bulletin van het Koninklijk Belgisch Instituut voor Natuurwetenschappen, 39: 1-48. 
Cotter, M., Siebers, R., Pike, A., Fitzharris, P. and Crane, J. 2011. Storage mites in flour samples in Wellington, New Zealand. Journal of Investigational Allergology and Clinical Immunology, 21: 410-411.

Cross, E.A. and Moser, J.C. 1971. Taxonomy and biology of some Pyemotidae (Acarina: Tarsonemoidea) inhabiting bark beetle galleries in North American conifers. Acarologia, 13: 47-64.

Cross, E.A., Moser, J.C. and Rack, G. 1981. Some new forms of Pyemotes (Acarina: Pyemotidae) from forest insects, with remarks on polymorphism. International Journal of Acarology, 7: 179-196.

Davydova, M.S. and Nikolskii, V.V. 1986. Gamazovye kleshchi Zapadnoi Sibiri. [Gamasid mites of Western Siberia.]. Novosibirsk, Nauka. 1-123 pp.

De Camargo Barbosa, M.F., OConnor, B.M. and De Moraes, G.J. 2016. A new species of Thyreophagus (Acari: Acaridae) from Brazil, with notes on species associated with stored food and human habitats and a key to species of this genus. Zootaxa, 4088: 279-291.

de la Torre Morin, F., de la Coba, R.A., Gallego, M., Iraola, V. and Fernandez-Caldas, E. 2006. Sensitization to Thyreophagus entomophagus and other mite species in Cuban patients with allergic asthma and/or rhinoconjunctivitis. Journal of Allergy and Clinical Immunology, 117: S119-S119.

De Moraes, G.J., Britto, E.P.J., Mineiro, J.L.D.C. and Halliday, B. 2016. Catalogue of the mite families Ascidae Voigts \& Oudemans, Blattisociidae Garman and Melicharidae Hirschmann (Acari: Mesostigmata). Zootaxa, 4112: 1-276.

Dobrev, D. and Mahunka, S. 1991. Data to the scutacarid fauna of the Bátorliget nature conservation areas (Acari: Heterostigmata). In: The Bátorliget Nature Reserves-after forty years. Hungarian Natural History Museum, Budapest, pp. 719-726.

Domrow, R. 1992. Acari Astigmata (excluding feather mites) parasitic on Australian vertebrates: an annotated checklist, keys and bibliography. Invertebrate Taxonomy, 6: 1459-1606.

Dzibladze, K. N. 1969. Anew species of predatory mite (Hemisarcoptidae) attacking the orange scale, Cornuaspis beckii Newman (Homoptera, Coccoidea), in Western Georgia. Entomologicheskoe Obozrenie, 48: 435-436.

Elkawas, H. 2011. Acarines As Biological Control Agents: An Overview of Bio-relationships between Mites and Insects in Egypt LAP LAMBERT Academic Publishing. 1-128 pp.

Erban, T., Rybanska, D., Harant, K., Hortova, B. and Hubert, J. 2016. Feces derived allergens of Tyrophagus putrescentiae reared on dried dog food and evidence of the strong nutritional interaction between the mite and Bacillus cereus producing protease bacillolysins and exo-chitinases. Frontiers in Physiology, 7.

Ermilov, S.G. and Mokrousov, M.V. 2008. Acariform mites (Acariformes) phoresing on capricorn beetles (Coleoptera, Cerambycidae). Povolzhskii Ekologicheskii Zhurnal, 3: 222-225.

Ermilov, S.G. and Mokrousov, M.V. 2010. Mites phoretic on wasps (Hymenoptera: Ampulicidae, Sphecidae, Crabronidae) in the middle Volga region. Entomoligicheskie i parazitplogicheskie issledovaniya $v$ Povolzh'e, 8: 85-95.

Ermilov, S.G., Mokrousov, M.V. and Dmitrieva, I.N. 2008. Snout beetle acarofauna (Coleoptera, Curculionoidea). Povolzhskii Ekologicheskii Zhurnal, 1: 65-68.

Ermilov, S.G., Mokrousov, M.V. and Mukhanov, A.V. 2006. Phoretic associations between acariform mites (Acariformes) and click beetles (Coleoptera, Elateridae). Povolzhskii Ekologicheskii Zhurnal, 2/3: 176-179.

Ermilov, S.G., Mokrousov, M.V. and Mukhanov, A.V. 2007. Acarofauna of bark beetles (Coleoptera, Scolytidae) in the Nizhniy Novgorod region. Povolzhskiy Journal of Ecology, 1: 67-70.

Evans, G.O. 1958. A revision of the British Aceosejinae (Acarina: Mesostigmata). Proceedings of the Zoological Society of London, 131: 177-229.

Fain, A. 1972. Notes sur les hypopes des Saproglyphidae (Acarina: Sarcoptiformes) 2. Redefinition des genres. Acarologia, 14: 225-249.

Fain, A. 1974. Observations sur la faune acarologique du sol dans une savane de Côte d'Ivoire (Acaridae: Sarcoptiformes). Bulletin de l'Institut Fondamental de l'Afrique Noire Série A, 36: 69-91.

Fain, A. 1977. Notes sur le genre Schwiebea Oudemans, 1916 (Acarina, Astigmata, Acaridae). Bulletin \& Annales de la Societe Royale Belge d'Entomologie, 113: 251-276.

Fain, A. 1982. Revision des genres Thyreophagus Rondani, 1874 et Michaelopus Fain \& Johnston, 1974 (Acari, Acaridae) avec description de neuf especes nouvelles. Bulletin de l'Institut Royal des Sciences Naturelles de Belgique Entomologie, 54: $1-47$.

Fain, A. 1987. Observations on the hypopi of the genus Forcellinia Oudemans, 1924 (Acari, Acaridae). Bulletin de l'Institut Royal des Sciences Naturelles de Belgique Entomologie, 57: 111-120.

Fain, A. 1988. Observations on Congovidia Fain \& Elsen, 1971 and allied genera (Acari, Hemisarcoptidae). Bulletin \& Annales de la Societe Royale Belge d'Entomologie, 124: 125-130. 
Fain, A. and Baugnee, J.Y. 1996. Acariens phorétiques ou parasites récoltés sur des insectes du sud de la Belgique. Deuxième note. Bulletin et Annales de la Societe Royale Belge d'Entomologie, 132: 19-33.

Fain, A. and Beaucournu, J.C. 1972. Notes sur les hypopes vivant en association phorétique sur les puces en France (Acarina: Sarcoptiformes). Acarologia, 13: 522-531.

Fain, A. and Beaucournu, J.C. 1993. Les hypopes des astigmates (Acari) phoretiques sur les puces (Siphonaptera) de mammiferes et d'oiseaux. Bulletin de l'Institut Royal des Sciences Naturelles de Belgique Entomologie, 63: 77-93.

Fain, A. and Greenwood, M.T. 1991. Notes on a small collection of mites (Acari), phoretic on Diptera, mainly Phoridae, from the British Isles. Bulletin de l'Institut Royal des Sciences Naturelles de Belgique Entomologie, 61: 193-197.

Fain, A., Hurst, G.D.D., Fassotte, C., Webberley, K.M., Sloggett, J.J. and Majerus, M.E.N. 1997. New observations on the mites of the family Hemisarcoptidae (Acari: Astigmata) phoretic on Coccinellidae (Coleoptera). Bulletin de l'Institut Royal des Sciences Naturelles de Belgique Entomologie, 67: 89-94.

Fain, A., Hurst, G.D.D., Tweddle, J.C., Lachlan, R.F., Majerus, M.E.N. and Britt, D.P. 1995. Description and observations of two new species of Hemisarcoptidae from deutonymphs phoretic on Coccinellidae (Coleoptera) in Britain. International Journal of Acarology, 21: 99-106.

Fain, A. and Johnston, D. 1974. Three new species of hypopi phoretic on springtails (Collembola) in England (Acari: Acarididae). Journal of Natural History, 8: 411-420.

Fain, A., Knuelle, W. and Wurst, E. 2000. First description of the hypopial stage of Thyreophagus entomophagus (Laboulbène, 1852) (Acari Acaridae). Bulletin de la Societe Royale Belge d'Entomologie, 136: 153-156.

Fain, A. and Rack, G. 1987. Allocalvolia habrocytus gen.n., sp.n. (Acari, Winterschmidtiidae) a new hypopus phoretic on Habrocytus elevatus (Walker 1834) (Hymenoptera, Pteromalidae) in Austria. Entomologische Mitteilungen aus dem Zoologischen Staatsinstitut und Zoologischen Museum Hamburg, 8: 309-341.

Fain, A. and Ripka, G. 1998. A new species of Hemisarcoptes Lignières, 1893 (Acari: Hemisarcoptidae) from ornamental trees in Hungary. International Journal of Acarology, 24: 33-39.

Fain, A. and Schwan, T.G. 1984. Three new hypopial nymphs (Acari: Acaridae) phoretic on fleas parasitic on rodents in California, USA. Bulletin \&
Annales de la Societe Royale Belge d'Entomologie, 120: 91-97.

Fashing, N.J. 1975. Life history and general biology of Naiadacarus arboricola Fashing, a mite inhabiting water-filled treeholes (Acarina: Acaridae). Journal of Natural History, 9: 413-424.

Fashing, N.J. and Chua, T.H. 2002. Systematics and ecology of Naiadacarus nepenthicola, a new species of Acaridae (Acari: Astigmata) inhabiting the pitchers of Nepenthes bicalcarata Hook. f. in Brunei Darussalam. International Journal of Acarology, 28: 157-167.

Feketeová, Z. 2011. Význam uropodných roztočov (Acari: Uropodina) v ekológii lykožrúta smrekového (Ips typographus). Entomofauna carpathica, 23: 11-19.

Fernández, M., Julio, D. and Moraza, M.L. 2013. Acarofauna associated with Ips sexdentatus in northwest Spain. Scandinavian Journal of Forest Research, 28: 358-362.

Fumouze, A. and Robin, C. 1867. Mémoire anatomique et zoologique sur les Acariens des genres Cheyletus, Glyciphagus et Tyroglyphus. Journal de l' anatomie et de la physiologie normales et pathologiques de l'homme et des animaux, 4: 561-601+Pl. XXIIXXV.

Gerson, U. and Schneider, R. 1981. Laboratory and field studies on the mite Hemisarcoptes coccophagus Meyer (Astigmata: Hemisarcoptidae), a natural enemy of armored scale insects. Acarologia, 22: 199-208.

Goracci, E., Lazzeri, S., Zuccherelli, D., Rossetti, M. and Poggianti, A.M. 1985. [Acari of food storage facilities. An ecologic and immuno-allergic study]. Quaderni Sclavo di diagnostica clinica e di laboratorio, 21: 436-446.

Gorton, C. and Webber, J.F. 2000. Reevaluation of the status of the bluestain fungus and bark beetle associate Ophiostoma minus. Mycologia, 92: 10711079.

Griffiths, D.A. 1964. A revision of the genus Acarus L. 1758 (Acaridae, Acarina). Bulletin of the British Museum (Natural History) Zoology, 11: 413-464.

Griffiths, D.A. 1970. A further systematic study of the genus Acarus L., 1758 (Acaridae, Acarina), with a key to species. Bulletin of the British Museum (Natural History) Zoology, 19: 85-118.

Griffiths, D.A., Hodson, A.C. and Christensen, C.M. 1959. Grain storage fungi associated with mites. Journal of Economic Entomology, 52: 514-518.

Grobov, O.F. 1978. Kleshchi medonosnoy pchely (Apis mellifera $\mathrm{L}$.): ikh znachenie i osnovnue printsypy bor'by s kleschchevymi porazheniyami [=-Mites of the honeybee (Apis mellifera $\mathrm{L}$.): their significance 
and main principles of control of diseases caused by mites]. Doctor of Sciences (Habilitation) Thesis. In: All-Union Institute of Experimental Veterinary, All-Union Academy of Agricultural Sciences, Moscow, p. 536.

Gwiazdowicz, D.J. 2007. Ascid Mites (Acari, Mesostigmata) from Selected Forest Ecosystems and Microhabitats in Poland. Poznan, Wydawnictwo Akademii Rolniczej im. Augusta Cieszkowskiego, 2007. 247 pp.

Gwiazdowicz, D.J. 2008. Mesostigmatid mites (Acari) associated with Scolytidae in Poland. In: D.J. Gwiazdowicz (Ed.). Selected problems of acarological research in forests. Wydawnictwo Uniwersytetu Przyrodniczego, Poznan, pp. 59-95.

Gwiazdowicz, D.J., Bloszyk, J. and Gdula, A.K. 2015. Alpha diversity of mesostigmatid mites associated with the bark beetle Ips typographus (L.) in Poland. Insect Conservation and Diversity, 8: 448-455.

Gwiazdowicz, D.J. and Gutowski, J.M. 2012. Records of phoretic mesostigmatid mites (Acari: Mesostigmata) on beetles (Coleoptera: Carabidae, Cerambycidae, Elateridae, Erotylidae, Scolytinae) in the Białowieża Primeval Forest. Polskie pismo entomologiczne, 81: 305-310.

Gwiazdowicz, D.J., Kamczyc, J. and Bloszyk, J. 2011. The diversity of phoretic Mesostigmata on Ips typographus (Coleoptera: Scolytinae) caught in the Karkonosze forest. European Journal of Entomology, 108: 489-491.

Gwiazdowicz, D.J., Kamczyc, J., Teodorowicz, E. and Bloszyk, J. 2012. Mite communities (Acari, Mesostigmata) associated with Ips typographus (Coleoptera, Scolytidae) in managed and natural Norway spruce stands in Central Europe. Central European Journal of Biology, 7: 910-916.

Gwiazdowicz, D.J. and Walter, D.E. 2005. Gamasellodes tatricus sp. nov. (Acari: Ascidae) from Poland. Systematic and Applied Acarology, 10: 61-66.

Haddad Irani Nejad, K., Kamali, K. and Maleki Milani, H. 2001. Mites of Digamasellidae, Rhodacaridae, Phytoseiidae and Ascidae of the cooton fields in Moghan Plain. Agricultural Sciences and Technology, 15 23-33.

Haitlinger, R. 1988. Mites (Acari) occurring on beetles of the genus Carabus Linnaeus, 1758 (Insecta, Coleoptera, Carabidae). Wiadomości Parazytologiczne, 34: 329-346.

Haitlinger, R. 2004. Mites (Acari) occurring on some Coleoptera (Insecta) in Poland. Polskie Pismo Entomologiczne, 73: 3-24.

Haitlinger, R. and Lupicki, D. 2012. Mites (Acari) occurring on some Coleoptera and Diptera in Poland.
Zeszyty Naukowe Uniwersytetu Przyrodniczego we Wroclawiu, 587: 17-48.

Halliday, R.B. 2000. Additions and corrections to Mites of Australia: A checklist and bibliography. Australian Journal of Entomology, 39: 233-235.

Halliday, R.B. 2002. Two genera of mites new to the Australian fauna (Acari: Acaridae). Australian Entomologist, 29: 119-122.

Hirschmann, W. 1960. Gangsystematik der Parasitiformes. Teil 3. Die Gattung Dendrolaelaps Halbert 1915. Acarologie. Schriftenreihe für Vergleichende Milbenkunde, 3: 1-27.

Hirschmann, W. 1970. Ruckenhaarbestimmungstabelle der larven von Macrocheles und verwandten gattungen (Geholaspis, Neopodocinum). Teil 77. Acarologie. Schriftenreihe für Vergleichende Milbenkunde, 14: 44-45.

Hirschmann, W. and Wiśniewski, J. 1982. Weltweite Revision der Gattungen Dendrolaelaps Halbert 1915 und Longoseius Chant 1961 (Parasitiformes). Band II. Artenverzeichnisse, Krankheiten, Mißbildungen, Inseminationsapparate, Abbildungen. Acarologie. Schriftenreihe für Vergleichende Milbenkunde, 29: 1-48, pls. I-XIV, 41-94.

Hofstetter, R.W. 2011. Mutualists and phoronts of the southern pine beetle. In: R.N. Coulson and K.D. Klepzig (Eds.). Southern Pine Beetle II. Gen. Tech. Rep. SRS-140. U.S. Department of Agriculture Forest Service, Southern Research Station, Asheville, NC, pp. 161-181.

Hofstetter, R.W., Dinkins-Bookwalter, J., Davis, T.S. and Klepzig, K.D. 2015. Chapter 6-Symbiotic Associations of Bark Beetles. In: F.E.V. Vega and R.W. Hofstetter (Eds.). Bark Beetles: Biology and Ecology of Native and Invasive Species. Academic Press, San Diego, pp. 209-245.

Hofstetter, R.W., Moser, J.C. and Blomquist, S.R. 2013. Mites associated with bark beetles and their hyperphoretic ophiostomatoid fungi. Ophiostomatoid Fungi: expanding Frontiers. CBS Biodiversity Series, 12: 165-176.

Hofstetter, R.W., Moser, J.C. and McGuire, R. 2009. Observations on the mite Schizosthetus lyriformis (Acari: Parasitidae) preying on bark beetle eggs and larvae. Entomological News, 120: 397-400.

Houck, M.A. 1994. Adaptation and transition into parasitism from commensalism: a phoretic model. In: M.A. Houck (Ed.). Mites: Ecological and Evolutionary Analyses of Life-history Patterns. Chapman \& Hall, New York \& London, pp. 252-281.

Houck, M.A. 1999. Phoresy by Hemisarcoptes (Acari: Hemisarcoptidae) on Chilocorus (Coleoptera: Coccinellidae): influence of subelytral ultrastructure. Experimental and Applied Acarology, 23: 97-118. 
Houck, M.A. and Cohen, A.C. 1995. The potential role of phoresy in the evolution of parasitism: Radiolabelling (tritium) evidence from an astigmatid mite. Experimental \& Applied Acarology, 19: 677-694.

Hughes, A.M. 1976. The Mites of Stored Food and Houses. London, Her Majesty's Stationery Office. $400 \mathrm{pp}$.

Hunter, P.E. and Davis, R. 1963. Observations on Histiostoma gordius (Vitz.) (Anoetidae) and other mites associated with Ips beetles. Proceedings of the Entomological Society of Washington, 65: 287-293.

Hurlbutt, H.W. 1967. Digamasellid mites associated with bark beetles and litter in North America. Acarologia, 9: 497-534.

Hurlbutt, H.W. 1971. Gamasellodes bicolor (Berlese, 1918) (Acarina: Ascidae) and its relatives. Acarologia, 12: 476-478.

Hutcheson, H.J., Mertins, J.W., Larson, S.R. and Paskewitz, S. 2015. Acarine hypopi (Sarcoptiformes: Acaridae) on Ixodes scapularis (Ixodida: Ixodidae) in Central North America. Journal of Medical Entomology, 52: 837-841.

Iglesias-Souto, J., Sanchez-Machin, I., Iraola, V., Poza, P., Gonzalez, R. and Matheu, V. 2009. Oral mite anaphylaxis by Thyreophagus entomophagus in a child: a case report. Clinical and Molecular Allergy, 7: 10.

Kadjaia, G.S. 1994. Geographical variability in the Caucasian species of the genus Forcellinia (Acari: Acaridae). Zoosystematica Rossica, 3: 235-236.

Kaliszewski, M., Athias-Binche, F. and Lindquist, E.E. 1995. Parasitism and parasitoidism in Tarsonemina (Acari: Heterostigmata) and evolutionary considerations. In: R.M.J.R. Baker and D. Rollinson (Eds.). Advances in Parasitology. Academic Press, pp. 335-367.

Kalúz, S., Mašán, P. and Moser, J. C. 2003. Morphology and ecology of Schizosthetus simulatrix (Acari, Mesostigmata) associated with galleries of bark beetles (Scolytidae). Biologia (Bratislava), 58: 165-172.

Kamali, K., Ostovan, H. and Atamehr, A. 2001. A Catalog of Mites and Ticks (Acari) of Iran. Islamic Azad University Scientific Publication Center. 1-196 pp.

Karg, W. 1993. Acari (Acarina), Milben. Parasitiformes (Anactinochaeta). Cohors Gamasina Leach: Raubmilben. $2^{\text {nd }}$ edition. Jena, Gustav Fischer Verlag. 1-523 pp.

Kazemi, S. and Rajaei, A. 2013. An annotated checklist of Iranian Mesostigmata (Acari), excluding the family Phytoseiidae. Persian Journal of Acarology, 2: $63-158$.
Khaustov, A.A. 1997. [Mites of supercohort Trigynaspida (Parasitiformes. Celaenopsidae, Cercomegistidae) associated with bark beetles (Coleoptera, Scolytidae) of the Crimea]. Biulleten'-Gosudarstvennyı̌ Nikitskiǔ botanicheskiǔ sad, 78: 63-66. [In Russian]

Khaustov,A.A. 1998. Mites of the genus Pyemotes (Acariformes, Pyemotidae) associated with bark beetles (Coleoptera, Scolytidae) in Crimea. Zoologicheskii Zhurnal, 77: 1419-1424.

Khaustov, A.A. 1999. Redescription of $<$ Pediculoides $>$ ipidarius Redikortsev, 1947, and a description of a new species from the genus Paracarophenax (Acari: Heterostigmata: Acarophenacidae). Acarina, 7: 57-59.

Khaustov, A.A. 2000a. Mites of the family Winterschmidtiidae (Acari, Astigmata), associated with bark beetles (Coleoptera, Scolytidae) in Crimea. Vestnik Zoologii Supplement, 14: 50-59.

Khaustov, A.A. 2000b. Mites of the genus Elattoma (Acariformes, Pygmephoridae) from Crimea and North-West Russia. Vestnik Zoologii, 34: 77-83, 134.

Khaustov, A.A. 2008. Mites of the Family Scutacaridae of Eastern Palaearctic. Akademperiodika, Kiev. $290 \mathrm{pp}$.

Khaustov, A.A. 2017a. Anew species and a new record of mite genus Coleopygmephorus (Acari: Neopygmephoridae) associated with bark beetles (Coleoptera: Curculionidae: Scolytinae) from Russia. International Journal of Acarology, 43: 351-358.

Khaustov, A.A. 2017b. A new species and new records of pygmephoroid mites (Acari: Scutacaridae, Neopygmephoridae, Pygmephoridae) associated with Ips typographus (Coleoptera: Curculionidae: Scolytinae) from Western Siberia, Russia. International Journal of Acarology, 43: 594-602.

Khaustov, A.A. 2017c. A new species of Dolichocybe (Acari: Dolichocybidae) from Western Siberia, Russia. Systematic and Applied Acarology, 22: 1678-1687.

Khaustov, A.A. 2017d. A new species of Tarsonemus (Acari: Tarsonemidae) associated with the bark beetle, Polygraphus proximus (Coleoptera: Curculionidae: Scolytinae) from the Far East of Russia. Acarologia, 57: 673-687.

Khaustov, A.A. 2018. First record of the genus Microdispodides (Acari: Heterostigmata: Pygmephoridae) in Palaearctic, with description of a new species from Western Siberia, Russia. Systematic and Applied Acarology, 23: 441-448.

Khaustov, A.A., Tolstikov, A.V. and Ermilov, S.G. 2017. Parasitoid mites (Acari: Heterostigmata) of bark beetles (Coleoptera: Curculionidae: Scolytinae) of 
Western Siberia. Abstract book of the third International Persian Congress of Acarology, 23-25 August 2017: 23-24.

Khaustov, A.A., Trach, V.A. and Bobylev, A.N. 2016. Mites (Acari) phoretic on six-toothed spruce bark beetle, Pityogenes chalcographus Linnaeus (Coleoptera: Curculionidae: Scolytinae), in Western Siberia, Russia. Acarina, 24: 137-151.

Kiełczewski, B., Moser, J.C. and Wiśniewski, J. 1983. Surveying the acarofauna associated with Polish Scolytidae. Bulletin de la Société des Amis des Sciences et des Lettres de Poznan, Série D, 22: 151-159.

Kiełczewski, B. and Wiśniewski, J. 1971. Fauna roztoczy na mrówkach w Nadleśnictwie Doświadczalnym Zielonka. Prace Komisji Nauk Rolniczych i Komisji Nauk Leśnych, 32: 51-55.

Kiełczewski, B. and Wiśniewski, J. 1980. Bark beetle acarofauna in different types of forest habitat. Part III. Tarsonemini, Prostigmata, Acaridiae. Bulletin de la Société des Amis des Sciences et des Lettres de Poznań, Série D Sciences Biologiques, 20: 161-175.

Kiełczewski, B. and Wiśniewski, J. 1983. Bark beetle acarofauna in different types of forest habitat. I, II. Introduction and Mesostigmata. Folia Forestalia Polonica. Seria A. Leśnictwo, 25: 129-162.

Kinn, D.N. 1967. Notes on the life cycle and habits of Digamasellus quadrisetus (Mesostigmata: Digamasellidae). Annals of the Entomological Society of America, 60: 862-865.

Kinn, D.N. 1968. A new species of Pleuronectocelaeno (Acarina. Celaenopsidae) associated with bark beetles in North and Central America. Acarologia, 10: 191-205.

Kinn, D.N. 1991. A new Pleuronectocelaeno (Acari: Celaenopsidae) from Japan, with remarks on North American and European species. International Journal of Acarology, 17: 103-105.

Kinn, D.N. and Swanston, D.N. 1976. Key to mites commonly associated with the southern pine beetle. New Orleans, LA, Dept of Agriculture, Forest Service, Southern Forest Experiment Station. $11 \mathrm{pp}$.

Kirisits, T. 1998. Pathogenicity of three blue-stain fungi associated with the bark beetle Ips typographus to Norway spruce in Austria. Österreichische Zeitschrift für Pilzkunde, 7: 191-201.

Klimov, P.B. 1997. New data on the fauna and biology of acarid mites (Acari, Acaridae) from the Far East. Acarina, 5: 69-72.

Klimov, P.B. 1998a. Review of the genus Boletoglyphus (Acariformes, Acaridae). Zoologicheskii Zhurnal, 77: 1121-1127.
Klimov, P.B. 1998b. To the knowledge of acarid mites of the genus Schwiebea (Acariformes, Acaridae) from the Far East, with notes on systematic of the genus. Vestnik Zoologii, 32: 13-30.

Klimov, P.B. and Khaustov, A.A. 2018. A review of acarid mites (Acariformes: Acaridae) associated with bark beetles (Coleoptera: Curculionidae: Scolytinae), with description of Ipsoglyphus bochkovi gen. and sp. nov. Systematic \& Applied Acarology, 23: 1-26.

Klimov, P.B., OConnor, B.M., Ochoa, R., Bauchan, G.R. and Scher, J. 2016. Bee Mite ID: Bee-Associated Mite Genera of the World. USDA APHIS Identification Technology Program (ITP), Fort Collins, CO. Accessed 23 Mar 2018. http://idtools. org/id/mites/beemites/factsheet.php?name $=15324$

Klimov, P.B. and Tolstikov, A.V. 2011. Acaroid mites of Northern and Eastern Asia (Acari: Acaroidea). Acarina, 19: 252-264.

Knee, W., Forbes, M.R. and Beaulieu, F. 2013. Diversity and host use of mites (Acari: Mesostigmata, Oribatida) phoretic on bark beetles (Coleoptera: Scolytinae): Global generalists, local specialists? Annals of the Entomological Society of America, 106: 339-350.

Kofler, A. and Schmölzer, K. 2000. Zur Kenntnis phoretischer Milben und ihrer Tragwirte in Österreich (Acarina: Gamasina, Uropodina). Berichte des Naturwissenschaftlich-Medizinischen Vereins in Innsbruck, 87: 133-157.

Krause, A. 1917 (1919). Eine neue Borkenkäfermilbe, Calvolia Kneissli m. von Orthotomicus laricis Fabr. Archiv für Naturgeschichte. Abteilung A, 83: 123-124.

Kršlak, B., Zach, P. and Kulfan, J. 2010. The role of Hylastes cunicularius Erichson (Coleoptera: Scolytidae) in transferring uropodine mites in a mountain spruce forest. Journal of Forest Science, 56: 258-264.

Kuhlmann, M. 1998. Nachweise mit Bienen und Wespen (Hymenoptera Aculeata) assoziierter Milben (Acari) und Fächerflügler (Strepsiptera). Linzer biologische Beiträge, 30: 69-80.

Kurosa, K. 2000. Mites associated with insects and small mammals in Oda-chô, Ehime Prefecture, southwest Japan. In: Odamiyama-no-ShizenHenshû-Iinkai and E. Yamamoto (Eds.). Nature of Odamiyama, Oda-chô, Ehime, pp. 897-946.

Laboulbène, A. 1852. M. Al. Laboulbène lit une note conlenant la desription d'un Acarus qui se développe très souvent sur les insectes, dans nos collections, et auquel il donne le nom d'A. entomophagus. Annales de la Société entomologique de France, 10: LIV. 
Laboulbène, A. and Robin, C. 1862. Description de l'Acarus (Tyroglyphus) entomophagus Laboulbène et observations anatomiques sur le genre Tyroglyphus. Annales de la Société entomologique de France, 2: 317-338.

Levieux, J., Lieutier, F., Moser, J.C. and Perry, T.J. 1989. Transportation of phytopathogenic fungi by the bark beetle Ips sexdentatus Boerner and associated mites. Journal of Applied Entomology, 108: $1-11$.

Li, C., Zhan, X., Sun, E., Zhao, J., Wang, H., He, J. et al. 2014. The density and species of mite breeding in stored products in China. Nutrición Hospitalaria, 31: 798-807.

Li, L.-S., Xuan, J.-Y. and Fan, Q.-H. 1992. Taxonomic investigation of food mites in Sichuan Province. Journal of Southwest Agricultural University, 14: 23-34.

Lieutier, F. 1978. Les acariens associes a Ips typographus et Ips sexdentatus (Coleoptera : Scolytidae) en region parisienne et les variations de leurs populations au cours du cycle annuel. Bulletin d'écologie, 9: 307-321.

Lignières, J.L.M. 1893. Étude zoologique et anatomique du Tyroglyphus malus et de sa nymphe hypopiale. Mémoires de la Société zoologique de France, 6: 5-15.

Lindquist, E.E. 1969. Review of Holarctic tarsonemid mites (Acarina: Prostigmata) parasitizing eggs of ipine bark beetles. Memoirs of the Entomological Society of Canada, 101: 5-111.

Lindquist, E.E. 1970a. Relationships between mites and insects in forest habitats. Canadian Entomologist, 102: 978-984.

Lindquist, E.E. 1970b. Review of the genus Heterotarsonemus (Acarina: Tarsonemidae). Canadian Entomologist, 102: 812-829.

Lindquist, E.E. 1971. New species of Ascidae (Acarina: Mesostigmata) associated with forest insect pests. Canadian Entomologist, 103: 919-942.

Lindquist, E.E. and Hunter, P.E. 1965. Some mites of the genus Proctolaelaps Berlese (Acarina: Blattisociidae) associated with forest insect pests. $\mathrm{Ca}$ nadian Entomologist, 97: 15-32.

Macfarlane, R.P. 2005. Mites associated with bumble bees (Bombus: Apidae) in New Zealand. Records of the Canterbury Museum, 19: 29-34.

Magowski, W.Ł. 2010. Schaarschmidtia, a new subgenus of the genus Tarsonemus Canestrini and Fanzago, 1876 (Acari: Heterostigmatina: Tarsonemidae) - a systematic review of the mite taxon associated with subcortical coleopteran insects, with notes on its host affiliation, ecology and bio- geography. Polish Journal of Entomology, 79: i-ii, $1-176$.

Magowski, W.Ł. and Khaustov, A.A. 2006. Two new species of Tarsonemus (Acari: Tarsonemidae) associated with bark beetles (Coleoptera: Scolytidae) from Crimea, Ukraine. Zootaxa, 1359: 31-55.

Magowski, W.Ł. and Moser, J.C. 2003. Redescription of Tarsonemus minimax and definition of its species-group in the genus Tarsonemus (Acari: Tarsonemidae) with descriptions of two new species. Annals of the Entomological Society of America, 96: 345-368.

Mahunka, S. 1961. Contributions to the tyroglyphid fauna of Hungary (Acari). Annales Universitatis Scientiarum Budapestinensis de Rolando Eötvös Nominatae. Sectio biologica, 4: 113-117.

Mahunka, S. 1968. Studies on the mite fauna of Hungary I. (Acari). Annales Historico-Naturales Musei Nationalis Hungarici, 60: 249-260.

Mahunka, S. 1970. Atkák V.—Acari V. Magyarország Állatvilága (Fauna Hungariae 101), 18: 1-76.

Mahunka, S. 1976a. New and incompletely known taxa from the families Acaridae and Anoetidae (Acari: Acarida). Acta Zoologica Hungarica, 22:303-326.

Mahunka, S. 1976b. Über einige an Histeriden (Coleoptera) lebende Anoetiden-Deutonymphen (Acari). Parasitologia Hungarica, 9: 97-104.

Mahunka, S. 1983. Data to the Acarida Fauna of the Hortobágy National Park (Acari). In: S. Mahunka (Ed.), The Fauna of the Hortobágy National Park II. Akadémiai Kiadó, Budapest, pp. 375-376.

Mahunka, S. and Moser, J.C. 1980. Scutacarus scolyti sp.n. a new scutacarid species (Acari: Tarsonemina) from Germany. Parasitologia Hungarica, 13: 99-102.

Mahunka, S. and Moser, J.C. 1982. New data to the knowledge of the tarsonemids (Acari) living on bark beetles. Parasitologia Hungarica, 14: 87-89.

Makarova, O.L. 2012. Gamasid mites (Parasitiformes, Mesostigmata) of the European Arctic and their distribution patterns. Zoologicheskii Zhurnal, 91: 907-927.

Marchenko, I.I. 2002. Faunistic review of free-living Gamasina mites (Acari, Mesostigmata) from Sakhalin and Kuril Islands. Euroasian Entomological Journal: 31-48.

Marchenko, I.I. 2012. Spatial-typological organization of the soil Gamasina mite (Acari, Mesostigmata) community of Northeastern Altai. Communication II. Contemporary Problems of Ecology, 5: 23-33.

Mašán, P. 1999. Mites (Acarina) associated with burying and carrion beetles (Coleoptera, Silphidae) and description of Poecilochirus mrciaki sp. n. (Meso- 
stigmata, Gamasina). Biologia (Bratislava), 54: $515-524$.

Mašán, P. 2001. Roztoče kohorty Uropodina (Acarina, Mesostigmata) Slovenska. Bratislava, Slovenské národné múzeum. $320 \mathrm{pp}$.

Maslov, A.D. 2010. Koroed-Tipograf i Usykhanie Elovykh Lesov. Moscow, Vserosiyskiy nauchnoissledovatelskiy institute lesovodstva I mekhanizatsii lesnogo khozyaystva. $138 \mathrm{pp}$.

Maslov, A.D. and Matusevich, L.S. 2008. [Mites' (Acari) role in the population dynamics of bark beetles (Coleoptera, Scolytidae)]. Lesnoy Vestnik, 1: 66-72. [In Russian]

Matthewman, W.G. and Pielon, D.P. 1971. Arthropods inhabiting the sporophores of Fomes fomentarius (Polyporaceae) in Gatineau Park, Quebec. Canadian Entomologist, 103: 775-847.

Mazzuco, R.M., Lebarbenchon, M.A., Moecke, E.H.S., Meyer, E., Spíndola-Batti, M.A., Fröde, T. et al. 2000. Anafilaxia por ingestão de ácaros de estocagem. Revista Brasileira de Alergia e Imunopatologia, 23: 189.

Mercado, J.E., Hofstetter, R.W., Reboletti, D.M. and Negron, J.F. 2014. Phoretic symbionts of the Mountain Pine Beetle (Dendroctonus ponderosae Hopkins). Forest Science, 60: 512-526.

Michael, A.D. 1885. Notes on the life-histories of some of the little-known Tyroglyphidae. Journal of the Royal Microscopical Society, 2: 19-32+Pl. III.

Michael, A.D. 1903. British Tyroglyphidae. Vol. 2. London, Ray Society. 1-183+plates i-xxxix. pp.

Michalski, J. and Ratajczak, E. 1989. Korniki (Coleoptera: Scolytidae) wraz z towarzyszącą im fauną w Górach Świętokrzyskich. Fragmenta Faunistica, 32: 279-318.

Moniez, R. 1892. Contribution à l'histoire naturelle du Tyroglyphus mycophagus Mégnin. Mémoires de la Société zoologique de France, 5: 584-601.

Moraza, M.L., Fernandez, M. and Jurc, M. 2013. Phoretic mites of the six-spined engraver beetle, Ips sexdentatus (Böerner, 1776) (Coleoptera, Scolytinae), on Pinus halepensis in Slovenia. International Journal of Acarology, 39: 597-599.

Moser, J.C. 1975. Mite predators of southern pine beetle. Annals of the Entomological Society of America, 68: 1113-1116.

Moser, J.C. and Bogenschütz, H. 1984. A key to the mites associated with flying Ips typographus in South Germany. Zeitschrift Fur Angewandte Entomologie-Journal of Applied Entomology, 97: 437-450.

Moser, J.C., Eidmann, H.H. and Regnander, J.R. 1989. The mites associated with Ips typographus in Sweden. Annales Entomologici Fennici, 55: 23-27.
Moser, J.C., Perry, T.J. and Furuta, K. 1997. Phoretic mites and their hyperphoretic fungi associated with flying Ips typographus japonicus Niijima (Col., Scolytidae) in Japan. Journal of Applied Entomology, 121: 425-428.

Moser, J.C., Perry, T.J. and Solheim, H. 1989. Ascospores hyperphoretic on mites associated with Ips typographus. Mycological Research, 93: 513-517.

Moser, J.C. and Roton, L. M. 1971. Mites associated with southern pine bark beetles in Allen Parish, Louisiana. Canadian Entomologist, 103: 17751798.

Mullen, G.R., Leprince, D.J. and OConnor, B.M. 1989. Acarine associates of horse flies and deer flies (Diptera: Tabanidae) in North America. In: Progress in Acarology. Volume 2. Oxford \& IBH Publishing Co. Pvt. Ltd, New Delhi, pp. 291-296.

Müller, J. 1859 (1860). Insectenepizoen der mährischen Fauna. 157-184.

Musken, H., Franz, J.T., Wahl, R., Paap, A., Cromwell, O., Masuch, G. et al. 2000. Sensitization to different mite species in German farmers: clinical aspects. Journal of Investigational Allergology and Clinical Immunology, 10: 346-351.

Nachev, P.D. and Trenchev, G. 1987. The acarofauna associated with some Coccidae in Bulgaria. Pochvoznanie, Agrokhimiya i Rastitelna Zashchita, 22: 81-86.

Newstead, R. and Morris , H.M. 1920. Bionomic, morphological and economic report on the acarids of stored Grain and Flour-part II. Royal Society Reports on Grain Pests (War) Committee, 8: 4-15+Pl. I-V.

OConnor, B.M. 1982. Evolutionary ecology of astigmatid mites. Annual Review of Entomology: 385-409.

OConnor, B.M. 1989. Systematics, ecology and host associations of Naiadacarus (Acari: Acaridae) in the Great Lakes region. Great Lakes Entomologist, 22: 79-94.

OConnor, B.M. 1991. A preliminary report on the arthropod-associated astigmatid mites (Acari: Acariformes) of the Huron Mountains of Northern Michigan. Michigan Academician, 24: 307-320.

OConnor, B.M. and Houck, M.A. 1989. Two new genera of Hemisarcoptidae (Acari: Astigmata) from the Huron Mountains of northern Michigan. Great Lakes Entomologist, 22: 1-10.

OConnor, B.M. and Pfaffenberger, G.S. 1987. Systematics and evolution of the genus Paraceroglyphus and related taxa (Acari: Acaridae) associated with fleas (Insecta: Siphonaptera). Journal of Parasitology, 73: 1189-1197. 
Okabe, K. and OConnor, B.M. 2001. A method for both mass and individual rearing of fungivorous astigmatid mites (Acari). Experimental and Applied Acarology, 25: 493-504.

Olsen, A.R. 1983. Food-contaminating mites from imported foods entering the united states through southern California. International Journal of Acarology, 9: 189-193.

Oshima, S. 1977. Acaroid mites of house dust. In: M. Sasa and J. Aoki (Eds.). Contributions to Acarology in Japan. Zukan-no-Hokuryukan, Tokyo, pp. 525-568.

Ostovan, H., Miri, M. and Beyzavi, G. 2010. The first report of the genus Cercoleipus and family Cercomegistidae (Acari: Mesostigmata) from Iran. Plant Protection Journal, 2: 145-151. [In Persian]

Oudemans, A.C. 1901. Notes on Acari: Third series. Tijdschrift der Nederlandsche Dierkundige Vereeniging. Leiden, 7: 50-87+plates i-iii.

Oudemans, A.C. 1903. Notes on Acari: Sixth Series. Tijdschrift voor Entomologie, 46: 1-24.

Oudemans, A.C. 1906. Acarologische Aanteekeningen XXV. Entomologische Berichten, 2: 121-123.

Oudemans, A.C. 1907. Nachtrag zur Milben-Fauna der Umgegend Bremens. Abhandlungen herausgegeben vom Naturwissenschaftlichen Verein zu Bremen, 19: 48-67+Taf. II (Pope, C.A.: p 47).

Oudemans, A.C. 1919. Acarologische Aanteekeningen XXXVIII. Entomologische Berichten, 3: 183-191.

Oudemans, A.C. 1924. Acarologische Aanteekehingen LXXVII. Entomologische Berichten (Amsterdam), 6: 317-336.

Oudemans, A.C. 1928. Fauna Buruana Acari. Treubia, 7: $37-100$.

Oudemans, A.C. 1939. Neue Funde auf dem Gebiete der Systematik und der Nomenclatur der Acari. VII. Zoologischer Anzeiger Leipzig, 127: 184-190.

Penttinen, R., Viiri, H. and Moser, J.C. 2013. The mites (Acari) associated with bark beetles in the Koli national park in Finland. Acarologia, 53: 3-15.

Pernek, M., Hrasovec, B., Matošević, D., Pilaš, I., Kirisits, T. and Moser, J. 2008. Phoretic mites of three bark beetles (Pityokteines spp.) on Silver fir. Journal of Pest Science, 81: 35-42.

Pernek, M., Wirth, S.F., Blomquist, S.R., Avtzis, D.N. and Moser, J.C. 2012. New associations of phoretic mites on Pityokteines curvidens (Coleoptera, Curculionidae, Scolytinae). Central European Journal of Biology, 7: 63-68.

Pfammatter, J.A., Coyle, D.R., Gandhi, K.J.K., Hernandez, N., Hofstetter, R.W., Moser, J.C. et al. 2016. Structure of phoretic mite assemblages across subcortical beetle species at a regional scale. Environmental Entomology, 45: 53-65.
Pfammatter, J.A., Moser, J.C. and Raffa, K.F. 2013. Mites phoretic on Ips pini (Coleoptera: Curculionidae: Scolytinae) in Wisconsin red pine stands. Annals of the Entomological Society of America, 106: 204-213.

Philips, J.R. 2009. The mite (Acarina) fauna of trogid beetles (Coleoptera: Trogidae). International Journal of Acarology, 35: 1-17.

Pielou, D.P. and Verma, A.N. 1968. The arthropod fauna associated with the birch bracket fungus, Polyporus betulinus, in eastern Canada. Canadian Entomologist, 100: 1179-1199.

Plumari, M. 2008. Specie di Celaenopsidae, Parasitidae, Digamasellidae e Ascidae nuove per l'Italia (Acarina Mesostigmata). Bollettino della Societa Entomologica Italiana, 140: 75-90.

Poliță, D., Manu, M. and Marcu, V.M. 2016. Relationship among phoretic mites and Norway spruce bark beetles-Ips typographus and Pityogenes chalcographus. Revista Pădurilor, 131: 57-65.

Reck, G.F. 1976. Katalog Akarofauny Gruzinskoy SSR [=Catalogue of the acarofauna of the Georgian SSR]. Tbilisi, Metsniereba. $127 \mathrm{pp}$.

Redikortzev, V.V. 1947. [The mite Pediculoides ipidarius sp. n. (Acari: Pediculoididae), a parasite of bark beetles]. Entomologicheskoe Obozrenie, 29: 247-249. [In Russian]

Ripka, G., Fain, A. and Bolland, H.R. 1999. New data to the knowledge on the corticolous mite fauna in Hungary (Acari: Prostigmata, Astigmata, Oribatida). Acta Phytopathologica et Entomologica Hungarica, 34: 363-371.

Ripka, G. and Szabo, A. 2010. Additional data to the knowledge of the mite fauna of Hungary (Acari: Mesostigmata, Prostigmata and Astigmata). Acta Phytopathologica et Entomologica Hungarica, 45: 373-381.

Salmane, I. 2001. A check-list of Latvian Gamasina mites (Acari, Mesostigmata) with short notes to their ecology. Latvijas Entomologs, 38: 27-38.

Salmane, I. 2005. List of Mesostigmata mites (Acari, Parasitiformes) associated with Aphyllophorales fungi (Basidiomycetes) in Latvia. Latvijas Entomologs, 42: 45-57.

Salmane, I. 2006. New Mesostigmata (Acari, Parasitiformes) species in the fauna of Latvia. Latvijas Entomologs, 43: 52-56.

Salmane, I. 2007. Mesostigmata mite (Acari, Parasitiformes) fauna of wood-related microhabitats in Latvia. Latvijas entomologs, 44: 69-86.

Salmane, I. and Telnov, D. 2009. Mesostigmata mites (Acari: Parasitiformes) associated with beetles (Insecta: Coleoptera) in Latvia. Latvijas Entomologs, 47: 58-70. 
Samšiňák, K. 1956. Roztoci (Acari) na mouse Laphria flava L. Věstník Československé společnosti zoologické, 20: 353-357.

Samšiňák, K. 1957. Einige Bemerkungen zur Faunistik der in Gesellschaft von Insekten lebenden Acari. Acta faunistica entomologica Musei Nationalis Pragae, 2: 109-114.

Samšiňák, K. 1958. Einige neue Acariden-Deutonymphen als Commensalen der Insekten (Acari). Časopis Československé společnosti entomologické, 55: 289-295.

Samšiňák, K. 1960. Über einige forstwirtschaftlich wichtige Milben der Gattung Proctolaelaps Berlese 1923. Československá Parasilogie, 7: 297-307.

Samšiňák, K. 1962. Beiträge zur Kenntnis der Familie Anoetidae (Acari). Časopis Československé společnosti entomologické, 59: 87-97.

Samšiňák, K. and Vobrázková, E. 1983. Mites from the city pavement. Věstnik Československé Zoologické Společnosti, 47: 118-121.

Schaarschmidt, L. 1959. Systematik und Ökologie der Tarsonemiden. In: H.-J. Stammer (Ed.). Beiträge zur Systematik und Ökologie mitteleuropäischer Acarina. Vol. 1, part 2. Akademische verlagsgesellschaft Geest, Portig K.G., Leipzig, pp. 713-823.

Scheucher, R. 1957. Systematik und Ökologie der deutschen Anoetinen. In: H.-J. Stammer (Ed.). Beiträge zur Systematik und Ökologie mitteleuropäischer Acarina. Vol. 1, pp. 233-384.

Schweizer, J. 1949. Die Landmilben des schweizerischen Nationalparkes. 1. Teil. Parasitiformes Reuter 1909. Ergebnisse der wissenschaftlichen Untersuchungen im Schweizerischen Nationalpark. Heft 21. Band || (Neue Folge). Lüdin, Liestal. 1-99 pp.

Sellnick, M. 1951. Pleuronectocelaeno austriaca (Vitzthum) und P. africana sp. nov. (Acari). Entomologisk Tidskrift, 72: 184-194.

Sevastianov, V.D. 1969. A new myrmecophilous mite Divilia oculata gen. et sp.n. (Sarcoptiformes, Saproglyphidae). Zoologicheskii Zhurnal, 48: 447-449.

Sevastianov, V.D. 1970. Acarofauna of the forest ant Formica rufa L. In: I.S. Eytminavichyute (Ed.). Oribatidy i ikh rol' v pochvoobrazovatelnykh protsessakh. Institute of Zoology and Parasitology, Lithuanian SSR Academy of Sciences, Vilnius pp. 143-147.

Sevastianov, V.D. 1983. New species of the genus Scutacarus (Trombidiformes, Scutaridae). Zoologicheskii Zhurnal, 62: 1487-1496.

Shcherbak, G.I. 1980. Kleshchi semeystva Rhodacaridae Palearktiki [Mites of the family Rhodacaridae of the Palaearctic]. Naukova Dumka, Kiev. 215 pp.

Shcherbak, G.I. and Balan, P.G. 1982. Gamasid mites from the sand martin nests of the Central Forest
Steppe of the Ukrainian SSR. Vestnik Zoologii, 1982: 12-19. [In Russian]

Simoni, S., Nannelli, R., Roversi, P.F., Turchetti, T. and Bouneb, M. 2014. Thyreophagus corticalis as a vector of hypovirulence in Cryphonectria parasitica in chestnut stands. Experimental and Applied Acarology, 62: 363-375.

Sinha, R.N. 1964. Mites of stored grain in Western Canada - ecology and methods of survey. Proceedings of the Entomological Society of Manitoba, 20: 19-33.

Skorupski, M. and Gwiazdowicz, D.J. 1996. Roztocze (Acari, Mesostigmata) Pienin. Fragmenta Faunistica (Warsaw), 39: 223-243.

Smiley, R.L. 1969. Further studies on the Tarsonemidae 2. (Acarina). Proceedings of the Entomological Society of Washington, 71: 218-229.

Smiley, R.L. and Moser, J.C. 1970. Three cheyletids found with pine bark beetles (Acarina: Cheyletidae). Proceedings of the Entomological Society of Washington, 72: 229-235.

Smiley, R.L. and Moser, J.C. 1985. A new species, key to females, and distribution records for Heterotarsonemus (Acari: Tarsonemidae). International Journal of Acarology, 11: 247-253.

Stephen, F.M. and Kinn, D.N. 1980. Spatial distribution of mite associates of within-tree populations of Dendroctonus frontalis Zimm. Environmental Entomology, 9: 713-715.

Summers, F.M. and Price, D.W. 1970. Review of the mite family Cheyletidae. University of California Publications in Entomology, 61: 1-153.

Takov, D., Pilarska, D. and Moser, J. 2009. Phoretic mites associated with spruce bark beetle Ips typographus L. (Curculionidae: Scolytinae) from Bulgaria. Acta Zoologica Bulgarica, 61:293-296.

Tichomirov, S.I. 1977. Family Parasitidae. In: M.S. Gilarov and N.G. Bregetova (Eds.). Opredelitel' obytayshchikh v pochve kleshchey Mesostigmata [Identification key to soil-inhabiting mites Mesostigmata]. Nauka, Leningrad, pp. 55-107. [In Russian]

Trach, V.A. and Khaustov, A.A. 2017a. Redescription of adults and description of juvenile stages of bark beetle-associated mite Cercoleipus kuznetsovi Khaustov, 1997 (Acari: Mesostigmata: Cercomegistidae). Systematic and Applied Acarology, 22: 1733-1747.

Trach, V.A. and Khaustov, A.A. 2017b. Mites of the genus Proctolaelaps Berlese, 1923 (Acari: Mesostigmata: Melicharidae) associated with bark beetles in Asian Russia. Acarina, 25: 151-163.

Tseng, Y.H. 1989. Redescription of Tyrophagus kentinus Tseng, Tyrophagus bambusae Tseng and Aleu- 
roglyphagus formosanus Tseng and describes a new record species Rhizoglyphus canadii Manson. Chinese Journal of Entomology, Special Publication, 3: 37-50.

Türk, E. and Türk, F. 1957. Systematik und Ökologie der Tyroglyphiden Mitteleuropas. In: H.-J. Stammer (Ed.). Beiträge zur Systematik und Ökologie mitteleuropäischer Acarina. Band 1. Tyroglyphidae und Tarsonemini. Akademische Verlagsgesellschaft Geest \& Portig K.-G., Leipzig, pp. 4-384.

Turk, F.A. and Turk, S.M. 1952. LV.-Studies of Acari. $-7^{\text {th }}$ series: "Records and descriptions of mites new to the British fauna, together with short notes on the biology of sundry species". Annals and Magazine of Natural History, 5: 475-506.

Vissa, S. and Hofstetter, R.W. 2017. The role of mites in bark and ambrosia beetle-fungal interactions. In: V. Shields (Ed.). Insect Physiology and Ecology. InTech, Rijeka, pp. 135-156.

Vitzthum, H. 1926. Acari als Commensalen von Ipiden (Der Acarologischen Beobachtungen 11. Reihe). Zoologische Jahrbücher. Abteilung für Systematik, Ökologie und Geographie der Tiere, 52: 407-503.

Volgin, V.I. 1953. [Two new species of acaroid mites (Acarina, Acaroidea) of the fauna of the USSR]. Entomologicheskoe Obozrenie, 33: 262-265.

Volgin, V.I. 1965. [Two new species of acaroid mites (Acarina, Acaroidea) of the fauna of the USSR]. Entomologicheskoe Obozrenie, 44: 203-211.

Vrabec, M., Kalúz, S. and Ferenčík, J. 2012. Foretické roztoče na lykožrútovi smrekovom (Ips typographus) na vybraných lokalitách vo Vysokých Tatrách. Entomofauna Carpathica, 24: 1-14.

Walter, D.E. 1987. Life history, trophic behavior, and description of Gamasellodes vermivorax n.sp. (Mesostigmata: Ascidae), a predator of nematodes and arthropods in semiarid grassland soils. Canadian Journal of Zoology, 65: 1689-1695.

Walter, D.E. and Krantz, G.W. 2009. Collection, rearing, and preparing specimens. In: G.W. Krantz and D.E. Walter (Eds.). A Manual of Acarology. Third Edition. Lubbock (Texas), Texas Tech University Press, pp. 83-96.

Walter, D.E. and Latonas, S. 2012. Almanac of Alberta Acari Part II. Ver. 2.1. Edmonton, AB, The Royal Alberta Museum. 159 pp. http://www.royalalbertamuseum.ca/natural/insects/research/research.htm

Wasmann, E. 1897. Über einige myrmecophile Acarinen. I. Zoologischer Anzeiger, 20: 170-173.

Wasylik, A. 1959. Mite fauna (Tyroglyphoidea) in the nests of the common sparrow (Passer domesticus L.). Ekologia Polska. Seria B, 5: 187-190.
Westerboer, I. 1963. Die Familie Podocinidae Berlese 1916. In: H.-J. Stammer (Ed.). Beiträge zur Systematik und Ökologie Mitteleuropäischer Acarina. Band II. Mesostigmata 1. Akademische Verlagsgesellschaft Geest \& Portig K.-G., Leipzig, pp. 179-450.

Wirth, S.F. 2016. Description of developmental instars of Bonomoia sibirica sp.n. (Astigmata: Histiostomatidae) with ecological observations and phylogenetic conclusions. Acarina, 24: 97-111.

Wirth, S.F. and Garonna, A.P. 2015. Histiostoma ovalis (Histiostomatidae, Acari) associated with Ips sexdentatus (Scolytinae, Curculionidae, Coleoptera): ecology and mite redescription on the basis of formerly unknown adults and nymphs. International Journal of Acarology, 41: 415-428.

Wirth, S.F. and Pernek, M. 2012. First record of the mite Histiostoma ulmi in silver fir and indication of a possible phoretic dispersal by the longhorn beetle Acanthocinus reticulatus. Šumarski List, 136: 597-603.

Wirth, S.F., Weis, O. and Pernek, M. 2016. Comparison of phoretic mites associated with bark beetles Ips typographus and Ips cembrae from Central Croatia. Šumarski List, 140: 549-560.

Womersley, H. 1941. Studies in Australian Acarina. (2) Tyroglyphidae (s. 1.). Records of the South Australian Museum, 6: 451-488.

Woodring, J.P. and Moser, J.C. 1970. Six new species of anoetid mites associated with North American Scolytidae. The Canadian Entomologist, 102: 1237-1257.

Woodroffe, G.E. 1953. An ecological study of the insects and mites in the nests of certain birds in Britain. Bulletin of Entomological Research London, 44: 739-772.

Wurst, E. 2002. Beitrag zur Revision der mitteleuropäischen Arten der Gattung Schwiebea Oudemans, 1916 (Acari: Acaridae). Verlag Grauer, Beuren and Stuttgart. 128 pp. + plates.

Wurst, E. 2006. Limnic Acaridida (Astigmata). In: R. Gerecke (Ed.). Süßwasserfauna von Mitteleuropa, Vol. 7/2-1 Chelicerata:Araneae/Acari I. Süßwasserfauna von Mitteleuropa. Springer Spektrum, Berlin and Heidelberg, pp. 38-88.

Wurst, E. and Frank, B. 1998. Contributions to a revision of the genus Schwiebea (Acari: Acaridae). 1. Redescription of Schwiebea talpa and Schwiebea nesbitti. Stuttgarter Beitraege zur Naturkunde Serie A (Biologie), 579: 1-52.

Zach, P., Kršiak, B., Kulfan, J., Parák, M. and Kontschán, J. 2016. Mites Trichouropoda and 
Uroobovella spp. (Uropodoidea) phoretic on bark beetles (Scolytinae): a comparison from a declining mountain spruce forest in Central Europe. International Journal of Acarology, 42: 212-217.

Zamec, R. 2013. Soil astigmatine (Acari: Astigmatina) mites from birds' nests in Slovakia. Acta Societatis Zoologicae Bohemicae, 77: 165-172
Zachvatkin, A.A. 1941. Tiroglifoidnye kleshchi Tyroglyphoidea [=Tyroglyphoid mites Tyroglyphoidea]. In: S.A. Zernov (Ed). Fauna SSSR: Paukoobraznuye. Akademiya Nauk SSSR, Moscow-Leningrad, p. 475.

Ždárková, E. 1967. Stored food mites in Czechoslovakia. Journal of Stored Products Research, 3: 155-175.

Table 1

Abundance of mites phoretic on Ips typographus collected by pheromone traps in Western Siberia

\begin{tabular}{|c|c|c|c|c|}
\hline № & Mite species and phoretic stage & Location on beetle & $\begin{array}{l}\text { Total number } \\
\text { of phoretic mites }\end{array}$ & $\begin{array}{l}\text { Percent of total } \\
\text { mites found } \\
(\mathrm{n}=\mathbf{2 0 , 9 6 6 )}\end{array}$ \\
\hline 1 & $\begin{array}{l}\text { Trichouropoda polytricha } \\
\text { Deutonymph }\end{array}$ & $\begin{array}{l}\text { Mainly on abdomen, between } \\
\text { legs }\end{array}$ & 1,706 & 8.13 \\
\hline 2 & $\begin{array}{l}\text { Trichouropoda karawaiewi } \\
\text { Deutonymph }\end{array}$ & Elytral declivity, thorax & 28 & 0.13 \\
\hline 3 & $\begin{array}{l}\text { Trichouropoda structura } \\
\text { Deutonymph }\end{array}$ & Elytral declivity, thorax & 2 & $<0.01$ \\
\hline 4 & $\begin{array}{l}\text { Uroobovella ipidis } \\
\text { Deutonymph }\end{array}$ & Elytral declivity, thorax & 2,729 & 13.01 \\
\hline 5 & $\begin{array}{l}\text { Schizosthetus sp. } \\
\text { Deutonymph }\end{array}$ & All body & 12 & 0.57 \\
\hline 6 & $\begin{array}{l}\text { Dendrolaelaps quadrisetus } \\
\text { Deutonymph }\end{array}$ & Elytral declivity, under elytra & 4,313 & 20.57 \\
\hline 7 & $\begin{array}{l}\text { Dendrolaelaps pini } \\
\text { Deutonymph }\end{array}$ & Unknown & 3 & 0.01 \\
\hline 8 & $\begin{array}{l}\text { Proctolaelaps fiseri } \\
\text { Female }\end{array}$ & All body & 5 & 0.02 \\
\hline 9 & $\begin{array}{l}\text { Gamasellodes tatricus } \\
\text { Female }\end{array}$ & Unknown & 1 & $<0.01$ \\
\hline 10 & $\begin{array}{l}\text { Ereynetes sp. } \\
\text { Female }\end{array}$ & All body & 13 & 0.06 \\
\hline 11 & $\begin{array}{l}\text { Mexacheles virginiensis } \\
\text { Female }\end{array}$ & Unknown & 1 & $<0.01$ \\
\hline 12 & $\begin{array}{l}\text { Dolichocybe sibiriensis } \\
\text { Female }\end{array}$ & Unknown & 3 & 0.01 \\
\hline 13 & $\begin{array}{l}\text { Pyemotes sp. } \\
\text { Female }\end{array}$ & Unknown & 1 & $<0.01$ \\
\hline 14 & $\begin{array}{l}\text { Aethiophenax ipidarius } \\
\text { Female }\end{array}$ & Between coxae of legs I and II & 21 & 0.10 \\
\hline 15 & $\begin{array}{l}\text { Microdispodides moseri } \\
\text { Female }\end{array}$ & Unknown & 2 & $<0.01$ \\
\hline 16 & $\begin{array}{l}\text { Elattoma crossi } \\
\text { Female }\end{array}$ & Between coxae of legs I and II & 63 & 0.30 \\
\hline
\end{tabular}


A.A. Khaustov, P.B. Klimov, V.A. Trach et al.

\begin{tabular}{|c|c|c|c|c|}
\hline 17 & $\begin{array}{l}\text { Coleopygmephorus bogenschutzi } \\
\text { Female }\end{array}$ & Unknown & 3 & 0.01 \\
\hline 18 & $\begin{array}{l}\text { Coleopygmephorus hylophilus } \\
\text { Female }\end{array}$ & Unknown & 34 & 0.16 \\
\hline 19 & $\begin{array}{l}\text { Coleopygmephorus typographus } \\
\text { Female }\end{array}$ & Unknown & 1 & $<0.01$ \\
\hline 20 & $\begin{array}{l}\text { Scutacarus pseudoplurisetus } \\
\text { Female }\end{array}$ & Unknown & 2 & $<0.01$ \\
\hline 21 & $\begin{array}{l}\text { Scutacarus scolyti } \\
\text { Female }\end{array}$ & Between coxae of legs I and II & 8 & 0.03 \\
\hline 22 & $\begin{array}{l}\text { Scutacarus muscocicola } \\
\text { Female }\end{array}$ & Unknown & 3 & 0.01 \\
\hline 23 & $\begin{array}{l}\text { Scutacarus palustris } \\
\text { Female }\end{array}$ & Unknown & 7 & 0.03 \\
\hline 24 & $\begin{array}{l}\text { Iponemus gaebleri } \\
\text { Female }\end{array}$ & Elytral declivity, under elytra & 1,871 & 8.92 \\
\hline 25 & $\begin{array}{l}\text { Tarsonemus striatus } \\
\text { Female }\end{array}$ & Unknown & 49 & 0.23 \\
\hline 26 & $\begin{array}{l}\text { Tarsonemus bistridentati } \\
\text { Female }\end{array}$ & Unknown & 2 & $<0.01$ \\
\hline 27 & $\begin{array}{l}\text { Tarsonemus typographi } \\
\text { Female }\end{array}$ & Unknown & 38 & 0.18 \\
\hline 28 & $\begin{array}{l}\text { Heterotarsonemus lindquisti } \\
\text { Female }\end{array}$ & Unknown & 2 & $<0.01$ \\
\hline 29 & $\begin{array}{l}\text { Siculobata leontonycha } \\
\text { Adults }\end{array}$ & Mainly on the head and thorax & 7,431 & 35.44 \\
\hline 30 & $\begin{array}{l}\text { Acarus sp. } \\
\text { Deutonymph }\end{array}$ & Unknown & 8 & 0.03 \\
\hline 31 & $\begin{array}{l}\text { Boletoglyphus boletophagi } \\
\text { Deutonymph }\end{array}$ & Unknown & 2 & $<0.01$ \\
\hline 32 & $\begin{array}{l}\text { Forcellinia wasmanni } \\
\text { Deutonymph }\end{array}$ & Unknown & 2 & $<0.01$ \\
\hline 33 & $\begin{array}{l}\text { Ipsoglyphus bochkovi } \\
\text { Deutonymph }\end{array}$ & Unknown & 38 & 0.18 \\
\hline 34 & $\begin{array}{l}\text { Kuzinia laevis } \\
\text { Deutonymph }\end{array}$ & Unknown & 4 & 0.01 \\
\hline 35 & $\begin{array}{l}\text { Naiadacarus sp. } \\
\text { Deutonymph }\end{array}$ & Unknown & 43 & 0.20 \\
\hline 36 & $\begin{array}{l}\text { Schwiebea sp. eurynympha-group } \\
\text { [punctate dorsum] } \\
\text { Deutonymph }\end{array}$ & Unknown & 1 & $<0.01$ \\
\hline 37 & $\begin{array}{l}\text { Schwiebea sp. [small, unsclerotized, } \\
1 a, 3 a \text { filiform] } \\
\text { Deutonymph }\end{array}$ & Unknown & 1 & $<0.01$ \\
\hline 38 & $\begin{array}{l}\text { Schwiebea nesbitti } \\
\text { Deutonymph }\end{array}$ & Unknown & 2 & $<0.01$ \\
\hline
\end{tabular}


Review of mites associated with Ips typographus

\begin{tabular}{|c|c|c|c|c|}
\hline 39 & $\begin{array}{l}\text { Schwiebea nova } \\
\text { Deutonymph }\end{array}$ & Unknown & 210 & 1.00 \\
\hline 40 & $\begin{array}{l}\text { Schwiebea sp.1 nova-group [two } \\
\text { tibial setae, regular attachment organ] } \\
\text { Deutonymph }\end{array}$ & Unknown & 33 & 0.15 \\
\hline 41 & $\begin{array}{l}\text { Schwiebea sp. nova-group [two tibial } \\
\text { setae, wide attachment organ] } \\
\text { Deutonymph }\end{array}$ & Unknown & 5 & 0.02 \\
\hline 42 & $\begin{array}{l}\text { Schwiebea sp. nova-group [granulate } \\
\text { dorsum, short legs III-IV] } \\
\text { Deutonymph }\end{array}$ & Unknown & 4 & 0.01 \\
\hline 43 & $\begin{array}{l}\text { Schwiebea scheucherae } \\
\text { Deutonymph }\end{array}$ & Unknown & 4 & 0.01 \\
\hline 44 & $\begin{array}{l}\text { Thyreophagus corticalis } \\
\text { Deutonymph }\end{array}$ & Unknown & 1 & $<0.01$ \\
\hline 45 & $\begin{array}{l}\text { Thyreophagus entomophagus } \\
\text { Deutonymph }\end{array}$ & Unknown & 2 & $<0.01$ \\
\hline 46 & $\begin{array}{l}\text { Thyreophagus aff. odyneri } \\
\text { Female }\end{array}$ & Unknown & 1 & $<0.01$ \\
\hline 47 & $\begin{array}{l}\text { Tyrophagus putrescentiae } \\
\text { Adults }\end{array}$ & Unknown & 1 & $<0.01$ \\
\hline 48 & $\begin{array}{l}\text { Divilia aff. occidentalis } \\
\text { Deutonymph }\end{array}$ & Unknown & 4 & 0.01 \\
\hline 49 & $\begin{array}{l}\text { Divilia sp. } \\
\text { Deutonymph }\end{array}$ & Unknown & 2 & $<0.01$ \\
\hline 50 & $\begin{array}{l}\text { Nanacarus sp. } 1 \\
\text { Deutonymph }\end{array}$ & Unknown & 3 & 0.01 \\
\hline 51 & $\begin{array}{l}\text { Nanacarus sp. } 2 \\
\text { Deutonymph }\end{array}$ & Unknown & 6 & 0.02 \\
\hline 52 & $\begin{array}{l}\text { Superioropus huronmontanus } \\
\text { Deutonymph }\end{array}$ & Unknown & 12 & 0.05 \\
\hline 53 & $\begin{array}{l}\text { Parawinterschmidtia kneissli } \\
\text { Deutonymph }\end{array}$ & Unknown & 7 & 0.03 \\
\hline 54 & $\begin{array}{l}\text { Saproglyphus aff. hagensis } \\
\text { Deutonymph }\end{array}$ & Unknown & 1 & $<0.01$ \\
\hline 55 & $\begin{array}{l}\text { Saproglyphus waldorfae } \\
\text { Deutonymph }\end{array}$ & Unknown & 1 & $<0.01$ \\
\hline 56 & $\begin{array}{l}\text { Histiostoma ovalis } \\
\text { Deutonymph }\end{array}$ & Unknown & 5 & 0.02 \\
\hline 57 & $\begin{array}{l}\text { Histiostoma piceae } \\
\text { Deutonymph }\end{array}$ & All body & 2,105 & 10.04 \\
\hline 58 & $\begin{array}{l}\text { Histiostoma pini } \\
\text { Deutonymph }\end{array}$ & Unknown & 100 & 0.47 \\
\hline 59 & $\begin{array}{l}\text { Probonomoia pini } \\
\text { Deutonymph }\end{array}$ & Unknown & 3 & 0.01 \\
\hline 60 & $\begin{array}{l}\text { Probonomoia sibirica } \\
\text { Deutonymph }\end{array}$ & Unknown & 1 & $<0.01$ \\
\hline
\end{tabular}

